\title{
CORPUS Corpus
}

Archivos virtuales de la alteridad americana

Vol. 7, No 2 | 2017

Julio / Diciembre 2017

\section{Los autos de ejecución de las sentencias del visitador Luján de Vargas a los encomenderos de Córdoba (1693-1694)}

The files of execution of the sentences of inspector Luján de Vargas to the encomenderos of Córdoba (1693-1694)

\section{Sonia Tell}

\section{OpenEdition}

\section{Journals}

\section{Electronic version}

URL: http://journals.openedition.org/corpusarchivos/1906

DOI: 10.4000/corpusarchivos.1906

ISSN: $1853-8037$

\section{Publisher}

Diego Escolar

\section{Electronic reference}

Sonia Tell, «Los autos de ejecución de las sentencias del visitador Luján de Vargas a los

encomenderos de Córdoba (1693-1694) », Corpus [En línea], Vol. 7, No 2 | 2017, Publicado el 20

diciembre 2017, consultado el 20 abril 2019. URL : http://journals.openedition.org/

corpusarchivos/1906; DOI : 10.4000/corpusarchivos.1906

This text was automatically generated on 20 April 2019

Licencia Creative Commons: Atribución-NoComercial 2.5 Argentina (CC BY-NC 2.5 AR) 


\title{
Los autos de ejecución de las sentencias del visitador Luján de Vargas a los encomenderos de Córdoba (1693-1694) ${ }^{1}$
}

\author{
The files of execution of the sentences of inspector Luján de Vargas to the \\ encomenderos of Córdoba (1693-1694)
}

Sonia Tell

\section{EDITOR'S NOTE}

Fecha de recepción del original: 06/13/2017

Fecha de aceptación para publicación: 27/11/2017

1 Entre 1692 y 1694, Antonio Martínez Luján de Vargas, oidor de la Real Audiencia de La Plata, realizó una visita a las encomiendas de todas las jurisdicciones de la Gobernación del Tucumán, habiendo transcurrido un extensísimo período desde la anterior visita general realizada por otro oidor de la misma Audiencia, Francisco de Alfaro, en 1611-1612. Con ello se concretó un pedido originalmente realizado en 1667 por el gobernador Alonso de Mercado y Villacorta a la por entonces existente Real Audiencia de Buenos Aires, sobre cuya necesidad insistieron otras autoridades posteriormente -particularmente el obispo del Tucumán Nicolás de Ulloa- quienes determinaron al rey a ordenar la visita en 1690 y comisionar su realización a Luján de Vargas, por entonces el oidor más antiguo de la Audiencia de La Plata (Doucet 1980b).

Desde la publicación de los estudios de Doucet (1980a, 1980b) se ha congregado un número de calificados investigadores en torno al estudio de esta visita, que ha investigado el proceso mismo de la inspección y la situación de las sociedades indígenas bajo el régimen de encomienda privada "de servicios personales" en la Gobernación del 
Tucumán, cuyos estudios pioneros debemos a Ana María Lorandi $(1988,1997)$, Gastón Doucet $(1986,1990)$ y Silvia Palomeque (2000). Gracias a este caudal de investigaciones, ${ }^{2}$ es conocido que entre los propósitos principales de la visita se contaron el desagravio de los indios encomendados mediante el pago, por parte de los vecinos feudatarios, de las deudas no saldadas que correspondían a "demasía de tasa", "trabajo concertado no retribuido" o "indemnizaciones por malos tratos de los encomenderos o sus agentes", así como el reconocimiento de la situación de las tierras comunales y capillas que debían tener todos los pueblos de indios, recordando en este sentido la vigencia de las Ordenanzas de Francisco de Alfaro de 1612 (Castro Olañeta 2015a, p. 19; 2017, p. 18).

3 Se Destaca el hecho de que es la primera inspección realizada y concluida por el oidor fuera la de Córdoba y que, precisamente en ese distrito, inmediatamente después de terminar los autos, Luján de Vargas dejara órdenes expresas de "ejecutar sus sentencias" contra los encomenderos y comisionara un juez con poder para hacerlo. En las demás jurisdicciones comisionó a autoridades locales para que dejaran testimonio en los cabildos de las sentencias y de los autos que el visitador dictó al finalizar la inspección de cada jurisdicción (Auto General y Auto de Doctrina), si bien no se ha confirmado si esto se hizo efectivo (Castro Olañeta 2015a, p. 51). En el caso de Santiago del Estero, se conserva el registro de las ejecuciones de sentencias relativas a deudas salariales (Farberman y Boixadós 2006).

4 La visita se estructura de manera uniforme: se presentan las preguntas por las cuales serán interrogados los indios encomendados (Memorial), sus declaraciones, el padrón de tributarios, la declaración del encomendero, los cargos contra él, su descargo, la sentencia y las costas. Las sentencias, que formalizan legalmente el castigo contra los encomenderos, constan de dos partes: el visitador señala una pena económica aplicada a reales cajas $\mathrm{y}$, por otra parte, obliga al encomendero a una “indemnización y/o restitución [que] implica el desagravio para con los indios gracias a la intervención del representante del poder regio". En este caso, se señala, "no se trata de un castigo al encomendero, sino de la aplicación de la ley real que lo obliga a pagar lo que adeuda y restituir las tierras que no son propias" (Castro Olañeta 2017, pp. 25-26). Son estas últimas las sentencias que el juez comisionado por Luján de Vargas antes de continuar su recorrido deberá ejecutar, es decir, garantizar su cumplimiento.

En el caso de Córdoba, cuya visita fue realizada por Luján de Vargas entre el 6 de noviembre de 1692 y el 19 de mayo de 1693, se dispone de los autos completos de las ejecuciones de sentencias, tanto las relativas a la adjudicación o ampliación de tierras de reducción, como al reconocimiento de capillas y el pago de deudas o indemnizaciones a los indios de encomienda por trabajo no remunerado. En este artículo se presenta la transcripción paleográfica de este último y extenso documento, una pieza excepcional en el contexto regional, precisamente por ser el único registro completo de las ejecuciones de sentencias del oidor para la gobernación hallado hasta el momento.

6 El juez comisionado para estas ejecuciones fue el capitán Manuel de Ceballos Neto y Estrada, alguacil mayor de la ciudad de Córdoba. El estudio detallado del recorrido y procedimientos seguidos por el alguacil en correspondencia con las instrucciones que le fueron dadas por Luján de Vargas ha sido efectuado por Castro Olañeta en dos publicaciones (2015a, 2015b), de las que se recuperan a continuación algunos aspectos sobresalientes.

7 Entre el 9 de septiembre de 1693 y el $1^{\circ}$ de abril de 1694, Ceballos recorrió personalmente, en compañía del protector de naturales Juan López de Fuenteseca, los lugares donde 
estaban asentadas las 24 encomiendas que debían inspeccionarse (algunas ya reducidas en pueblos de indios, otras todavía en tierras de sus encomenderos, situación esta última que era muy común). ${ }^{3}$ En 15 casos el alguacil controló o hizo efectivo el pago de deudas, en 17 la inspección sirvió para verificar la construcción o reconstrucción de capillas y en 16 para hacer el reconocimiento, mensura y asignación de las tierras de reducción (Castro Olañeta 2015b).

8 Los autos comienzan con la copia o traslado de la "Comisión" otorgada por Luján de Vargas a Ceballos, donde le expidió instrucciones precisas para calcular la superficie de tierras a adjudicar según el número de indios de encomienda y especificó los requisitos a cumplir en cuanto a calidad de las tierras, acceso al agua y distancia que debían guardar con la casa del encomendero. Cumpliendo con ellas, en algunos casos, Ceballos verificó la existencia de pueblos de reducción creados previamente, la presencia efectiva de los indios en ellos y la existencia de la capilla, ordenando, cuando fue necesario, el retorno a sus pueblos de los indios que todavía estaban en las propiedades de sus encomenderos y la reconstrucción de las capillas. En otros casos, el comisionado señaló, midió, amojonó y asignó tierras a aquellos indios que aún no tenían pueblo de reducción y residían en unidades productivas de sus encomenderos, ${ }^{4}$ fijando un plazo para la construcción de la capilla. Esta actuación se verificó particularmente con población desterrada de Valles Calchaquíes y del Chaco en las décadas previas que habían sido entregadas en encomienda a vecinos de Córdoba, pero también con originarios del territorio de la jurisdicción. Estas "intervenciones" han sido distinguidas por Castro Olañeta (2015b, p. 94) como orientadas, unas, a la reafirmación y consolidación de "derechos a la tierra que estaban en proceso de desaparición, en proceso de abandono o de traslado reciente", y otras a la creación de "nuevos derechos" a la tierra.

El registro detallado que hizo Ceballos de la unidad de medida, instrumentos de mensura y el procedimiento para realizar la medición en las distintas direcciones hasta "cuadrar" las tierras, los mojones colocados, las condiciones de los terrenos señalados para el cultivo y la presencia de fuentes de agua, respetó pautas habituales en la época para las operaciones de mensura de tierras. Similar procedimiento siguió en los casos en los que ordenó la ampliación de tierras previamente adjudicadas por los encomenderos, cuando éstas no tenían la extensión correspondiente al número de tributarios. Toda vez que pudo constatar que la capilla había sido construida, también hizo una descripción bastante detallada de las dimensiones, formas y materiales del edificio, el altar y la cruz.

Al final del proceso, exhortó a los vecinos feudatarios a otorgar "instrumento público" de las tierras asignadas a sus indios, ante el escribano del cabildo de Córdoba, requisito que Luján de Vargas había dispuesto en las instrucciones contenidas en la comisión. ${ }^{5}$ En la lista agregada al final de los autos figuran solo cinco de los quince feudatarios que debían cumplir con esta obligación y se desconoce si el resto lo hizo posteriormente.

11 La comisión expedida por Luján facultaba también a Ceballos a realizar el ajuste y liquidación de deudas pendientes de los encomenderos con los indios que le habían servido, sin hacer mayores especificaciones. En el registro de estas actuaciones el comisionado detalló los nombres de los indios e indias, el monto de la deuda calculado en unidad monetaria, la causa de la misma, los productos con los que se pagó y el índice utilizado para calcular su equivalencia monetaria.

12 Todas estas actuaciones, realizadas por Ceballos en compañía del protector de naturales, testigos $\mathrm{y}$-en los casos en que estuvieron presentes- encomendero, curaca o indios de la 
encomienda, conforman el contenido principal de los autos que aquí se presentan transcriptos.

El proceso de ejecución de las sentencias de la visita ha sido abordado en estudios previos. Algunos se han dedicado a la reconstrucción de dicho proceso como parte de una coyuntura política particular y significativa, como los ya citados de Castro Olañeta. Otros recuperan las sentencias dentro de un conjunto más amplio de fuentes para abordar la tenencia colectiva de la tierra por parte de la población indígena en Córdoba (González Navarro 2010) o para cartografiar las encomiendas y pueblos de reducción y sus procesos de persistencia, transformación y nominación a lo largo del período colonial (Tell y Castro Olañeta 2011, 2016). Finalmente, hay estudios de casos que incorporan sentencias específicas para abordar las apropiaciones del territorio indígena (Tell 2012; Schibli y Tell 2015) o los derroteros de la población desnaturalizada del Valle Calchaquí entregada en encomienda en Córdoba, que fue reducida en esta coyuntura (González Navarro 2015; Zelada 2017).

Sin duda, se trata de una fuente de gran importancia para la historia y la etnohistoria de Córdoba, que sigue ofreciendo posibilidades de consulta y entrecruzamiento. Al respecto y en conexión con los aportes de los estudios previos, quisiéramos destacar alternativas de lectura de este documento que consideramos significativas.

Una posibilidad procede de la inclusión de esta ejecución específica dentro de una reconstrucción y periodización más extensa de las políticas de la Corona entre los siglos XVI y XVII, orientadas al control de los encomenderos, las condiciones de otorgamiento o reotorgamiento de las encomiendas, la regulación de las formas de acceso a la fuerza de trabajo indígena en el marco de la encomienda de "servicios personales" y a la reparación de los agravios de los vecinos feudatarios sobre las sociedades indígenas. En los últimos años se está avanzando sobre esta línea, cuyos aportes están permitiendo matizar las tesis previas que enfatizaban el ejercicio discrecional y arbitrario del poder por parte de las autoridades locales y de los encomenderos en la Gobernación del Tucumán. ${ }^{6}$ Se trata de una de las facetas menos conocidas de la historia política de la jurisdicción y de la gobernación - de por sí, poco estudiada-, ene especial para la segunda mitad del siglo XVII y la primera del siglo XVIII, sobre la que todavía queda mucha investigación por realizar.

16 Una segunda posibilidad es la que presenta la lectura entrecruzada de la visita de Luján de Vargas y las ejecuciones de sus sentencias por Manuel de Ceballos como punto del proceso vivido por las sociedades originarias. Desde ese enfoque, Castro Olañeta (2015b, p. 86) ha demostrado que, a su paso, el visitador encontró una variedad de "situaciones o momentos de procesos diferenciados de las poblaciones encomendadas", tanto hacia la desestructuración como hacia la consolidación de pueblos de indios. El abanico, según la autora, comprendía desde pueblos de indios con tierras, autoridades étnicas y tributarios asentados, hasta pueblos en proceso avanzado de abandono de su asiento o desarticulación; desde indios asentados en las tierras privadas de sus encomenderos (algunos de los cuales recordaban sus pueblos de origen y otros no), hasta encomiendas que solo conservaban el nombre, ya sin tributarios, entre otras situaciones intermedias. La visita y las ejecuciones permiten reconstruir ese amplio rango de situaciones y las intervenciones de la Corona en la cartografía de las encomiendas. Su estudio, de este modo, contribuye a poner de relieve la complejidad y diversidad de los procesos atravesados por los pueblos sujetos a la encomienda privada en los siglos XVI y XVII, y las 
particularidades de una gobernación donde esa institución recién empezó a declinar iniciado el siglo XVIII y terminó de desaparecer a mediados de ese siglo.

Por último, otra posibilidad de lectura ofrece la contrastación de estos autos con fuentes más tardías -sobre todo expedientes judiciales y catastros- que permiten rastrear los derroteros posteriores de los derechos y títulos de tierras originados en estas ejecuciones. Cabe recordar que, en la jurisdicción de Córdoba, los derechos a tierras de reducción se originaron fundamentalmente en las visitas de Alfaro y Luján de Vargas y en asignaciones realizadas puntualmente por distintos gobernadores entre los siglos XVI y XVII. No hubo composiciones de tierras (situación que fue común a toda la Gobernación del Tucumán) y la compra de terrenos por parte de los pueblos de indios no fue una operación habitual: solo se cuenta hasta ahora con datos fehacientes de una sola compra de terrenos, muy tardía, efectuada por un grupo de naturales de Cosquín en 1817 (Tell 2011).

Como es conocido, no se han hallado los autos de la visita de Alfaro; el conocimiento de las asignaciones de tierras de reducción que hizo este oidor en la gobernación es parcial, fragmentario y obtenido por referencias en otros documentos (Albeck y Palomeque 2009). En el caso de Córdoba, pocos de los pueblos a los que Ceballos asignó o amplió tierras sobrevivieron en las siguientes décadas (Tell y Castro Olañeta 2011) pero, en aquellos que conservaron sus derechos en común, la intervención de 1694 operó de distintas maneras. Hasta ahora se pudo corroborar para un solo pueblo la conservación del original o de una copia de la demarcación efectuada por Manuel de Ceballos: San Marcos (denominado también San Jacinto en la documentación del siglo XVIII), encomendado a Alonso Luján de Medina en 1694. Hacia 1770-1772 el curaca todavía conservaba un papel "roto, sin firmas y casi ininteligible" que fue incluido en el expediente de un litigio por restitución de tierras del pueblo, iniciado contra los propietarios de la estancia vecina. En esos años, el deteriorado documento fue dado por "firme y subsistente" en la medida que el apoderado de la parte contraria admitió "en otro tiempo haver leido ya aquel documento bueno entero y en todo valedero" y que el original o traslado de los autos de Ceballos no se había hallado en el archivo del cabildo de Córdoba, según hicieron constar las justicias actuantes. ${ }^{8}$ Ese documento de dificultosa lectura, reinterpretado según los criterios de agrimensura de fines del siglo XVIII, fue la base para realizar un nuevo deslinde y amojonamiento de las tierras del pueblo en 1801, junto con otras fuentes de información -la memoria de los habitantes del pueblo, los vestigios de centros y mojones, la capilla y áreas de cultivos-, cuyo registro escrito aprobado por el virrey del Río de la Plata sería puesto en juego en repetidas ocasiones en el siglo XIX.

En otros casos, la asignación hecha por Ceballos era solo recordada un siglo después, como sucedió hacia 1800 cuando el pueblo de San Joseph (que en 1694 era encomienda de Cristóbal de Funes y Ludueña y cuyas tierras fueron ampliadas por Manuel de Ceballos) reclamaba en la Audiencia de Buenos Aires contra la inminente usurpación de sus tierras para trazar una villa a la vera del Río Segundo. Ambrosio Funes, cuyo informe fue solicitado por el fiscal de la Audiencia, hizo mención a las "diligencias practicadas por un alguacil mayor en calidad de juez de comision despachado por el señor doctor don Antonio Martinez..., en consorcio del capitan Juan Lopez de Fuenteseca, protector (supongo) de dichos indios". ${ }^{9}$ Sin embargo, la comunidad de San Joseph no contaba con una copia del auto ni de título alguno de sus tierras, Ambrosio Funes no mencionó que existiera una copia en el archivo familiar (él era descendiente de los primeros encomenderos de San Joseph) y dijo no haber tenido acceso al archivo del cabildo de Córdoba durante el litigio (Schibli y Tell 2015). ${ }^{10}$ Posiblemente esta fuera la situación en la 
mayoría de los pueblos a los que Ceballos adjudicó tierras y también de los que las recibieron en períodos previos de otras autoridades: que los vecinos feudatarios que debían extender escrituras de las tierras no lo hicieran o, de haberlo verificado, se quedaran con los títulos originales. Desde esa perspectiva, los autos de las ejecuciones de Ceballos, su conservación, pérdida u ocultamiento, se ubican como un jalón dentro de la memoria indígena del territorio y parte de la "compleja estratigrafía" de documentos que quedó sujeta a relecturas en los siglos posteriores, bajo nuevas aproximaciones técnicas al terreno y dentro de distintos sistemas legales (Rappaport 2005 [1994], p. 169). La mayoría de los casos de formación de pueblos de reducción en tierras comunales demarcadas por Ceballos aún no han sido estudiados. Su tratamiento, junto con otras fuentes que permitan rastrear a los pueblos que fueron reducidos en otros momentos, aportará a la reconstrucción de la estructura agraria de la región y, dentro de ella, a la tardía, problemática e incompleta separación de tierras indígenas y españolas que había sido proyectada por Alfaro, procesos que se conocen de manera fragmentaria o desigual para distintos momentos del período colonial y que aguardan un caudal de estudios sistemáticos.

\section{Características del manuscrito y criterios de transcripción}

El manuscrito se conserva en el Archivo y Biblioteca Nacionales de Bolivia, en el fondo Audiencia de Charcas, serie Expedientes Coloniales, con la signatura EC-1694-15. Consta de 99 folios rectos y versos, se encuentra completo y en muy buen estado de conservación. Se trata de una copia o traslado de los autos originales obrados por Manuel de Ceballos Neto y Estrada, cuyo original desconocemos si se conserva. La copia, realizada en papel común, fue protocolizada por el escribano público y de cabildo Luis Izquierdo de Guadalupe en Córdoba el 30 de abril de 1694, si bien escrita por amanuenses distintos, cuya identidad no se ha podido determinar. El documento se inicia con la Comisión hecha por el oidor Luján de Vargas en la persona de Manuel de Ceballos Neto y Estrada, seguida por la aceptación y juramento de este. A continuación, se registran las actuaciones del juez comisionado, en general en el orden cronológico en que fueron realizadas. Las anotaciones al margen izquierdo del documento indican el tipo de actuación: si se trató de señalamiento de tierras, reconocimiento de capillas, liquidación y ajuste de deudas u otras diligencias. El documento culmina con un "auto" de Ceballos recordando a los feudatarios la obligación de extender las escrituras de las tierras asignadas y la notificación del escribano de cabildo que menciona a aquellos que se presentaron a cumplir con esa obligación. Por último, se encuentra la rúbrica original del escribano de cabildo Luis Izquierdo de Guadalupe con la información sobre la copia realizada.

En este artículo se anexa la transcripción del documento completo. Se optó por una transcripción paleográfica literal modernizada del manuscrito, esto es, una transcripción fiel al original, en la que "todas las palabras se transcriben tal como aparecen, con la ortografía original, no cambian las letras, no se agrega ni omite nada" (Tanodi 2000, p. 262), pero se realizan algunos cambios mínimos para una lectura más ágil y accesible. Para ello, se observaron las Normas para la Transcripción de Documentos Históricos Panamericanos, aprobadas en la Primera Reunión Interamericana sobre Archivos celebrada en Washington en $1961 .{ }^{11}$ 

completando las omisiones de las letras. Se normalizó y redujo el uso de mayúsculas al mínimo, manteniéndolas o restituyéndolas solo para nombres propios e instituciones, dada la gran cantidad de mayúsculas superfluas según los criterios actuales. Se modificaron según la forma actual las separaciones y las uniones de palabras que iban en contra de la morfología de las mismas. Se respetó la grafía original del documento, se suprimieron signos de puntuación originales y se incorporaron nuevos cuando se consideró estrictamente necesario para facilitar la lectura y comprensión del texto. El cambio principal en este aspecto fue el reemplazo del signo = por punto o coma, según correspondiere. Las anotaciones efectuadas al margen o entre líneas por los amanuenses, los subrayados, palabras repetidas, tachadas o testadas, se aclararon entre corchetes. Las palabras que tenían errores o estaban incompletas, se transcribieron de la misma forma indicando [sic]. Aquellas palabras de interpretación dudosa se presentan seguidas por la forma [?].

Por tratarse la mayor parte del manuscrito de una copia (sólo el párrafo final contiene firmas originales), prácticamente no hay separaciones entre los distintos documentos que componen el auto. En la presentación de la transcripción se introdujeron estas separaciones utilizando las anotaciones realizadas por los amanuenses en el margen izquierdo a manera de títulos, a fin de facilitar la lectura y la ubicación de información, siempre conservando su ubicación original dentro del texto.

Finalmente, se respetó la foliación original, introducida por los mismos amanuenses, colocándose entre corchetes el número de folio y aclarando si es recto (r) o verso (v).

Transcripción del manuscrito

[1r] [Al margen: Comission]

En la ciudad de Cordova en cuatro dias del mes de mayo de mill y seiscientos y nobenta y tres años el señor dottor don Antonio Martinez Luxan de Vargas, del consejo de su magestad su oydor mas antiguo de la real audiencia de La Platta visittador general de esta provincia del Tuccuman por expecial comission de su majesttad etcetera. Dixo que tiene mandado a los mas de los encomenderos en las sentenzias de la visitta de los indios de ellos les asignen y señalen dentro de zierto termino tierras bastantes y sufizientes para que siembren y tengan sus ganados; assi para poderse sustentar como para pagar los tributtos de su obligazion y que esto sea con asistencia del protector general; e interbencion de la justicia hordinaria o persona que su merced nombrare y que ayan de hir a costa de dichos encomenderos a las estancias y haziendas donde esttan asitiados [1v] los indios cuyas sentenzias tienen consentidas, y por que no pudiendose de tener para este efecto estando acavada la visitta y de proximo para salir de estta ciudad dicho señor visitador en prosecuzion de lo que le resta que hazer en esta provincia por nezesitar de mas de cuatro meses por la distancia que ay de unas estancias a otras perjudicando en esto la real hazienda por el aujmento de salarios que se originaban en este tiempo; theniendo considerazion a la integridad y zelo en el servicio de su magestad y otras buenas partes que concurren en la persona del capitan don Manuel de Zevallos Neto y Estrada alguacil maior de esta ciudad y a la buena quenta que espera a de dar en este ministerio, le daba y dio comission la que puede y debe para que execute las dichas sentenzias yendo personalmente con el protector general a las dichas estancias para que se les asignen tierras a los dichos indios obligando a ello a los encomenderos por todo rigor de derecho como tambien a que otorguen instrumentto publico y autentico ante el escribano de cavildo para que [2r] en todo tiempo conste adbirtiendo que la dicha asignazion se a de hazer regulandose el numero de los indios por que en el de seis se le a de asignar media legua de tierras en cuadro, y de seis hasta diez tres cuartos de legua en cuadro, y en pasando de diez a 
diez y seis una legua en cuadro y siendo el numero que no llegue a seis bastara un cuarto de legua en cuadro, teniendo considerazion a que dichas tierras an de ser fructiferas y con agua sufiziente de calidad que sean utiles a los dichos indios y en partte comoda y que su reduzion y rancherias con la capilla que se a de fabricar a de ser en los terminos de dichas tierras y en la parte mas distante de las casas del encomendero; y asimismo le doy comision para que se executen las pagas que se huvieren dexado de hazer a los indios contenidos en dichas sentenzias y lo demas que nezesitare de execuzion y cumplimiento y expecialmente en la fabrica de la capilla que se a de hazer dentro del termino asignado en las sentencias y las que no tubieren tiempo fixo y expresado se entiende el de seis meses que señala por la ocupazion y travajo que a de tener el dicho alguazil maior y el dicho protector general cuatro pesos de a ocho reales corrientes a cada uno, en cada dia de los que legitimamentte se ocuparen en la hida y benida y estada que cobraran [repetido: que cobraran] de dichos encomenderos y siendo necesario obrar a por todo rigor [2v] de derecho para la cobranza de dichos salarios assi en los que le tocaren como en los del dicho protector. Y las justicias de esta ciudad daran a dicho capitan don Manuel de Zevallos dado el favor y ayuda que nezesitare concurriendo para efecto de lo referido en todo lo que les tocare. Dotor don Antonio Martinez Luxan de Vargas. Ante mi Lorenzo Pinto escrivano rezeptor.

[Al margen: Azettacion y juramento]

En la ciudad de Cordova en cuatro dias del mes de mayo de mill y seiscientos y nobenta y tres años parezio el capittan don Manuel de Zevallos Netto y Estrada alguazil maior propiettario de estta dicha ciudad a quien hize saber el nombramiento que contienne el auto de susso y haviendolo azepttado juro por Dios nuestro señor y una señal de cruz que hizo y zelebro segun forma de derecho de usar bien y fielmente el dicho cargo y lo firmo. Don Manuel de Zevallos Neto y Estrada. Ante mi Lorenzo Pinto escrivano rezeptor.

[3r] [Al margen: Auto]

En la ciudad de Cordova en diesinuebe diaz de el mes de setiempbre, de mill y seisientos y nobenta y tres años el capitan don Manuel de Zevallos alguasil mayor de esta ciudad, y juez de comision [tachado: de] nombrado por el señor doctor don Antonio Martines de Luxan y Vargas del consexo de su magestad oydor mas antiguo de la real audiensia de La Plata y juez vesitador general de esta provincia, para la execussion de las sentensias dadas por el dicho señor oydor y juez vesitador a los vezinos feudetarios de esta dicha ciudad. Dijo su merced que por quanto se halla [tachado: va] de proxcimo a salir a la jurisdiccion de esta dicha ciudad en compañia del capitan Juan Lopez de Fuentte Seca rexidor de esta ciudad y protetor general de los naturales. En virtud, de lo [entrelíneas: mandado] por dicho señor oydor y juez vesitador que a suspendido hasta el tiempo presente por la seca general que a havido imposibilitados, los bueyes y mulas. Para el servicio de dicho viaxe, mandava y mando se les notifique a los capitanes don Pedro de Olmos y Alonso Lujan se hallen en los paraxes de sus haziendas dentro de dose diaz, de la notificassion a dar cumplimiento a las sentensias dadas contra los susodichos por dicho señor oydor y juez vesitador, con apersevimiento que dicho termino pasado, no lo haviendo cumplido su merced reserva el proveer en dicha razon lo que conbenga y les parara todo entero perjuisio y lo firmo. Don Manuel de Zevallos Neto y Estrada. Ante mi Thomas de Salas escribano de su magestad.

[Al margen: Notificacion]

En Cordova en el dicho dia diesinuebe de setiembre de dicho año notifique el auto de suso a Alonsso Lujan de Medina en su persona que lo oyo de que doy fee, presentes los capitanes don Sevastian de Carranza alcalde de la santa hermandad y capitan Thomas de Subero Axpe, de ello doy fee. Thomas de Salas escribano de su magestad.

[Al margen: Otra notificacion] 
En la ciudad de Cordova en el dicho [3v] dia diesinuebe de setiembre de dicho año notifique el auto de suso, como en el se contiene al capitan don Pedro de Olmos y Aguilera en su persona que lo oyo doy fee. Thomas de Salas escribano de su magestad.

[Al margen: Señalamiento de tierras de el pueblo y redussion de los indios del capitan Miguel Moiano Cornejo]

En el paraje que llaman de Ministalolo el Viejo redusion y pueblo de los indios de la encomienda del capitan Miguel Moyano Cornejo siete leguas poco mas o minos de la çiudad de Cordova y en su jurisdiccion en veinte y sinco dias del mes de setiembre de mill y seisientos y nobenta y tres años. Yo el capitan don Manuel de Zevallos Neto Estrada alguasil mayor de la dicha ciudad, y juez nombrado por el señor doctor don Antonio Martinez Lujan de Vargas del consejo de su magestad y su oydor mas antiguo de la real audiensia de La Plata y vesitador general de esta provincia de el Tucuman por expesial comission del Rey nuestro señor para la execusion de las sentensias dadas por su señoria en la vesita que hizo de los indios de esta jurisdiccion, con asistencia del capitan Juan Lopez de Fuente Seca rexidor y protetor general de los naturales de dicha ciudad abiendo llegado ayer, veinte y quatro del corriente para dar cumplimiento a la sentensia dada por el dicho señor vesitador general en la vesita de dichos indios que pronunsio en sinco de el mes de abril de este pressente año contra el dicho encomendero a quien le notifique asignase tierras sufisientes y con el agua necesaria, para que en ellas tengan los dichos indios su redusion en la parte mas comoda y distante de su casa como se manda por dicha sentencia. $Y$ haviendo reconocido las que señalaria con dicho protetor e informadonos de la voluntad de los indios quienes [4r] dijeron les hera de su conbeniensia por haverlas cultivado en otras ocasiones y tenerlas pobladas con su familia un indio de esta encomienda llamado Mathias y tener sembrado al presente en ellas trigo que vimos siendo como lo son frutiferas y de buenos pastos, montes y cañadas para sus conveniensias con dos ojos de agua y posso grande que esta en el arroyo que vaja del sause, siendo la parte mas distante de las casas del encomendero en que les puede asignar las dichas tierras atendiendo a la mayor utilidad de los indios y atento a que los indios de dicho encomendero pasan del numero de seis y no llegan a diez en cumplimiento de lo mandado, por dicho señor vesitador general mande se les enterasen, midiesen y amojonasen, media legua en quadro a todas partes en cuya execusion medi un cordel de cañamo de sinquenta baras y haviendose reconosido los linderos que dividen las tierras que tocan al capitan Francisco Moyano Cornejo y Joseph Cornejo hermanos de dicho encomendero desde los que caen a la parte del norte, cojiendo de el sur, quarta al sudueste, se midieron sesenta cuerdas de a sinquenta varas que hasen tres mil que son las que pertenesen a la dicha media legua segun lo acostumbrado en esta jurisdiccion, y al final de ellos mande poner un mojon que cayo sobre una loma alta, quedando hasia la parte del norte del dicho mojon un arroyo que vaja del potrero que llaman del Sause, pertenesiente a dicho encomendero. $Y$ dentro de las tierras que pertenesen a dichos indios un manantial de agua que nase en dicho arroyo que cae enfrente de una loma alta. [4v] Y desde dicho mojon abiendo cojido el rumbo del este y media partida al [tachado: de] sueste, hasia la campaña se midieron otras sesenta cuerdas de a sinquenta baras y al final de ellas mande poner otro moxon de piedras que cayo en una cañada larga que corre de oriente a poniente. Y desde dicho moxon de suso referido cojiendo el rumbo del norte, quarta al nordeste, se midieron otras sesenta cuerdas de dichas sinquenta baras que alcansaron al pie de una loma alta y al medio de ella que corre de oriente a poniente y divide las tierras de la estansia de San Pablo que posee el dicho capitan Francisco Moyano Cornejo con lo qual quedaron medidas y amojonadas las dichas tierras de dicha media legua en quadro y en conformidad, de su asignasion, las declaro por tierras, pueblo y redusion de dichos indios devajo de los linderos y mojones de suso referidos. Para que las ayan y tengan por suias propias y usen de ellas en todo aquello que fuere de su utilidad y conbeniensia en cumplimiento de leies y hornanzas reales. $Y$ en su virtud le di a dichos indios y a su protetor en su nombre posesion de ellas en nombre de su magestad (Dios le guarde) 
cojiendole de la mano y paseandole por ellas en virtud de dicha comision se la di, real, aççtual, corporal [subrayado: yure domine belquasi], en forma y segun derecho. $Y$ el dicho protetor en señal de que la tomaria en nombre de sus partes arranco iervas, tiro piedras y mando a los pressentes se las dejasen libres a sus partes y de como asi la aprehendia y tomava como a las tres horas de la tarde en dia claro me pidio a mi dicho juez, se lo diese por testimonio, e yo se lo doi en quanto puedo y a lugar de derecho de haver sido y pasado como dicho es [5r] y en su conformidad mando a todas y qualesquier personas de qualquier estado, calidad y condision que sean no sean osados, a quitar ni mober los dichos mojones ni perturben ni inquieten a los dichos indios, de esta encomienda que al presente son y en adelante fueren de la posesion de dichas tierras so las penas dispuestas por derecho y de dosientos pesos aplicados camara de su magestad y de que se prosedera a las demas diligensias que convengan. $Y$ en conformidad de su asignasion mando al dicho capitan Miguel Moyano Cornejo que dentro de un mes otorgue instrumento publico y autentico ante el escrivano de cavildo de la dicha ciudad de Cordova de la asignasion de tierras que haze, a dichos indios devajo de los linderos de suso referidos para que en todo tiempo conste en cumplimiento de lo mandado por dicho señor vesitador general. Y en quanto a la capilla mandada haser, en dicha sentensia por no haver dado su cumplimiento en atension de no haver tenido pueblo asignado mando al dicho capitan Miguel Cornejo Moyano que dentro de seis meses primeros siguientes haga la dicha capilla en las dichas tierras que se les asigna para que los dichos indios oygan misa los dias de fiesta cuydando como es su obligasion de la doctrina cristiana y preseptos de nuestra santa fee catholica devajo de las penas y apersevimientos prevenidos y hordenados por dicho señor vesitador general, a quien e de dar quenta para que se sirva de proveer lo de mas que convenga. Declarando como declaro haver cumplido el dicho encomendero con la paga en que fue condenado por dicha sentensia diese a los indios e indias de su repartimiento por haver confesado los susodichos delante de mi, el dicho protetor general aberlos resevido [5v] y para que tenga en todo cumplido efecto mando a todos los dichos indios e indias muchachos y muchachas de esta encomienda luego se pueblen y asistan y mantengan en dichas tierras teniendolas por su redusion sin salir de ellas, mas que en los tiempos y cosas prevenidas por leies y hordenansas reales y mando al dicho encomendero les fomente a ello sin ponerles ningun estorbo ni sacarlos de dicha redusion cumpliendo en todo segun es obligado. Por cuyo cumplimiento les ley y notifique todo lo de suso referido al dicho encomendero y a los dichos indios, en sus personas que dijeron lo oyan y que estan prestos a cumplir con lo que se les manda cada uno por lo que [entrelíneas: les] toca y para que de ello lo firme yo dicho juez con el dicho encomendero y protetor por ante mi y testigos a falta de escrivano allandose presentes a todo lo referido Alonso de Ubeda, Agustin de Soria Medrano y Visente Jufre y lo firmaron conmigo los que supieron doy fee. Don Manuel de Zevallos Neto y Estrada. Juan Lopez de Fuente Seca. Miguel Moyano Cornejo. Agustin de Soria Medrano. Visente Jufre.

[Al margen: Señalamiento de tierras a los indios de la encomienda del capitan don Antonio de Vurgos]

En esta chacra de Guanusacate jurisdiccion de la ciudad de Cordova dies leguas poco mas o menos de ella en veinte y ocho diaz del mes de setiembre de mil y seisientos y nobenta y tres años yo el capitan don Manuel de Zevallos Neto y Estrada alguazil mayor de la dicha ciudad y juez nombrado por el señor doctor don Antonio Martines Lujan de Vargas del consejo de su magestad y su oydor mas antiguo de la real audiencia de La Plata y vesitador general de esta provincia de Tucuman por particular comission del Rey nuestro señor para la execusion de las sentensias dadas por su señoria en la vezita que hizo de los indios de [6r] [repetido: de] esta jurisdiccion con asistencia del capitan Juan Lopez de Fuente Seca rexidor y protetor general de dicha ciudad de Cordova, haviendo llegado a esta dicha chacra y hazienda del capitan don Antonio de Burgos Zelis Quiroga vesino feudattario, para dar cumplimiento a la sentensia dada por dicho señor vesitador general en dicha ciudad de Cordova en nuebe del mes de abril de este presente año de 
nobenta y tres contra el dicho encomendero, a quien le hize notoria la comision a mi dada por dicho señor vesitador general y en su cumplimiento le notifique asignase tierras a los indios de nasion calchaqui que tiene en su repartimiento para que en ellas tengan su redusion en la parte mas comoda y distante de su cassa con el agua nesesaria para que en ellas puedan residir y tener sus conbeniensias. $Y$ haviendose reconosido por mi dicho juez y protetor con los indios de esta encomienda las tierras que les señalaria a dichos indios en atension a ser frutiferas y de pan llevar asequiadas parte de ellas y serles de conbeniensia a dichos indios sin envargo de no poder estar poblados de las casas del encomendero mas distansia que de sinco quadras por ser chacras y que puedan gosar del agua de la asequia principal que tiene dicha hazienda, se le admitio la dicha asignacion de tierras. Y en su conformidad, mande en atension a que los dichos indios de este repartimiento son tres se les haga el entero de un quarto de legua en quadro a todas partes como lo manda dicho señor vesitador general en cuya execusion medi un cordel de cañamo de sinquenta baras y abiendose reconosido, ayer veinte y siete del corriente los linderos que divide la chacra y tierras que son de los herederos de doña Zavina de Bustamante y Albornos, difunta, corriendo de sur a norte, se midieron treinta querdas de dichas [6v] sinquenta baras que terminaron en el rio que llaman de Jhesus Maria que corre de oriente a poniente que hasen un mill y quinientas varas que son las que pertenesen a dicho quarto de legua segun se acostumbra en esta jurisdicion. $Y$ aviendo buelto de donde se empeso a medir el dicho quarto de legua, de donde se puso un mojon de un palo grueso de algarrobo cojiendo el rumbo del este y media partida al nordeste se midieron otras treinta cuerdas de dichas sinquenta baras, quedando por este rumbo dentro de las tierras de dichos indios una guerta de arboles frutales, antigua, y al final de las dichas treinta cuerdas se puso otro mojon de un palo de algarrobo y del cojiendo el rumbo del sur a la parte del norte se midieron otras treinta cuerdas de dichas sinquenta varas que terminaron en el dicho rio de Jhesus Maria junto a un tala grande, adonde y en su tronco mande haser una cruz para que sirva de lindero y señalamiento de tierras de esta redusion con lo qual quedaron medidas y amojonadas las dichas tierras de quarto de legua en quadro y en conformidad de su asignasion las declaro por tierras y redusion de dichos indios devajo de los linderos y mojones que van expresados para que las ayan y tengan por suyas propias y usen de ellas los dichos indios de esta redussion que al presente son y en adelante fueren en todo aquello que les fuere de su utilidad y conbeniensia segun leies y hordenansas reales con obligasion que hase el dicho encomendero por si y en nombre de los demas sus herederos y subsesores que le subsidieren en el derecho de esta dicha chacra de Guano[7r]sacate de dar el agua que ubieren menester perpetuamente para su conservasion a los dichos indios, de esta redusion, de la asequia que tiene corriente segun le pertenese a las tierras de esta chacra con las de dicha redusion. Y en conformidad de dicha asignasion y amojonamiento les di a los dichos indios y a su protetor en su nombre, posesion de dichas tierras devajo de los linderos de suso referidos en nombre de su magestad (Dios le guarde) cojiendole de la mano y paseandole por ellas se la di real actual corporal yuri domini velquasi en forma de derecho. $Y$ el dicho protetor en señal de que la tomaria arranco iervas y mando a los que presente estavan se las dejasen libres a sus partes y de como asi la haprehendia y tomaba como a las onse de la mañana me pidio a mi dicho juez se lo diese por testimonio e yo se lo doy en quanto puedo y a lugar de derecho de haver sido y pasado como dicho es. Y en su conformidad, mando a todas y qualesquier personas de qualquier estado calidad y condision que sean, no sean osados a quitar ni mober los dichos mojonez ni perturben ni inquieten a los indios de esta redussion que al presente son y adelante fueren, de la posesion que haprehenden de las dichas tierras y se las dejen sembrar y cultivar y usar de ellas libremente en todo aquello que les fuere de su conbeniensia so las penas dispuestas por derecho y de dosientos pesos, mas, aplicados camara de su magestad y de que se prosedera a las demas diligensias que convengan. $\mathrm{Y}$ en conformidad de su asignasion, mando al dicho capitan don Antonio de Burgos, que dentro de un mes, otorgue instrumento publico ante el escrivano de cavildo [7v] de dicha ciudad de Cordova de la asignasion que haze de estas tierras a dichos indios de su repartimiento 
para su perpetuidad, devajo de los linderos y calidades expresadas en cumplimiento de lo mandado por dicho señor vesitador general. Y en quanto a la capilla mandada haser por dicha sentencia que no a dado cumplimiento en atension de no haver tenido tierras señaladas a dichos sus encomendados, mando al dicho capitan don Antonio de Burgos que dentro de seis meses primeros siguientes haga la dicha capilla en las dichas tierras que se les asignan, para que dichos indios oygan misa los dias de fiesta y se les enseñe la doctrina cristhiana a las horas y tiempos prevenidos por reales hordenansas, devajo de las penas y apersevimientos hordenados y prevenidos por dicho señor vesitador general a quien e de dar quenta para que se sirva de probeer lo demas que conbenga. Declarando como declaro haver cumplido el dicho encomendero con las pagas mandadas haser a dichos indios por dicha sentensia en atension a aber declarado asi en mi presensia, por haverlas resevido en la ciudad, en presensia de dicho protetor general, quien lo confeso asi. Y para que en todo ayga cumplido efecto mando a todos los dichos indios e indias muchachos y muchachas de esta redusion luego se pueblen y asistan y mantengan en dichas tierras que asi se le asigna teniendolas por su redusion, sin salir de ellas mas que en los tiempos y casos prevenidos por leies y hordenansas y ayudando al dicho su encomendero a la fabrica de dicha capilla en aquello que son obligados. Y mando al dicho encomendero les fomente a ello sin ponerles ningun estorbo ni sacarlos de dicha su redusion cumpliendo con todo aquello, que es, obligado para su mejor [entrelíneas: anparo] [8r] y conservasion. Para cuyo cumplimiento les ley y notifique todo lo de suso referido a los dichos encomendero y a dichos indios, en sus personas que dijeron lo oyan y que estan prestos a cumplir con lo que se les manda cada uno por lo que les toca y para que de ello conste lo firme yo dicho juez con dicho protetor y testigos que se hallaron presentes a falta de escrivano y no firmo dicho encomendero por estar siego y desir no podia; hallandose presentes a todo lo referido el capitan don Jil de Burgos, don Juan de Salinas, don Diego de Burgos y Juan Clemente de Gusman, de ello doi fee. Don Manuel de Zevallos Neto y Estrada. Juan Lopez de Fuente Seca. A ruego del encomendero y por testigo don Gil Seliz de Burgos. Testigo don Diego Zelis de Burgos y Quiroga. Testigo don Juan de Salinas y Cabrera. Testigo Juan Clemente de Gusman.

[Al margen: Autto]

En esta estansia del Totoral llamada San Antonio de Buenavista jurisdiccion de la ciudad de Cordova diesiseis leguas de ella en treinta dias del mes de setiempbre de mill y seisientos y nobenta y tres años. Yo el capitan don Manuel de Zevallos alguazil mayor y juez nombrado por el señor doctor don Antonio Martinez Lujan de Vargas del consejo de su magestad y su oydor mas antiguo de la real audiencia de La Plata y vesitador general de esta provinsia del Tucuman por expesial comision de el Rey nuestro señor para la execusion de las sentensias dadas por dicho señor juez vezitador a los vezinos encomenderos de esta jurisdiccion. Digo que haviendo llegado a esta dicha estansia de San Antonio de Buenavista y hallado en ella al capitan don Juan Xuares de Cabrera uno de dichos encomenderos le lei e hize notoria la comision a mi dada por dicho señor vezitador general [8v] y en su cumplimiento mando al susodicho que de entro de segundo dia les asigne a los indios de su repartimiento tierras vastantes para que juntos esten en redusion y que conparescan ante mi todos los indios de esta encomienda para que reconosidos por mi y el protetor de los naturales, con dichos indios las que asignare se provea lo demas que conbenga. $Y$ para que se execute y sean pagados los dichos indios de los diez pesos mandados dar a cada uno por dicha sentensia mando asimesmo a don Domingo Cocayan curaca de dichos indios los traiga a mi presensia y a la de su protetor para la aberiguasion de si estan pagados de dicha condenasion con apersevimiento que dicho termino pasado no le haviendo cumplido reservo proveer lo demas que conbenga y asi se les notifique por mi dicho juez asi lo provey y firme por ante mi y testigos a falta de escrivano. Don Manuel de Zevallos Neto y Estrada. Testigo Juan Lopez de Fuenteseca. Don Pablo de Algañaras y Murguia.

[Al margen: Notificacion] 
Luego encontinenti yo dicho juez ley y notifique el auto de esta otra parte al capitan don Juan Xuares de Cabrera y al dicho curaca don Domingo Cocayan en sus personas que lo oyeron y en su cumplimiento el dicho encomendero dixo que señala las tierras del rio hondo que tocan a la merced de Pisco Guasi, que son suias propias y el dicho curaca dijo cunpliria con lo que se le manda trayendo ante mi los [entrelíneas: indios] que al presente se hallan de esta encomienda y en conformidad de su asignasion manda se reconoscan las dichas tierras por mi y con asistensia del protetor y dichos indios [9r] con vista de que reservo proveer lo que conbenga y para que de ello conste, lo firme con la parte y testigos. Don Manuel de Zevallos Neto y Estrada. Don Juan Suarez de Cabrera. Juan Lopez de Fuente Seca. Don Pablo de Algañaras y Murguia.

[Al margen: Señalamiento de tierras a los indios de la encomienda del capitan don Juan Xuares de Cabrera]

En este paraje de Vaca Corral jurisdiccion de la ciudad de Cordova veinte y dos leguas de ella, poco mas o menos en dos dias del mes de ottubre de mill y seisientos y nobenta y tres años. Yo el capitan don Manuel de Zevallos alguazil mayor de dicha ciudad y juez nombrado por el señor doctor don Antonio Martinez Luxan de Vargas, del consejo de su magestad su oydor mas antiguo de la real audiensia de La Plata y vesitador general de esta provincia de Tucuman, por expesial comision del Rey nuestro señor en cunplimiento de la asignasion de este dicho paraxe que del hizo el capitan don Juan Xuares de Cabrera para redusion de los indios de su encomienda, en cunplimiento del auto por mi proveydo en treinta de setiembre pasado y de la sentensia que dicho señor vesitador general se sirvio de dar, en la vesita que hizo de esta encomienda en dicha ciudad de Cordova en ocho del mes de abril de este presente año, de mill y seisientos y nobenta y tres aviendo llegado a este dicho paraxe con asistensia del capitan Juan Lopez de Fuente Seca rexidor y protetor general de los naturales y de don Domingo Cocayan curaca de dichos indios y de Lucas, Juan y Geronimo indios de esta encomienda y con tres indias mas de dicha encomienda que mande pareser ante mi, para que en su presensia se reconosiesen dichas tierras y haviendolo hecho con su asistensia y la de dicho protetor, haviendolas hallado con agua bastante y tierra frutiferas de pan llevar, con pastos y montes para conbeniensia de dichos indios las ube por asignadas y en su conformidad y que los indios de esta encomienda son siete con [9v] tres que estan ausentes mando se les entere media legua en quadro a todas partes en cumplimiento de lo mandado por dicho señor vesitador general y poniendolo por diligensia mande medir un cordel de cañamo de sinquenta baras y haviendose reconosido los linderos de las tierras de Chipitin que poseen los herederos de Lusia Rodriguez cojiendo desde junto a un camino que sale de las casas viejas de Chipitin, y va al pueblo de Guazascate adonde mande poner un moxon de algarrobo y cojiendo el rumbo de oeste, al este, se midieron sesenta cuerdas de a sinquenta baras que hasen tres mill varas que son las que pertenesen a la dicha media legua y al final de ellas mande poner otro mojon de un algarrobo en tronco que cayo junto al camino antiguo de carretas que ba a la ciudad de Santiago del Estero. Y de dicho moxon cojiendo el rumbo del sur asia la partte del norte, se midieron otras sesentta cuerdas de sinquenta varas y al final de ellas mande poner otro moxon que cayo veinte y ocho cuerdas pasado un rio seco que atraviesa dichas tierras. Y cojiendo desde dicho mojon del este al sueste se midieron otras sesenta cuerdas de a sinquenta baras que hasen otra media legua que terminaron en una cañada junto a una loma vaja adonde mande poner otro moxon de un palo de algarrobo y haze frente de norte a sur, con el primer lindero de donde se empeso a medir estas dichas [10r] tierras quedando dentro de estos linderos dos oxos de agua que nasen en un arroyo que baja del Potrero de Piscoguasi, que posee dicho encomendero y en uno de dichos ojos de agua y serca de los linderos de la parte del oeste, hallamos poblado por horden del dicho encomendero a Miguel de Torres y en conformidad de la dicha asignasion, le mande que dentro de segundo dia las desocupe y deje libres y desembarasadas a dichos indios pena de lansamiento en forma. Con lo qual quedaron medidas y amoxonadas las dichas tierras de media legua en quadro y en conformidad de su asignasion las declaro por pueblo y redusion de 
dichos indios devajo de los linderos de suso referidos para que las ayan y tengan por suyas propias y usen de ellas en todo aquello que fuere de su utilidad, en cumplimiento de leyes y hordenansas reales. Y en su virtud, en nombre de su magestad (que Dios guarde) le di posesion de dicho paraxe de Vaca Corral al dicho curaca don Domingo Cocayan por si y en nombre de los demas indios de esta encomienda que al presente son y en adelante fueren cojiendose de la mano y paseandole por ella se la di real acctual corporal iuri domini velquasi en forma y segun derecho y en señal de que la tomaria arranco iervas, tiro piedras e hizo otros aççtos de posesion y mando a los presentes se las dejasen libres y desembarasadas y de como asi la aprehendia como a las tres de la tarde en dia claro y sin contradision de persona alguna me [10v] pidio a mi dicho juez, se lo diese por testimonio y yo se lo doy en quanto puedo y a lugar de derecho de haber sido y pasado como dicho es, y en su conformidad mando a todas y qualesquier personas de qualquier estado, calidad y condision que sean no sean osados a quitar ni mober los dichos moxones ni inquieten, ni pertuben a dichos indios de esta encomienda que al presente son y en adelante fueren de la posesion de estas dichas tierras so las penas dispuestas por derecho y de dosientos pesos aplicados camara de su magestad, y de que proseden a las de mas diligensias que conbengan. $Y$ en conformidad de su asignasion, mando al dicho capitan don Juan Xuares de Cabrera que dentro de veinte dias otorgue instrumento publico y autentico, ante el escrivano de cavildo de la dicha ciudad de Cordova devaxo de los linderos de suso referidos, para su perpetuidad, en cumplimiento de lo mandado por dicho señor vesitador general. Y en quanto a la capilla mandada haser en dicha sentensia por no haver dado su cumplimiento en atension de no haver tenido pueblo asignado, mando al dicho capitan don Juan Xuarez de Cabrera que dentro de seis meses primeros siguientes haga dicha capilla en estas dichas tierras que se les asignan para que los dichos indios oygan misa los dias de fiesta cuidando como es de su obligasion de la enseñanza de la doctrina cristhiana devajo de las penas y apersevimientos prevenidos y hordenados por dicho señor vezitador general a quien reservo dar quenta para que se sirva de proveer lo demas que convenga. $Y$ en [11r] cuanto a la paga de dies pesos a cada indio de esta encomienda mandada haser por dicho señor vesitador general mande pareser antte mi y dicho protetor al dicho curaca y a los dichos indios Lucas, Juan y Geronimo, a quienes pregunte si su encomendero les tenia pagada la dicha cantidad y por haver dicho que no la tenian resevida, mande al dicho encomendero que luego y sin dilasion alguna de y pague a cada uno los dichos diez pesos lo qual executo luego en mi presensia y la de dicho protetor general en xeneros de pañete, lienzo y vayeta a presios corrientes, de que se dieron por contentos y entregados. $Y$ en quanto a la paga del indio Francisco y su hijo Mathias y Fhelipe por estar ausentes, se les dexa su derecho a salvo para en viniendo haserles pagar lo mandado por dicho señor oydor y vesitador general y mando al dicho curaca asi se lo haga saber. Y para que todo tenga cumplido efecto, mando al dicho curaca indios indias muchachos y muchachas de esta encomienda luego se pueblen asistan y mantengan en dichas tierras teniendolas por su redusion sin salir de ellas mas que en los tiempos y cosas prebenidas por leies y hordenansas reales y mando al dicho encomendero los fomente a ello, sin ponerles ningun estorbo, ni inpedimento ni sacarlos de su redusion cumpliendo en todo con lo que es obligado. Para cuyo cumplimiento les ley y nottifique todo lo de suso referido al dicho encomendero, curaca e indios en sus personas que dijeron lo oyan y que estan prestos a cumplir con lo que se les manda cada uno por lo que les [11v] toca y para que de ello conste, lo firme yo dicho juez con el dicho encomendero y protetor por ante mi y testigos a falta de escrivano siendolo presentes a todo lo referido, Joseph de Quintero Miguel de Torres, Diego Quintero y Simon de Andrada que lo firmaron los que supieron y de ello doy fee. Don Manuel de Zevallos Neto y Estrada. Juan Lopez de Fuente Seca. Don Juan Suarez de Cabrera. Joseph Quintero. Miguel de Torres.

[Al margen: Reconosimiento y fe de la capilla del pueblo de San Antonio de Nonsacate encomienda del comisario don Bartolome de Olmos] 
En el pueblo de San Antonio de Nonsacate encomienda del comisario don Bartolome de Olmos y Aguilera juridision de la ciudad de Cordova veinte y ocho leguas de ella poco mas o menos, en nuebe diaz del mes de otubre de mill y seisientos y nobenta y tres años. Yo el capitan don Manuel de Zevallos Neto y Estrada alguazil mayor de la dicha ciudad, y juez nombrado por el señor doctor don Antonio Martinez Lujan de Vargas del consejo de su magestad y su oydor mas antiguo de la real audiensia de La Plata vesitador general de esta provinsia de Tucuman por expesial comision del Rey nuestro señor para la execusion de las sentensias dadas por dicho señor vezitador general en la vezita de indios que hizo de los de esta juridision y por lo que toca a la dada por su señoria en este dicho pueblo su fecha en catorse de mayo de este presente año vine a este dicho pueblo y con asistensia del capitan Juan Lopez de Fuente Seca Rexidor y protetor general de los naturales y de los testigos de suso escritos a falta de escrivano para el recononosimiento de la capilla man[12r][entrelíneas: dada haser] en dicha sentensia y por vista de ojos que hize, sertifico en quanto puedo y a lugar de derecho que halle levantada y hecha una capilla echa de adoves, y tapias de tierra cubiertta y techada sobre dos tirantes de quebracho y sobre los tirantes y en medio dos pilares de algarrobo pequeños que tienen dos cumbreras y varason de quebracho, encañada y cubierta de paja y en la testera de dicha capilla un altar hecho de adoves, con su tarima y marco de madera sin adorno para poder desir missa y desde el primer tirante, atajado con piedra y varro y marco para poder poner puertas y haviendola reconosido en este estado me dijo don Baltasar de Melo curaca de este dicho pueblo y otros indios de el, la avian ataxado por agora, y para que se les dixese missa porque la querian alargar otro tirante mas, con su corredor porque tenian ya prevenido lo nesesario y adoves hechos que estos, sertifico asi mismo bide hechos cantidad de ellos, y asi mismo fuera de dicha capilla y enfrente una santa cruz grande de madera de algarrobo nueba que la dicha capilla y demas sertificado dijeron el dicho curaca e indios la avian hecho y puesto en la forma suso dicha por si, y sin ayuda de su encomendero ni de otro español, ni persona alguna y para que de ello conste a dicho señor oydor $[12 v]$ vezitador general asi lo sertifico y pongo por diligencia y lo firme con dicho protetor general y testigos presentes a todo lo referido Ignaçio de Cardenas, don Joseph de Olmos y Aguilera y don Bartolome de Olmos y Aguilera doy fee. Don Manuel de Zevallos y Estrada. Juan Lopez de Fuente Seca. Testigo don Joseph de Olmos Pimentel. Testigo Ignasio de Cardenas. Testigo Don Bartolome de Olmos y Aguilera.

[Pagas de los indios que sirvieron a don Pedro de Olmos]

Y luego encontinenti el dicho dia, mes y año arriva dichos yo el dicho alguazil mayor y juez con asistensia del dicho protetor mande pareser ante mi, a quatro indios de dicha encomienda, que sirvieron al capitan don Pedro de Olmos y Aguilera llamados Juan, Rodrigo, Geronimo y Diego; quienes alcansaron al susodicho en siento y treinta y quatro pesos como consta de la obligasion que hizo de pagarselos dentro de un mes ante el dicho señor oydor vezitador, al indio Juan quarenta pesos, a Rodrigo cinquenta, a Geronimo veinte y quatro, a Diego veinte pesos, cuyas cantidades cada uno de dichos indios confesaron, ante mi dicho juez y su protetor y testigos, estar pagados cada uno de la dicha cantidad, de mano del dicho capitan don Pedro de Olmos y Aguilera a toda su satisfasion. [13r] Y por lo que toca a la satisfasion de los siento y nobenta pesos que a de pagar, el capitan don Joseph de Olmos y Aguilera a cuatro indios de esta encomienda llamados Domingo, Sevastian, Pedro y Francisco, atento a que el susodicho se halla en su estansia de Massa dos leguas de esta encomienda por confesar los dichos tener resevido del susodicho parte de su cantidad, mando conparescan ante mi y se liquide la quenta con asistensia de su protetor y se les pague el alcanse, que le hizieren. Y para que conste lo firme por ante mi y testigos a falta de escrivano. Don Manuel de Zevallos Neto y Estrada. Juan Lopez de Fuente Seca. Testigo. Ignasio de Cardenas. Testigo. Don Joseph de Olmos y Pementel. Testigo. Don Bartolome de Olmos y Aguilera. 
[Al margen: Pagas echas por don Joseph de Olmos]

En esta estansia de Masa en diez dias de el mes de otubre de mill y seisientos y nobenta y tres años. Yo el capitan don Manuel de Zevallos alguazil mayor y juez nombrado por dicho señor oydor y vezitador general en cumplimiento del decreto de suso y con asistensia del capitan Juan Lopez de Fuente Seca rexidor y protetor [13v] general de los naturales vine a esta dicha estancia para la liquidasion y ajuste del jornal de los indios; que an servido al capitan don Joseph de Olmos segun la obligasion que hizo en catorse de mayo de este presente año ante dicho señor oydor y vesitador general y haviendose hecho con asistensia de los dichos indios y lo que rezulto deviendo de resto que no les avia acavado de pagar fueron ochenta y quatro pesos y sinco reales en la forma siguiente. A Domingo catorse pesos y tres reales al cumplimiento de los sesenta que le devia pagar. A Sevastian veinte y quatro pesos de resto de los sinquentta pesos que le devia pagar. A Pedro beinte y tres pesos y quatro reales de resto de los quarenta pesos. Y a Francisco veinte y dos pesos y seis reales de resto de quarenta pesos. Los quales le mande yo dicho juez al dicho capitan don Joseph de Olmos y Aguilera que luego y sin dilasion alguna los diese y pagase, a los dichos indios. En cuyo cumplimiento y en mi presensia y de dicho protetor y testigos les pago a los dichos quatro indios los dichos ochenta y quatro pesos y sinco reales, segun lo que a cada uno tocaba en ropa de [14r] la tierra, pañete, bayeta y lienzo a presios corrientes a nuestra satisfasion y de dichos indios de que se dieron por entregados, en cuya conformidad, se le da por libre de los siento y nobenta pesos de su obligasion por estar satisfecha y pagada en todo y para que conste lo pongo por diligensia y lo firme por ante mi y testigos, que fueron presentes don Joseph de Olmos Pimentel y Ignasio de Cardenas con dicho protetor y la parte. Don Manuel de Zevallos Neto y Estrada. Juan Lopez de Fuente Seca. Don Joseph de Olmos y Aguilera. Testigo. Ignasio de Cardenas. Testigo. Don Joseph de Olmos Pimentel.

[Al margen: Redussion de los indios del maestre de campo Juan de Perochena]

En el pueblo y paraje de Quilpo de los indios de la encomienda de el maestre de campo Juan de Perochena juridision de la ciudad de Cordova veinte y dos leguas poco mas o menos de ella en diesiseis dias del mes de otubre de mill y seisientos y nobenta y tres años yo el capitan don Manuel de Zevallos Neto y Estrada alguazil mayor y juez nombrado por el señor doctor don Antonio Martinez Luxan de Vargas del consejo de su magestad y su oydor mas antiguo de la real audiensia de la ciudad de La Plata y visitador general de esta provincia de Tucuman, por expesial comi[14v]sion del Rey nuestro señor para la execusion de las sentensias dadas a los vezinos feudatarios de esta dicha juridision y por lo que toca a la dada al dicho maestre de campo Juan de Perochena su fecha en el Totoral, en nuebe dias del mes de mayo de este presente año vine a este dicho pueblo de Quilpo de los indios de dicha encomienda con asistencia del capitan Juan Lopez de Fuente Seca rejidor y protetor general de los naturales y de los testigos de suso escriptos a falta de escrivano. Sertifico en quanto puedo y a lugar de derecho que reconosido dicho pueblo y sus tierras halle ser buenas, comodas, y bastantes para dichos indios con el agua muy sufisiente de un rio grande, que pasa y corre por medio de sus tierras teniendo en el, tierras bastantes frutiferas, de pan llevar; estando asequiadas segun reconosi, y en parte con un jiron de cal y canto antiguo la qual se saco de dicho rio segun parese y al presente no corre, por estar siega y haverse desamparado por dichos indios segun me informaron Diego y Cristoval de esta encomienda; a quienes sertifico halle en dicho pueblo y tierras con dos ranchos que estaban haziendo para vivir y resedir en dicho pueblo con sus mugueres e ixos para cuyo efecto me dixeron los avian despachado, el dicho su encomendero en cumplimiento de lo man[15r]dado por el dicho señor oydor y vezitador general y para que se reduxesen a este dicho pueblo los demas indios que se hallan ausentes. Y por lo que toca a la capilla que debe tener, sertifico asi mismo esta cayda la antigua que fue de este dicho pueblo no hallando de ella mas que unas tapiaz viejas caydas, en cuya virtud, mando se le notifique al dicho encomendero haga capilla en este dicho 
pueblo de Quilpo cumpliendo en todo con su obligasion segun es obligado por dicha sentensia y fecha la dicha notificasion, se de quenta a dicho señor oydor y vezitador general para que le conste y se sirva de mandar lo demas que conbenga y para que de ello conste lo firme con dicho protetor y testigos que lo fueron presentes el capitan Pedro Ladron de Guebara y el ayudante Antonio Lopez de Figueredo. Don Manuel de Zevallos Neto y Estrada. Juan Lopez de Fuente Seca. Pedro Ladron de Guebara. Antonio Lopez de Figueredo.

[Al margen: Noticia] [Tachado: Notificacion]

En la ciudad de Cordova en veinte y siete dias del mes de otubre de mil y seisientos y nobenta y tres años yo el presente escrivano de su magestad hize saber el auto de esta otra parte al señor maese de campo Juan de Perochena theniente general de esta provinsia y vezino encomendero de esta jurisdiccion [15v] en su persona que lo oyo y dixo que estando su merced a ir a dar cumplimiento con lo que es obligado y poner en execusion el haser la dicha capilla por pedir su asistensia le fue remitida horden del señor don Martin de Xauregui governador y capitan general de esta provinsia para que la executase, por lo que inportaba su execusion al servisio de su magestad en que asta el dia de oy se allado entendiendo y porque es nesesario cortar las maderas en tiempo oportuno para su durasion, se halla su merced entendiendo en lo referido, que executara como es de su obligasion, quanto antes, y fecha daran notisia a su merced de dicho señor juez para que le conste y cumpla con lo que se le manda por el señor oydor y vezitador general y a su merced se le de por libre de dicha obligasion y esto dio por su respuesta y lo firmo de que doy fee. Juan de Perochena. Ante mi Thomas de Salas escrivano de su magestad.

[Al margen: Reconosimiento de capilla en el pueblo de Salsacate encomienda de don Fernando Salguero]

En el pueblo y paraxe de Salsacate de los indios de la encomienda del maese de campo don Fernando Salguero jurisdiccion de la ciudad de Cordova veinte leguas poco mas o menos de ella en diesinuebe diaz del mes de otubre de mill y seisientos nobenta y tres años yo el capitan don Manuel de Zevallos Neto y Estrada alguazil mayor y juez nombrado por el se[16r]ñor doctor don Antonio Martinez Luxan de Vargas del consejo de su magestad y su oydor mas antiguo de la real audiensia de La Plata vezitador general de esta provincia de Tucuman por expesial comision de su magestad para la execusion de las sentensias dadas a los vezinos feudetarios de esta dicha juridision y por lo que toca a la dada contra el dicho maestre de campo don Fernando Salguero vine a este dicho pueblo de Salsacate de los indios de dicha encomienda y sertifico en quanto puedo y a lugar de derecho que haviendo reconosido dicho pueblo, con asistensia de los testigos de suso escritos y de don Fhelipe Malla Cantaonco que haze ofisio de quraca por menor el lixitimo $\mathrm{y}$ otros indios de este dicho pueblo, no se halla dentro de el hecha la capilla que devia haver acavado, el dicho encomendero, cuyo termino es cumplido por el que se le asigno por dicha sentensia y le esta notificada su fecha en catorse dias del mes de abril de este presente año y para que tenga en todo cumplido efecto mando se le notifique al dicho maestre de campo cunpla con lo que es obligado declarando (como le declaro) por el todo, incurso, en las penas contenidas en la hordenza veinte por hagora (y hasta que dicho señor oydor vizitador general) con vista de lo obrado [16v] provea y mande, lo que mas fuere en justisia para cuyo efecto, se le remita testimonio y asi, lo provey mande y firme por ante mi y testigos a falta de escrivano siendolo presentes el sargento mayor Francisco de Ledesma el alferez Jasinto de Vilches, Ignaçio de Ledesma y Antonio de Arguello que lo firmaron los que supieron. Don Manuel de Zevallos Neto de Estrada. Francisco de Ledesma. Ignasio de Ledesma Zevallos. Antonio Arguello.

[Al margen: Autto]

En la ciudad de Cordova provinsia del Tucuman, en veinte y siete dias del mes de otubre de mill y seisientos y nobenta y tres años el capitan don Manuel de Zevallos Neto y Estrada alguazil mayor 
de esta ciudad, y juez de comision, como de suso va expresado por el señor doctor don Antonio Martinez Luxan de Vargas del consejo de su magestad y su oydor mas antiguo de la real audiensia de La Plata y vesitador general en esta provincia por expesial comision de su magestad, dixo que en atension a allarse el maestre de campo don Fernando Salguero de Cabrera vezino encomendero en esta ciudad el presente escrivano le notifique el auto por su merced proveydo en diesinuebe diaz del mes de otubre, para que [17r] le conste lo obrado en razon de la comision de suso mensionada y juntamente se le notifique, de y pague luego incontinenti veinte y quatro pesos de costas que por razon de salarios le son señalados a su merced, por la diligensia de tres dias de ida a su pueblo de Salsacate y tres dias de buelta que corresponde a los dichos veinte y quatro pesos a quatro pesos por dia y la dicha notificasion la ponga por fee asi lo proveyo mando y firmo don Manuel de Zevallos Neto y Estrada. Ante mi. Don Luis Isquierdo de Guadalupe escrivano publico y de cabildo.

[Al margen: Notificacion]

En la ciudad de Cordova en treinta dias del mes de otubre del dicho año yo el presente escribano fize nottorio, lei, notifique el auto de suso uno y otro, segun se me manda y se contiene en el ultimo al maestre de campo don Fernando Salguero que dixo lo oya y entendia y en su virtud exsivio y me entrego los veinte y quatro pesos, de costas que se le mandan dar luego en mi mano propia y de la mia propia pasaron incontinenti a mano del señor alguazil mayor y juez de comision capitan don Manuel de Zevallos y de dicha data y entriega y de todo lo demas doy fee. $[17 v]$ Don Luis Isquierdo de Guadalupe, escrivano publico y de cavildo.

[Al margen: Diligensia sobre la capilla de el pueblo de Ongamira encomienda del sargento mayor Francisco de Ledesma]

En la estansia y paraxe del rio Hondo valle de Salsacate, juridision de la ciudad de Cordova diesisiete leguas poco mas o menos de ella en veinte dias del mes de otubre de mill y seisientos y nobenta y tres años. Yo el capitan don Manuel de Zevallos Neto de Estrada alguazil mayor y juez nombrado por el señor doctor don Antonio Martinez Luxan de Vargas del consexo de su magestad, y su oydor mas antiguo de la real audiensia de la ciudad de La Plata vezitador general de esta provinsia de Tucuman por expesial comision de su magestad para la execusion de las sentensias dadas contra los vezinos encomenderos de esta dicha juridision, haviendo llegado a este dicho paraxe y hallado en el y su estansia al sargento mayor Francisco de Ledesma uno de dichos vezinos y ser comprehendido en la fabrica y capilla que deve haver fecho en el pueblo de Ongamira de sus encomendados, cuyo plazo que se le asigno por dicho señor oydor y vezitador general como consta por dicha sentensia y notificasion que se le hizo es cumplido y para que conste [18r] su cumplimiento y por em [sic] presensia de los testigos de iuso escriptos a falta de escrivano le lei, notifique e hize notoria la comision a mi dada por dicho señor oydor y vezitador general y zite en forma al susodicho e hize saver como en prosecusion de lo que se me hordena y manda por dicha comision paso luego encontinenti al dicho su pueblo de Ongamira al reconosimiento que devo hazer de dicha capilla para que y lo mas que se pueda ofrecer en dicho pueblo le requeri su asistencia; todo lo qual oydo y entendido por el dicho sargento mayor Francisco de Ledesma encomendero de dicho pueblo dijo. Que hablando con el respeto y venerasion que debe no a dado el cunplimiento a que es obligado segun lo mandado por dicha sentensia en la fabrica de la capilla por causa de los pocos indios de su encomienda pues ademas de ser solos dos se halla el uno ausente sin tener notisia donde y el otro enfermo a mas tiempo de sinco meses, causa porque no la a fecho y en su cumplimiento la hara segun que es obligado luego que paresca el ausente y mejore el enfermo y en quanto a la liquidasion de quentas que se [18v] le manda haga con dichos indios, no lo a hecho por las causas referidas y cuidado de dichos indios por el alcanze que conosen les haze lo qual pondra en execusion y pagara el que se le hizien [sic] y por lo que toca a los quatro pesos en que fue condenado los tiene pagados y satisfechos a Pablo 
que esta enfermo a quien yo dicho juez entre a ver a su rancho y preguntado, dijo ser asi, y haverlos rezevido en lienzo a presios corrientes y porque dicho encomendero nada dio el cumplimiento que deve en lo que toca a haver fabricado la dicha capilla en dicho pueblo de Ongamira de sus encomendados y para que tenga en todo cunplido efecto mando cumpla con lo que es obligado en horden a hazer la dicha capilla, luego sin envargo de las causas que por motibo refiere y en pena de no haverlo cunplido y hasta que la acabe lo declaro incurso en la hordenanza veinte por lo que toca a que no cobre ni persiva los tributos que conforme la hordenanza devia persevir de sus encomendados y por aora hasta que dicho señor oydor y vezitador general con vista de lo obrado a quien e de dar [19r] quenta provea y mande lo que fuere servido todo lo qual lei y notifique al dicho sargento mayor Francisco de Ledesma en su persona que lo oyo y firmo conmigo siendo presentes por testigos Ignasio de Ledesma y Jasinto de Vilches que lo firmo el que supo. Don Manuel de Zevallos Neto y Estrada. Francisco de Ledesma. Ignasio de Ledesma.

[Al margen: Autto]

En la ciudad de Cordova en siete diaz del mes de nobiembre de mill y seisientos y nobenta y tres años el capitan don Manuel de Zevallos Neto y Estrada alguazil mayor propietario de esta dicha ciudad y juez de comision nombrado por el señor doctor don Antonio Martinez Luxan de Vargas del consejo de su magestad su oydor mas antiguo de la ciudad de La Plata y vizitador general de esta provincia del Tucuman para la execusion de las sentensias dadas por dicho señor oydor contra los vezinos feudettarios de esta dicha çiudad dijo que atento a que su merced se hallava de buelta de los parajes del Totoral. Pichana y los demas pueblos de indios donde fue a executar dichas sentensias y le es presiso pasar a los demas pueblos y estansias de este rio Primero, Se [19v]gundo, Tersero, Quarto y valle de Calamuchita a dar cumplimiento a dichas sentensias mando se les notifique a todos los vezinos feudetarios que reziden en dichos partidos se hallen en los dichos sus pueblos y estansias para dar cumplimiento a dichas sentensias, reputando el tiempo que podra estar en ellas con la salida que haze de esta ciudad a diez del corriente coxiendo por este rio abajo Primero, pasando al Segundo y de el al Sause del capitan Pedro Diez y de alli vaxando para el valle de Calamuchita que lo mas que podra tardar en hallarse en los paraxes mas dilatados sera dentro de un mes con apersevimiento que pasado dicho termino no haviendo paresido su merced reserva probeer executando dichas sentensias y todo lo demas que a su merced tocare y les parara todo entero perxuisio como si presente fuesen asi se les nottifique y lo firmo. Don Manuel de Zevallos Neto y Estrada. Ante mi. Thomas de Salas escrivano de su magestad.

[Al margen: Notificacion]

En Cordova en el dicho dia siete de nobiembre del dicho año notifique el auto de susso al capitan don Sevastian de Carranza y Luna alcalde de la santa hermandad y vezino feudetario de esta dicha ciudad en su persona que lo oyo doy fee. Thomas de Salas escrivano de su magestad.

[20r] [Al margen: Otra]

En Cordova en el dicho dia siete de nobiembre de dicho año notifique el auto de esta otra parte al capitan Cristobal de Funes vezino feudetario de esta dicha ciudad en su persona que lo oyo doy fee. Thomas de Salas escrivano de su magestad.

[Al margen: Otra]

En Cordova en doze de nobiembre de dicho año notifique el auto de esta otra parte al sargento mayor Sevastian de Arguello vezino feudetario y fiel executor de esta dicha ciudad en su persona que lo oyo doy fee. Thomas de Salas escrivano de su magestad.

[Al margen: Otra] 
En Cordova en doze de nobiembre de dicho año notifique el auto de suso como en el se contiene al capitan Miguel de Vilches vezino feudetario de esta dicha ciudad en su persona que lo oyo doy fee, siendo testigos el sargento mayor Sevastian de Arguello fiel executor y Juan Ferreira Thomas de Salas escrivano de su magestad.

[Al margen: Auto]

En el Rio abajo de la ciudad de Cordova en la estansia y tierras del ayudante general Pedro de Suasnabar sinco leguas poco mas o menos de ella y en su juridision en catorze dias del mes de nobiembre de mill y seisientos y nobenta y tres años yo el capitan don Manuel de Zevallos Neto y Estrada alguazil mayor y juez nombrado por el señor doctor don Antonio Martinez Luxan de Vargas del consejo de su magestad y su oydor [20v] mas antiguo de la real audiensia de La Plata vezitador general de esta provinsia de Tucuman por expesial comision de su magestad para la execusion de las sentensias dadas por dicho señor vezitador general a los encomenderos de esta juridision. Y por lo que toca a la dada contra el dicho Pedro de Suasnabas encomendero y contra Pedro de Suasnabas su hijo como administrador de estos indios en la dicha ciudad de Cordova en diesiseis del mes de abril de este presente año de nobenta y tres vine a esta dicha estansia con asistensia del capitan Juan Lopez de Fuente Seca rexidor y protetor general de los naturales de la dicha ciudad, y por no haver hallado en esta dicha estansia al dicho encomendero y haverme informado se alla ausente, en la ciudad de Mendoza Reino de Chile y el dicho administrador su hijo en el rio Terzero segun lo a echo doña Maria Roza de Carranza muger lijitima del dicho administrador. Mando en cumplimiento de dicha sentensia, se haga la vista de ojos y se reconosca el sitio de tierras que se refiere y tiene menzionado el dicho administrador con asistencia de dicho [21r] protetor general y fecho rezerbo prover de justicia. Y por lo que toca al interes de los indios de los ocho pesos que a cada uno se les a mandado dar por el tiempo que an servido al dicho encomendero con los ocho pesos mas que se mandan dar al indio Francisco por el agravio de los asotes se les notifique a dichos indios parescan ante mi y declaren en dicha razon si estan pagados por el dicho administrador y fecho rezerbo probeer lo que conbenga asi lo provey mande y firme por ante mi y testigos a falta de escrivano. Don Manuel de Zevallos Neto y Estrada. Testigo. Juan Lopez de Fuente Seca. Don Pedro Ariaz de Sabedra.

[Al margen: Señalamiento de tierras a los indios de Pedro de Suasnabas]

En la dicha estansia del ayudante general Pedro de Suasnabas juridision de la çiudad de Cordova sinco leguas de ella poco mas o menos en catorse dias del mes de nobiembre de mill y seisientos y nobenta y tres años yo el capitan don Manuel de Zevallos alguazil mayor y juez de comision nombrado por el señor doctor don Antonio Martinez Luxan de Vargas del consejo de su magestad y su oydor mas antiguo de la real audensia de la ciudad de La Plata y vezitador general de esta provinsia de Tucuman por expesial comision de su magestad en cumplimiento del auto por mi [21v] proveydo oy dia de la fecha y con asistensia del capitan Juan Lopez de Fuente Seca rexidor y protetor general de los naturales y de los testigos de suso escriptos hize la vista de ojos y reconosimiento del sitio y tierras en que al presente estan sitiados los indios de esta encomienda con su rancho y chacras las quales hallamos ser frutiferas y comodas para sus aprovechamientos por tener tierras de pan llevar y con el agua sufisiente por caer sobre este rio Primero y en su conformidad y con asistensia de Matheo y Juan indios de esta dicha encomienda que al presente hallamos en ella y en atension a que el numero de dichos indios no pasan de quatro en cumplimiento de lo mandado por dicho señor oydor y vezitador general mande se les enterase un quarto de legua en quadro a todas partes para cuya execusion medi un cordel de cañamo de sinquenta baras y haviendo reconosido los linderos que dividen las tierras que tocan al dicho encomendero y a los herederos de doña Agustina de Aguilar y de Geronimo de Bustamante su marido difuntos que dicho lindero, es el paso viejo de carretas que iva desde dicha [22r] ciudad de Cordova al rio Segundo quedando las casas que fueron del dicho Geronimo de Bustamante y de 
doña Agustina de Aguilar difuntos como dicha cuadra poco mas o menos rio abajo de dicho paso, y cogiendo desde el rio arriba desde un sauze que estta a la orilla de dicho passo donde hize labrar una cruz para que con dicho paso sirba de lindero y desde el rio arriba de midieron treinta cuerdas de dichas zincuenta baras que hazen un mill y quinientas que son las que pertenezen a dicho cuarto de legua segun lo acostumbrado en esta jurisdicion el cual termino sobre dicho rio frente de un paso que llaman comunmente del Escuritto[?] que esta de la otra banda y de estas manda poner otro mojon y desde el coxiendo el rumbo del norte cuarta al nordeste hazia la savanna se midieron otras treinta cuerdas de dichas cinquenta baras que terminaron sobre una loma baja que esta entre el camino real que da al dicho rio Segundo y pasa por junto a las casas de los dichos Geronimo de Bustamante y doña Agustina de Aguilar y el que sale de la estancia del dicho en[22v]comendero que iba rio abaxo al zerro de arenas y se incorpora con el real que vaja de la dicha ciudad de Cordova y por lindero un arbol de chañar que esta en dicha loma mande hazer una cruz. Y desde el bolvi al dicho paso antiguo y primer lindero de esta medizion y desde la orilla del rio azia la savana coxiendo el rumbo del norte cuarta al nordeste se midieron otras treinta cuerdas de dichas zincuenta baras que pasaron el dicho camino real de carretas que sale de la dicha estancia del encomendero que iba al dicho zerro de arena adonde mande poner otro mojon de un palo de espinillo con lo cual quedaron medidas y amojonadas las dichas tierras de un cuarto de legua en cuadro; y en conformidad de su asignazion las declaro por tierras y reduzion de los dichos indios debajo de los linderos y moxones de suso referidos para que las ayan y tengan por suyas propias y gosen de ellas en todo aquello que fuere de su utilidad y combeniencia en cumplimiento de leyes y ordenanzas reales y en su virtud le di possession de dichas tierras a un inddio llamado Matheo [repetido y tachado: llamado Matheo] de esta dicha encomienda por si y en nombre de los demas que al pre[23r]sente son y en adelante fueren la qual se la di en nombre de su magestad real actual corporal yuri domini velquasi cojiendole de la mano y paseandole por ellas y el dicho indio Matheo en señal de que la aprehendia y tomava por si y en nombre de los demas indios de esta encomienda arranco iervas e hizo otros aççtos de posesion y mando a los que presentes estavan se las dexasen libres y desenvarasadas y de como asi, tomo la dicha posesion como a las doze del dia sin contradision de persona alguna me pidio el dicho protetor general en nombre de sus partes se lo diese por testimonio e yo el dicho juez se lo doy por testimonio en quanto puedo y a lugar de derecho, de haver sido y pasado como dicho es, y en su conformidad mando a todas y qualesquier personas de qualquier estado calidad y condision, que sean no sean osados a quitar ni mober los dichos mojones ni inquieten ni perturben a los indios de esta encomienda de la dicha posesion so las penas [23v] [repetido: so las penas] dispuestas por derecho y de dosientos pesos aplicados camara de su magestad en que desde luego les doy por incursos y condenados lo contrario haziendo. $Y$ el dicho encomendero y administrador en su nombre dentro de seis meses de la fecha de esta asignasion cumpla con hazer capilla en las tierras de esta redusion como lo manda el dicho señor vezitador general devajo de las penas contenidas por dicha sentensia. Y por lo que toca a las pagas mandadas hazer, a dichos indios haviendo paresido ante mi y dicho protetor general, el dicho Matheo indio dijo no se le an pagado los ocho pesos que le mando dar el dicho señor oydor por servisio que a hecho a dicho su encomendero. $Y$ otro indio llamado Juan dijo que a resevido a quenta de dichos ocho pesos de mano de dicho administrador dos varas y media de vayeta a doze reales y que se le restan deviendo quatro pesos y dos reales, y en su conformidad y de no saber si estan pagados Francisco [24r] y Pasqual indios de esta encomienda que estan ausentes al presente mando se le notifique al dicho Pedro de Suasnabas su administrador paresca en la dicha ciudad de Cordova ante mi dentro de tersero dia de la notificasion y cumpla con hazer la dicha capilla dentro del dicho termino asignado y a pagar a los dichos indios lo mandado por dicho señor oydor y vezitador general, con apersevimiento que el termino pasado y no haviendo cumplido rezerbo proveer de justisia y de lo de en esta razon obrado, se remita testimonio a costa de dicho administrador a dicho señor oydor y vezitador general, para que le conste. Asi lo provey mande y 
firme por ante mi y testigos siendolo presentes el capitan don Pedro Arias de Saabedra vezino feudetario, Ramon de Quiroga y el ayudante Nicolas Xuares que lo firmaron conmigo y dicho protetor general a falta de escrivano. Don Manuel de Zevallos Neto y Estrada. Juan Lopez de Fuente Seca. Don Pedro Arias Sabedra. Nicolas Xuarez. Testigo. Ramon de Quiroga.

[24v] [Al margen: Auto para Ramon de Quiroga]

En la estansia del sargento Ramon de Quiroga juridion [sic] de la ciudad de Cordova siete leguas de ella, poco mas o menos en quinze diaz del mes de nobiembre de mill y seisientos y nobenta y tres años yo el capitan don Manuel de Zevallos Estrada alguazil mayor y juez nombrado por el señor doctor don Antonio Martinez Luxan de Vargas del consejo de su magestad y su oydor mas antiguo de la real audiensia de La Plata vezitador general de esta provinsia de Tucuman por expesial comision del Rey nuestro señor para la execusion de las sentensias dadas a los encomenderos de esta juridision y por lo que toca a la pronunsiada contra el dicho Ramon de Quiroga como administrador perpetuo que es, de los indios calchaquiez, que tiene proveida por dicho señor vezitador general en la ciudad de Cordova en diesiseis diaz del mes de abril de este presente año de nobenta y tres vine a esta dicha estancia adonde tiene asitiados estos dichos [25r] indios de consentimiento de dicho señor oydor y vezitador general por haverle representado los dichos indios despues de pronunsiada dicha sentensia, que querian estar en estas dichas tierras por tenerlas cultivadas y pobladas teniendo sus aprovechamientos y para la aberiguasion de si estan pagados los indios e indias que le an servido a los barones a seis pesos y quatro a las mugeres vine a esta dicha estansia con asistensia del capitan Juan Lopez de Fuente Seca rexidor y protetor general, de los naturales y mande pareser ante mi y dicho protetor general a los indios e indias de esta administrasion y les pregunte quienes avian servido al dicho administrador y dijeron un indio llamado Juan y una india llamada Ignes, haverle servido y que estan pagados de lo mandado por dicho señor oydor en dicha sentensia. Y por lo que toca a Francisco indio ausente [entrelíneas: declaro su madre llamada Isavel] haverle visto pagar los seis pesos en plata que le dio dicho administrador. Y por estar asi mismo ausente otro indio de esta administrasion llamado Francisco casado con Pasquala india y no haverse po[25v]dido aberiguar si esta pagado de dichos seis pesos le rezervo su derecho a salvo para que de no estar pagado los demande, y para que de ello conste lo firme con dicho protetor y testigos a falta de escrivano. Don Manuel de Zevallos Neto y Estrada. Juan Lopez de Fuente Seca. Ramon de Quiroga. Testigo Pedro de Quiroga.

[Al margen: Autto]

En el pueblo de Guamacha, de los indios de la encomienda del capitan Miguel de Vilches y Montoya juridision de la ciudad de Cordova quinze leguas de ella poco mas o menos, en diesisiete diaz del mes de nobiembre de mill y seisientos y nobenta y tres años. Yo el capitan don Manuel de Zevallos Neto y Estrada alguazil mayor y juez nombrado por el señor doctor don Antonio Martinez Lujan de Vargas del consejo de su magestad y su oydor mas antiguo de la real audiensia de La Plata vezitador general de esta provincia de Tucuman por expesial comision de su magestad para la execusion de las sentensias dadas a los vezinos feude[26r]tarios de esta juridision y por lo que toca a la pronunsiada en dicha ciudad de Cordova en veinte dias del mes de abril de este presente año de mill y seisientos y nobenta y tres contra el dicho capitan Miguel de Vilches y Montoya que se le notifico por el escrivano reseptor de visita, mando se le notifique paresca ante mi y el protetor general de los naturales por lo que toca al interez de los indios y que se haga la liquidasion mandada hazer, por dicho señor vesitador general del tiempo que le an servido con asistensia de dicho protetor y partes interesadas, y para que asi mismo se aberigue si estan pagados de los quatro pesos que se mandan dar a tres indias que le an servido y a los indios Pablo y Garsia por lo que resulto de malos tratamientos. Y asi mismo mando que dentro de segundo dia se redusgan todos los indios e indias muchachos y muchachas de esta encomienda que tiene el 
dicho encomendero en su estansia a este pueblo de Guamacha por no haver hallado en el, mas que tan solamente a don Thomas de Abibilie, curaca de dichos indios y a Juan casado y otro indio llamado Alonso natural de Santiago [26v] del Estero, casado con Luzia india de esta encomienda y otro indio llamado Martin de dicha ciudad de Santiago casado con Silvestra india de esta encomienda en cumplimiento, de dicha sentenzia lo qual cumpla pena de sinquenta pesos aplicados camara de su magestad y de que prosedere a las demas diligensias que conbengan corriendo por su quenta los diaz y salarios que pudieren correr por su demora, a mi dicho juez como al dicho protetor general. Y por lo que toca a la capilla que manda dicho señor vezitador general haga dicho encomendero cumpliendo con el tenor de la hordenanza veinte de esta provinsia atento a que e reconosido con dicho protetor general, a vista de ojos, no haverse comensado a hazer dicha capilla en este dicho pueblo de Guamacha por el dicho encomendero que devio tener hecha dentro de los seis meses asignados por dicho señor oydor y vezitador general como consta de la comision a mi dada, cuyo termino es cumplido a veinte del mes de otubre proxsimo pasado de este año en cuya atension le devo declarar y declaro por incurso en las penas contenidas en la dicha [27r] hordenanza veinte y mando que se de quenta a dicho señor vesitador general sacandose testimonio de este auto y de lo que en su razon se obrare, a costa de dicho encomendero para que con su vista se sirva de proveer lo demas que conbenga. Asi lo provey mande y firme por ante mi y testigos a falta de escrivano. Don Manuel de Zevallos Neto y Estrada. Testigo. Juan Lopez de Fuenteseca. Testigo. Pedro Gallegos del Sueldo.

[Al margen: Notificacion]

En el pueblo de Guamacha en diesisiete del mes de nobiembre de seisientos y nobenta y tres años yo el dicho alguazil mayor y juez ley notifique e hize notoria la comision a mi dada por el señor oydor y vezitador general y en su conformidad, el auto de este otro pliego por mi proveido al capitan Migel de Vilches y Montoya vezino encomendero de los de este dicho pueblo en su persona que lo oyo y lo firmo conmigo. Don Manuel de Zevallos Neto y Estrada. Miguel de Vilchez y Montoya.

[Al margen: Liquidasion de quenta y revision de los indios del pueblo de Guamacha]

En el dicho pueblo de Guamacha encomienda del capitan Migel de Vilches y Montoya en diesinuebe dias del mes de nobiembre de mill y seisientos y nobenta y tres años en cumplimiento del auto por mi proveydo en diesisiete de este presente mes y año que se halla notificado al dicho $[27 \mathrm{v}]$ encomendero trajo a mi presensia y del protetor general tres indios llamados Domingo, Juan y Pablo que an servido al dicho capitan Miguel de Vilchez y Montoya su encomendero y aviendose ajustado y liquidado su quenta de cada uno del tiempo que le a servido rezulto dever el dicho encomendero lo siguiente. Al indio Domingo quarenta y quatro pesos y quatro reales. A Juan veinte y quatro pesos y dos reales. $\mathrm{Y}$ al indio Pablo sesenta y tres pesos y siete reales. Cuyas partidas inportan siento y treinta y dos pesos y sinco reales que deve pagar el dicho capitan Miguel de Vilches y Montoya a los dichos tres indios por el tiempo que le an servido, hasta el de la vezita los quales mando al dicho encomendero les aga la dicha paga por en mi presensia y la de dicho protetor general, dentro de segundo dia con apersivimiento que el termino pasado proveere de justicia, y asi se le notifique. Y por lo que toca a los quatro pesos que se le mandaron dar los indios Pablo y Garsia y a las tres indias que le an servido llamadas Maria Geronima y Silvestra, atento a que an confezado estar pagados cada uno de los dichos quatro pesos de mano del dicho su encomendero le declaro por libre de esta satisfasion [28r] y en quanto a la redusion mandada hazer en cumplimiento de ello, sertifico yo dicho juez en quanto puedo y a lugar de derecho que trajo el dicho encomendero, a este dicho pueblo a mi presensia y de dicho protetor, y de los testigos de iuso las piezas siguientes. A Juan indio viudo con dos hijos la una llamada Bartholina, de hedad al pareser de seis años y a Francisco de quatro años, y declaro tener otros dos hijos la una llamada Petrona y el otro Gabriel (este de dos años y la hixa de diez que no trajo 
por estar enfermos) media legua de este dicho pueblo en un rancho de una mestiza llamada Francisca muger de Juan Barrera. A Domingo casado con Pascuala con un hixo de pechos llamado Lorenzo. A Pablo indio viudo con una hija llamada Magdalena de tres años. Y a Garsia muchacho soltero de quinze años hijo de Cristobal indio ausente al presente de esta encomienda. A los quales dichos indios muchachos y muchachas con los demas que estan redusidos en este dicho pueblo con todos los demas, que paresieren y estan ausentes, mando, se asitien y mantengan en este dicho pueblo de Guamacha, para que vivan y residan juntos sin salir de el, mas que a las cosas prevenidas por reales hordenansas, sin que pueda el encomendero sacarlos ni usar de su servi[28v]sio personal segun lo manda dicho señor oydor y vezitador general devajos de las penas y apersevimientos contenidos en dicha sentensia que le esta notificada. Para cuyo cumplimiento estando presentes el dicho encomendero y demas indios e indias de esta redusion y encomienda les lei y notifique lo de suso contenido en sus personas que dijeron lo oyan y que estan prontos a cumplir con lo que se les manda cada uno por lo que les toca y para que de ello conste lo firme yo dicho juez con dicho protetor y encomendero por ante mi y testigos presentes a todo lo referido a falta de escribano, el alferez Thomas Ferreira, Blas Ferreira y el sargento Ramon de Quiroga de ello doy fee. Don Manuel de Zevallos Neto y Estrada. Juan Lopez de Fuente Seca. Miguel de Vilches y Montoya. Thomas Ferreira testigo. Blas Ferreira. Ramon de Quiroga.

[Al margen: Auto]

En el pueblo de Cayasacate de los indios de don Francisco de Ledesma juridision de la ciudad de Cordova en veinte y un dias del mes de nobiembre de mill y seisientos y nobenta y tres años [29r] yo el capitan don Manuel de Zevallos Estrada alguazil mayor y juez nombrado por el señor doctor don Antonio Martinez Luxan de Vargas del consejo de su magestad, su oydor mas antiguo de la real audiensia de La Plata vezitador general, de esta provinsia por expesial comision del Rey nuestro señor para la execusion de las sentensias dadas a los encomenderos de esta juridision. $Y$ en atension a que el capitan Miguel de Vilchez y Montoya es deudor a Domingo indio de quarenta y quatro pesos y medio, a Juan de veinte y quatro pesos y dos reales, a Pablo de sesenta y tres pesos y siete reales, en que le alcansaron por el servisio personal que le an hecho hasta el tiempo de la vezita como consta de la liquidasion que se hizo con el protetor general encomendero y partes interesadas ante mi dicho juez cuyas cantidades inportaron siento y treinta y dos pesos y sinco reales, que le mande pagar al dicho encomendero dentro de segundo dia cuyo termino es pasado y no a cumplido con la dicha satisfasion y para que se haga mando se le notifique al dicho encomendero por ultimo a apersevimiento luego a la hora de la notificasion de, y pague en mi [29v] presensia y la de el dicho protetor a los dichos indios las dichas cantidades en que le an alcasado con mas sinquenta y seis pesos que deve a mi dicho juez y protetor general por los salarios de quatro pesos a cada uno por dia en que nos emos ocupado los dos dias de venida a su pueblo de Guamacha dos de estada en el para la redusion de los indios que tenia en su estansia y liquidasion de quentas que se hizo con mas otro dia en que nos ocupamos para esta satisfasion y los dos restantes para la vuelta. $Y$ de no hazerlo se trave execusion en vienes suyos propios y valiosos hasta la concurrente cantidad de suso referidas dezima y costas y este auto sirva de mandamiento en forma asi lo provey mande y firme por ante mi y testigos a falta de escribano. Don Manuel de Zevallos Neto y Estrada. Testigo. Juan Lopez de Fuente Seca. Testigo. Pedro de Suasnabas.

[Al margen: Pagas hechas por Miguel de Vilchez]

En la estansia de San Francisco del capitan Miguel de Vilches y Montoya juridision de la ciudad, de Cordova diesiocho leguaz de ella poco mas o menos en veinte y dos dias del mes de nobiembre de mil y seisientos y nobenta y tres años ante mi el dicho alguazil mayor [30r] y juez de comision y de los testigos de iuso estando presente el dicho protetor general de los naturales el dicho capitan Miguel de Vilchez y Montoya hizo las pagas de los siento y treinta y dos pesos y sinco 
reales que devia [Al margen: paga 132 pesos 5 reales], los quarenta y quatro y medio de ellos al indio Domingo veinte y quatro pesos y dos reales al indio Juan, y los sesenta y tres pesos y siete reales al indio Pablo todos en ropa de pañete, vayeta y lienzo a presios corrientes a satisfasion de los interezados y dicho protetor general con mas sinquenta y seis pesos que nos pago a mi dicho juez y protetor que importaron los siete diaz que nos emos ocupado en la estada venida y buelta como consta del dicho auto en cuya virtud, doy por libre al dicho encomendero de una y otra paga y para que de ello conste lo firme con dicho protetor y testigos que se hallaron presentes el capitan don Joseph de Carranza Bartolome Xuarez de Puelles y Pedro de Suasnabar a falta de escrivano de ello doy fee. Don Manuel de Zevallos Neto y Estrada. Juan Lopez de Fuente Seca. Testigo don [30v] Joseph de Carranza. Testigo. Bartolome Xuarez de Torrez. Testigo. Pedro de Suasnabar.

[Al margen: Auto]

En la estansia del alferez Thomas Ferreira en el rio Sigundo juridision de la ciudad de Cordova diesiseis leguas de ella poco mas o menos en diesinuebe diaz del mes de nobiembre de mil y seisientos y nobenta y tres años yo el capitan don Manuel de Zevallos alguazil mayor y juez nombrado por el señor doctor don Antonio Marttinez Luxan de Vargas del consexo de su magestad, y su oydor mas antiguo de la real audiensia de La Plata vezitador general de esta provinsia de Tucuman por expesial comision de su magestad, para la execusion de las sentensias dadas a los vezinos encomenderos de esta juridisccion y por lo que toca a la pronunsiada contra el dicho alferez Thomas Ferreira su data en dicha ciudad, de Cordova en catorze del mes de abril de este presente año de nobenta y tres mando al dicho alferez Thomas [31r] Ferreira por lo que toca al interes de los indios que se les manda pagar por dicha sentensia a seis pesos a cada uno. Por el tiempo que le an servido y a la india Maria tres pesos los traiga ante mi y su protetor general para aberiguar si estan pagados de ellos y respeto de no tener pueblo y mandar en dicha sentensia dicho señor oydor y vezitador general que todos los indios e indias de esta encomienda se redusgan al pueblo de Guamacha que es el mas sercano y en [entrelíneas: su] execusion y cumplimiento mando asimesmo al dicho alferez Thomas Ferreira que dentro de segundo dia de la notificasion de este auto redusga a los dichos indios e indias muchachos y muchachas de su encomienda al dicho pueblo de Guamacha para que los dichos indios puedan sembrar libremente y tener otras granjerias para sustentarse. Todo lo qual cumpla pena de sinquenta pesos aplicados camara de su magestad y de que se prozedera a las demas diligensias que convengan corriendo por su quenta los diaz y sa[31v]larios que pudieren correr por su demora a mi dicho juez y protetor general. Asi lo provei y mande y firme por ante mi y testigos a falta de escribano. Don Manuel de Zevallos Neto y Estrada. Testigo. Juan Lopez de Fuente Seca. Testigo. Ramon de Quiroga.

[Al margen: Notificacion]

Luego encontinenti yo el dicho juez notifique el auto de suso por mi proveydo, al alferez Thomas Ferreira vezino feudetario en su persona que dixo lo oya y que esta pronto a cunplir con lo que se le manda y lo firmo conmigo doy fee. Don Manuel de Zevallos Neto y Estrada. Thomas Ferreira.

[Al margen: Redusion de los indios de Thomas Ferreira a este pueblo de Guamacha]

En el pueblo de Guamacha de los indios del capitan Miguel de Vilchez y Montoia en diesinuebe diaz del mes de nobiembre de mill y seisientos y nobenta y tres años en cunplimiento del auto por mi proveydo oy dia de la fecha, ante mi dicho juez de comision y protetor general de los naturales paresio el alferez Thomas Ferreira vezino feudetario, y trajo a Geronimo Alonzo y a Juana y Bernarda mugeres de los dichos y a Maria soltera con un hijo de pechos llamado Hernando y a Justina hija del dicho Alonsso y de la dicha Bernarda su muger de hedad de [32r] seis meses que declararon ser todos los indios e indias muchachos y muchachas de esta 
encomienda eszepto Lazaro indio casado con hijos que dijo el dicho encomendero estar ausente en el rio Primero de Cordova que no a podido reduzir por tener pleito pendiente con el ante la justisia hordinaria de dicha ciudad de Cordova pretendiendo el dicho indio Lazaro no ser de esta encomienda. Para efecto de que sean redusidos a este dicho pueblo de Guamacha en cunplimiento de la sentensia pronunsiada por dicho señor vizitador general para que los dichos indios puedan sembrar libremente y tener otras granxerias para sustentarse y pagar los tributos a su encomendero en conformidad, de la tasa hecha en las hordenansas de esta provinsia teniendolas por su redusion para que vivan juntos sin salir del mas que a las cosas prevenidas por reales ordenansas, sin que pueda el encomendero sacarlos ni usar de su servisio personal devajo de las penas y apersevimientos contenidos en leies y hordenansas reales todo lo qual ley y notifique yo el dicho juez de comision asi, al dicho encomendero como a dichos [32v] indios e indias de suso referidos en sus personas que dixeron lo oyan y que estan presto a cumplir con lo que se les manda. Y por lo que toca al interez de los indios de los seis pesos que se les mandan pagar por dicho señor oydor y vezitador general y tres pesos a la india Maria por el tiempo que an servido declararon los dichos Geronimo y Alonzo indios y la dicha india Maria estar pagados de dichas cantidades de mano de dicho su encomendero por haverlos rezevido en dicha ciudad de Cordova luego que salio la dicha sentensia y por en presensia de dicho protetor general quien lo confeso asi, en cuya atension declaro al dicho encomendero por libre de esta satisfasion, y mando se remita testimonio de estos autos a dicho señor vezitador general a costa del dicho encomendero y para que de ello conste lo firme con dicho protetor y encomendero y testigos a falta de escrivano siendolo presentes Blas Ferreira de Azevedo y el sargento Ramon de Quiroga de ello doy fee. Don Manuel de Zevallos Neto y Estrada. Juan Lopez de Fuente Seca. Thomas Ferreira. Blas Ferreira de Azevedo. Testigo. Ramon de Quiroga.

[Al margen: Señalamiento de tierras a los indios de don Francisco de Ledesma]

En las tierras de Caisacate en el rio Segundo juridision de la çiudad [33r] de Cordova diesisiete leguas de ella poco mas o menos en veinte y un diaz, del mes de nobiembre de mill y seisientos y nobenta y tres años yo el capitan don Manuel de Zevallos Neto y Estrada, alguazil mayor propietario y juez nombrado por el señor doctor don Antonio Martinez Luxan de Vargas, del consexo de su magestad y su oydor mas antiguo de la real audiensia de la çiudad de La Plata vezitador general de esta provinsia de Tucuman por expesial comision del Rey nuestro señor para la execusion de las sentensias dadas a los vezinos encomenderos de esta juridision y por lo que toca a la proveyda contra el capitan don Francisco de Ledesma en dicha çiudad de Cordova en veinte diaz del mes de abril de este presente año de nobenta y tres que se le halla notificada vine a estas dichas tierras con asistensia del capitan Juan Lopez de Fuente Seca Rexidor propietario y protetor general de los naturales para la asignasion de tierras que se a de aser a los yndios de esta encomienda, en virtud de la transasion que se a hecho con los herederos del maese de campo Pedro Tello de Sotomayor que aprobo el dicho señor oydor y vezitador gene[33v]ral en el pleito que se avia formado, ante su señoria por su decreto proveido en dicha çiudad de Cordova por el mes pasado de abril de este dicho año de nobenta y tres en que se manda se les de, a dichos indios media legua de tierras frente al rio y otra media legua en quadro para la savana a la vanda del norte, aviendo paresido ante mi dicho juez y de los testigos de iuso escriptos el alferez Blas Thello de Sotomayor, uno de los hijos y herederos de el dicho maese de campo Pedro de Sotomayor por si, y en nombre de los demas sus hermanos, hizimos vista de ojos del lindero que dividen las tierras que fueron del dicho su padre, de la parte del dicho rio abaxo hallandose, presente, a esta diligensia los capitanez Miguel de Vilchez y don Diego de Santillan como interesados en las tierras que poseen, de la parte del dicho rio abajo a quienes yo dicho juez, site para el dicho efecto y [entrelíneas: en] su conformidad, el dicho capitan Miguel de Vilchez hizo exibision ante mi dicho juez estando presente, el dicho Blas Tello [34r] de un compromiso que hisieron el dicho maese de campo Pedro Thello y capitan Francisco de Vilches sus padres en que consta el lindero 
que dividen sus tierras en este rio Segundo, de la parte del norte, que es un paso antiguo de carretas que llaman de Cosme, que esta frente a unas tapias viejas y pencas de tunas que fueron de Hernando de Tinoco y caen a la otra vanda del dicho rio y parte del sur y en atension de haver conbenido las partes en presensia de dichos testigos en el dicho lindero que dividen sus tierras yo dicho juez mande se hiziese el dicho entero de la dicha media legua en quadro y coxiendo desde el dicho paso de carretas y sobre el, a la parte de avajo mande poner un palo de algarrobo por lindero y aviendo medido un cordel de cañamo, de sinquenta varas y coxiendo el rumbo del oeste, quarta al nordeste rio arriva se midieron sesenta cuerdas de dichas sinquenta varas que hazen la dicha media legua de tierras que terminaron dentro de una sanja que servia de serco a las chacras que fueron del dicho maese de campo Pedro Tello cayendo sobre un sauce [34v] a la orilla del rio y en el mande labrar una cruz para que sirviese de lindero el qual dicho sauce, y lindero cayo dentro de la dicha chacra, pasada la dicha sanja como dos quadras poco mas o menos. Y cojiendo desde el dicho sauce, y lindero a la savana corriendo el rumbo del norte quarta al norueste se midieron otras sesenta cuerdas de dichas sinquenta varas que hazen tres mill que son las que pertenesen a la dicha media legua que terminaron a la orilla de un brazo de arroyo que sale del rio antiguo de Ilasta, adonde mande poner otro mojon. Y aviendo buelto al dicho paso que llaman de Cosme y primer lindero de esta midision cojiendo el rumbo a la savana del norte quarta a la norueste se medieron otras dichas sesenta cuerdas desde la orilla del rio que hazen otra media legua las quales terminaron en la campaña pasado un monte de chañar adonde mande poner otro mojon de un palo de algarrobo. Con lo qual quedaron medidas y amojonadas las dichas tierras de media legua en quadro y en con[35r]formidad, de su asignasion y del dicho decreto proveido por dicho señor oydor y vezitador general, las declaro por tierras y pueblo de los dichos indios y les anparo en ellas para que en lo de adelante las tengan en posesion y propiedad, devajo de los linderos y moxonez de suso referidos y en su virtud, le di posesion de dichas tierras a don Estevan de Aboyan curaca de los indios de esta encomienda por si, y en nombre de los demas indios que al presente son y en adelante fueren la qual se la di, en nombre de su magestad real acctual corporal iuri domini velquasi, en forma de derecho cojiendole de la mano y paseandole por ellas y el dicho curaca en señal de que la aprehendia y tomava por si, y en nombre de los demas indios de esta encomienda arranco iervas e hizo otros actos de posesion y mando a los que presentes estavan se las dejasen libres, y desembarasadas y de como asi, tomo la dicha posesion, sin contradision de persona alguna como a las tres y quatro de la tarde, me pidio el dicho protetor general, en nombre de sus partes se lo diese por testimonio y yo el dicho juez se lo doy en quantto [35v] puedo y a lugar de derecho de haver sido y pasado como dicho es, y en su conformidad mando a todas y qualesquier personas de qualquier estado calidad, y condision que sean no sean osados a quitar ni mober los dichos moxones ni inquieten ni perturben a los indios de esta encomienda que al presente son y en adelante fueren de la posesion de las dichas tierras so las penas dispuestas por derecho y de dosientos pesos aplicados camara de su magestad en que desde luego les doy por incursos y condenados, lo contrario haciendo. Y el dicho alferez Blas Tello de Sotomayor con los demas herederos del dicho maese de campo Pedro Tello su padre, otorgaran instrumento autentico, de las dichas tierras como lo manda el dicho señor oydor y vezitador general dentro de un mes a favor de los dichos indios para que en todos tienpos conste. Y por lo que toca a la fabrica de la capilla, la hara el dicho encomendero dentro de quatro meses como lo tiene ofresido en su escripto al dicho señor vezitador [36r] general, dentro de las tierras de suso deslindadas adonde se redusiran todos los indios e indias muchachos y muchachas de esta encomienda so las penas contenidas en la hordenanza veinte cuyo termino a de correr desde oy dicho dia de esta asignasion y en quanto al interez, de los indios en atension, de que el dicho don Francisco de Ledesma su encomendero se halla ausente de esta dicha juridision, y en la de Santiago del Estero en esta dicha provincia y abernos informado el dicho curaca a llevado consigo, a sinco indios de esta encomienda llamados Francisco, Matheo, Thomas, Lorenzo, y otro Lorenzo, y no poderse ajustar ni liquidar la quenta de lo que les puede dever por no estar 
presentes los interesados les dejo el derecho a salvo al dicho protetor para que pida lo que les convenga al derecho de sus partes, sobre que rezervo proveer de justisia y se remita testimonio a costa del dicho encomendero de estos autos al dicho señor oydor y vezitador general para que le conste, asi, lo provey y firme con las dichas partes y testigos siendolo presentes los alferez Thomas Ferreira y Francisco Ferreira [36v] Laso de la Vega a falta de escrivano de ello doy fe. Don Manuel de Zevallos Neto de Estrada. Juan Lopez de Fuente Seca. Blas Tello de Sotomayor. Miguel de Vilches y Montoya. Don Diego de Santillan. Testigo. Francisco Ferreyra Laso de la Vega. Thomas Ferreira.

[Al margen: Asignassion de tierras a los indios del capitan Xriptobal de Funez y Ludueña]

En la redusion y pueblo de los indios calchaquies del capitan Cristobal de Funez y Ludueña llamada San Joseph que esta en este rio Sigundo juridision de la çiudad de Cordova doze leguas de ella poco mas o menos en veinte y sinco diaz del mes de nobiembre de mill y seisientos y nobenta y tres años yo el capitan don Manuel de Zevallos Neto y Estrada alguazil mayor propiettario y juez nombrado por el señor doctor don Antonio Martinez Lujan de Vargas del conzejo de su magestad y su oydor mas antiguo de la real audiensia de La Platta vezitador general, de esta provinsia de Tucuman por expesial comision del Rey nuestro señor para la execusion de las sentensias dadas por dicho señor vezitador general a los encomenderos de esta dicha juridision. Por lo que toca a la pronunsiada en dicha ciudad de Cordova en onze del mes de abril de este presente año de nobenta y tres contra el dicho capitan Cristobal de Funez vine a este dicho pueblo ayer veinte [37r] y quatro del corriente con asistensia del capitan Juan Lopez de Fuente Seca rexidor y protetor general de los naturales y hallando en el al dicho encomendero le ley e hize notoria la comision a mi dada por dicho señor oydor y vezitador general y en cumplimiento de la dicha sentensia hizimos reconosimiento y vista de ojos de las tierras de esta redusion que les fueron señaladas por fin y muerte del maese de campo Geronimo de Funez y Ludueña su primer encomendero por adjudicasion que de ellas se le hizo ante la real justisia que dichos yndios an estado poseyendo y hallamos por los instrumentos y compra que de estas dichas tierras hizo el dicho maese de campo Geronimo de Funez a Juan Romero de Pineda y a doña Inez de la Jara su muger no tener frente al rio mas que tan solamente seis mill piez jumetricos que hazen dos mil varas y que no corresponden a quarto y medio de legua y tocarle a esta redusion mas cantidad de tierras por [entrelíneas: ser] el numero de sus indios mas de diez tributarios le requeri yo dicho juez al dicho capitan Cristobal de Funez y Ludueña su en[37v]comendero que en conformidad de dicha sentensia les asigne las sufisientes y a nuestra satisfasion dandoles las que les corresponden para que dichos indios tengan sus aprovechamientos con apersevimiento que de no hazerlo proveere del remedio conbiniente en utilidad de dichos indios. Lo qual oydo y entendido por el dicho encomendero ofrecio dar, ademas de los dichos seis mill pies otros tres mill piez jumetricos que lindan unos con otros, a la parte del dicho rio arriva con veinte mill piez que tiene a la savana a la parte del sur, que compro de Felisiano de Santillan y de doña Agustina de Pineda su muger todas las quales dichas tierras reconosidas por mi dicho juez y protetor general, con don Juan Pituala curaca de este dicho pueblo con otros indios de su redusion en atension a que son frutiferas y todas las que hazen frente a dicho rio de pan llevar, y que tienen una legua y seisientas y sesenta y seis baras y dos tersias de largo a la parte del sur, y media legua de ancho frente a dicho rio, segun consta de las escripturas y merzed [38r] que de todas ellas exsivio ante mi dicho juez y protetor el dicho encomendero y que los dichos indios estan contentos con ellas y las tienen pobladas y cultivadas con sementeras de trigo mais y otras legumbres y con el agua sufisiente por caer dichas tierras sobre el dicho rio Sigundo las declaro por vastantes y sufisientes para esta redusion y en su conformidad, aviendo sitado a Pedro Navarro Mexia como subsesor en el derecho de las tierras de Pedro de Soria que lindan con estas por la parte del rio abajo quien estando presente con otros sircunvezinos declararon por lindero que dividen estas tierras, un sauze, que esta a la orilla del dicho rio quedando a la parte del rio 
arriva un paso que llaman de Nieto y como tres quadras poco mas o menos del dicho sauze y lindero y desde [entrelíneas: dicho] sauze cojiendo el rumbo a la parte del sur, parte una laguna quedando dentro de las tierras de esta redusion, como quadra y media de dicha laguna poco mas o menos. Y aviendo medido un cordel de cañamo de sinquenta varas en presensia de los interesados y testigos de iusso, y coxiendo desde dicho sauze, y lindero adonde mande labrar una cruz rio arriva se midieron sesenta querdas de dichas [38v] sinquenta varas que hazen la dicha media legua de frente al rio que terminaron en un sauze, a la orilla de el, adonde mande labrar otra cruz, para que sirviese de lindero y coxiendo desde dicho sause y orilla del rio el rumbo del norte corriendo al sur, se midieron siento y treinta y tres querdas de dichas cinquenta varas con mas diesiseis varas y dos tersias que hazen los veinte [entrelíneas: mill] piez jumetricos que tocan a la merced de estas tierras que terminaron en la campaña adonde mande poner otro lindero quedando el camino real de carretas que va, de este rio a la estancia del Tala, dentro de estas dichas tierras y lindero de suso referido. Y cojiendo desde el, el rumbo del este, se midieron otras sesenta querdas de dichas çinquenta varas que hazen otra media legua las quales terminaron a la baxada de una cañada de un barrial adonde mande poner otro moxon que cayo del sur, al norte, frente al primer lindero de esta midision. Con lo qual quedaron medidas y amoxonadas estas [39r] dichas tierras en la cantidad y rumbos de suso referidos y en conformidad de su asignasion, las declaro por tierras y pueblo de estos dichos indios para que las tengan en posesion y propiedad, y en su virtud yo el dicho juez di posesion de estas dichas tierras al dicho curaca don Juan Piguala por si y en nombre de los demas indios que al presente son y adelante fueren de esta encomienda y se la di en nombre de su magestad real actual corporal iuri domini bel quasi, en forma y segun derecho coxiendole de la mano y paseandole por ellas y el dicho curaca en señal de que la haprehendia y tomava arranco iervas e hizo otros actos de posesion y mando a los que presentes estavan se las dejazen libres y desenbarazadas y de como asi, tomo la dicha posesion como a las quatro horas de la tarde sin contradision de persona alguna me pidio el dicho protetor general en nombre de sus partes se lo diese por testimonio y yo el dicho juez se lo doy en quanto puedo y a lugar de derecho de [39v] [repetido: de] haver sido y pasado como dicho es, y en su conformidad, mando a todas y qualesquier personas de qualquier estado, calidad y condision que sean, no sean osados a quitar ni mober los dichos moxonez ni inquieten ni perturben a los indios de esta encomienda que al presente son y en adelante fueren de la posesion de estas dichas tierras so las penas dispuestas por derecho y de dosientos pesos aplicados camara de su magestad en que desde luego les doy por incursos y condenados lo contrario haciendo. Y en su conformidad mando al dicho capitan Cristobal de Funez que dentro de un mez, otorgue instrumento publico ante el escrivano de cavildo para que en todos tiempos conste y que no saque el dicho encomendero a los indios e indias muchachos y muchachas de esta encomienda y redusion ni use de su servisio personal, devajo de las penas [entrelíneas: contenidas] por leyes y hordenanzas reales y por lo que toca al interez de los indios de los diez pesos que a cada uno de los que le an servido y [40r] quatro pesos a la india Catalina que se le mandan pagar en dicha sentensia en atension a que el dicho protetor general, y el dicho curaca don Juan Piguala y demas indios confesaron estar pagados de dicha cantidad, como la dicha india por haverlo hecho el dicho encomendero en dicha ciudad de Cordova al tiempo de la vesita en presensia de dicho protetor le declaro por libre de esta obligasion al dicho encomendero. $Y$ en quanto a la capilla que se le manda hazer dentro de quatro meses por dicha sentensia en atension a que no estava hecho el reconosimiento de estas tierras ni saber si eran las sufisientes, mando al dicho encomendero que dentro de los dichos quatro meses de oy dia de la fecha de esta asignasion, la haga en las tierras de esta redusion devajo de las penas contenidas, en la hordenanza veinte, con apersevimiento que el termino pazado y no haviendolo cumplido, le declaro por incurzo en la dicha pena contenida en la dicha hordenanza [40v] veinte lo qual se le notifique a dicho encomendero para que le conste y haviendolo fecho dixo que esta pronto a cumplir con lo que se le manda en este auto y remitase testimonio de el, a dicho señor oydor y vezitador general a costa del dicho 
encomendero para que con su vista se sirva de probeer lo demas que convenga. Asi, lo probey y firme con las partes, protetor y testigos que se hallaron presentes a todo lo referido el maese de campo don Juan Hordoñez del Aguila, el alferez Blas Ferreira, el theniente Pedro Vaez de Salas y Salvador Ferreira a falta de escrivano de ello doy fee. Don Manuel de Zevallos Neto y Estrada. Juan Lopez de Fuente Seca. Cristobal de Funez. Pedro Navarro Mexiga. Testigo Blas Ferreira de Azevedo. Testigo Pedro Vaez de Salas. Testigo don Juan Hordoñez del Aguila. Testigo Salvador Ferreira.

[Al margen: Asignasion de tierras a los indios del capitan Pedro Diez Gomez]

En el rio Quarto estansia y tierras del capitan Pedro Diez Gomez juridision de la ciudad de Cordova quarenta leguas de ella poco mas o menos en [41r] dos diaz del mes de diziembre de mil y seisientos y nobenta y tres años yo el capitan don Manuel de Zevallos Neto y Estrada Alguazil mayor propiettario y juez nombrado por el señor doctor don Antonio Martinez Luxan de Vargas del conzejo de su magestad, su oydor mas antiguo de la real audiensia de La Plata y vezitador general de esta provinsia de Tucuman por expezial comision del Rey nuestro señor para la execusion y cumplimientto de las sentensias dadas a los encomenderos de esta juridision y por lo que toca a la proveyda contra el dicho capitan Pedro Diez Gomez en dicha ciudad de Cordova en quinze diaz de el mes de abril de este presente año de nobenta y tres con asistensia del capitan Juan Lopez de Fuente Seca rexidor y protetor general de los naturales vine a esta dicha estansia y haviendo hallado [entrelíneas: en ella] al dicho encomendero ayer primero del corriente yo el dicho juez le ley e hize notoria la comision a mi dada por dicho señor vezitador general y en su cumplimiento hizimos reconosimiento y vista de oxos de las tierras que asigna a los indios tobas fronterizos desnaturalizados [41v] de la provincia del Chaco que posee por encomienda las quales hallamos ser frutiferas y comodas para aprovechamiento, de dichos yndios con el agua sufisiente, por caer sobre este dicho rio Quarto, y en atension de que los indios de esta encomienda, son seis con Andres ausente, al presente, mande, en cumplimiento de los proveydo por dicho señor oydor y vezitador general se les enterasen media legua de tierras en quadro frente al rio de la parte del norte, para lo qual se midio en mi presensia y de los testigos de iusso con asistensia de las partes un cordel de cañamo de sinquenta varas y desde una esquina que haze el dicho rio que cae, frente de un paraje que llaman la Ensenada Vieja que esta de la otra banda a la parte del sur, cuya esquina esta distante de las casas y poblasion nueba del dicho encomendero rio abaxo mas de media legua y coxiendo desde dicha esquina a un sauze que esta en ella, hize labrar una cruz en su tronco para que sirva de lindero y desde el rio abaxo se midieron sesen[42r]ta querdas de dichas sinquenta varas que hazen tres mill que pertenesen a la dicha media legua y terminaron sobre dicho rio adonde mande poner un palo por lindero. Y coxiendo desde el rumbo del norte, quarta al nordeste, asia la savana se midieron otras sesenta cuerdas de dichas cinquenta baras que llegaron a la orilla de una cañada que llaman el Estero, adonde hize poner otro palo clavado para que sirva de lindero. $Y$ bolviendo a la dicha esquina y primer lindero de esta medision cojiendo el dicho rumbo del norte, quarta al nordeste a la savana se midieron otras sesenta cuerdas de dichas sinquenta baras que hasen la dicha media legua y terminaron sobre una loma baxa adonde mande clavar otro palo para que sirva de mojon. Con lo cual quedaron medidas y amoxonadas las dichas tierras, de media legua en cuadro y en conformidad de su asignasion las declaro por tierras y redusion de estos dichos indios devajo de los linderos y moxones de suso referidos para que las ayan y tengan por suyas propias y usen de ellas en todo aquello que fuere de su utilidad y convenensia en cumplimiento de leyes y hordenan[42v]sas reales y en su virtud, le di posesion de las dichas tierras a un indio llamado Joseph, por si y en nombre de los demas indios que al presente son y en adelante fueren de esta encomienda la qual dicha posesion le di en nombre de su magestad, real actual corporal [subrayado: iuri domini velquasi] coxiendole de la mano y paseandole por ellas. $Y$ el dicho indio en señal de posesion arranco iervas e hizo otros açtos de posesion y mando a los que presentes estavan se saliesen de dichas tierras y se las 
dejasen libres y desenbarasadas y de como asi tomo la dicha posesion como a las nuebe de la mañana sin contradision de persona alguna me pidio el dicho protetor general se lo diese por testimonio en nombre de sus partes y yo el dicho juez se lo doy en quanto puedo y a lugar de derecho de haver sido y pasado como dicho es, y en su conformidad, mando a todas y qualesquier personas de qualquier estado calidad y condision que sean no sean osados a quitar ni mober los dichos moxones ni inquieten ni perturben a los indios de esta encomienda de [43r] la dicha posesion so las penas dispuestas por derecho y de dossientos pesos aplicados camara de su magestad, en que desde luego les doy por incursos y condenandos lo contrario haciendo. $Y$ en su conformidad mando al dicho capitan Pedro Diez Gomez que dentro de un mes otorgue instrumento publico y autentico ante el escrivano de cavildo de la asignasion de estas dichas tierras devaxo de los linderos de suso referidos para que en todo tiempo conste. $Y$ en cuanto a la capilla mandada hazer en dicha sentensia en atension de no haver tenido pueblo asignado mando al dicho capitan Pedro Diez Gomez que dentro de quatro meses primeros siguientes haga la dicha capilla en las dichas tierras asignadas para que los dichos indios oygan misa los dias de fiesta y sean dotrinados a los tiempos y horas prevenidos por reales hordenansas devajo de las penas contenidas en la hordenanza veinte. Declarando como declaro haver cumplido el dicho encomendero con la paga en que fue condenado por dicha sentensia de los ocho pesos a cada uno de los indios que le an servido y quatro a [43v] las dos indias Antonia y Clara con mas los diez pesos por el castigo que hizo al indio Andrez por haver confesado el dicho protetor general y los demas indios que estavan presentes haverlos rezevido en la dicha ciudad de Cordova de mano de dicho su encomendero al tiempo de la vizita y para que todo tenga cumplido efecto mando a todos los indios e indias muchachos y muchachas de esta encomienda luego se pueblen y asistan y mantengan en estas dichas tierras teniendolas por su redusion sin salir de ellas mas que en los tiempos y cosas prevenidas por leyes y hordenansas reales, y mando asi mismo al dicho encomendero les fomente a ello sin ponerles ningun estorbo ni sacarlos de dicha su redusion cumpliendo en todo con lo que es obligado. Para cuyo cumplimiento les ley y notifique todo lo de suso referido al dicho encomendero y a los dichos indios que lo fueron Joseph, Alonzo, Ignasio, Lorenzo y otro Ignasio en sus personas que dixeron lo oyan y que estan [44r] prontos a cumplir con lo que se les manda cada uno por lo que le toca y que se remita testimonio a dicho señor oydor y vezitador general a costa del dicho encomendero asi, lo probey y firme con el dicho protetor general y encomendero siendo testigos presentes Antonio Piñero Fernando Gutierres y Diego Sentteno que lo firmaron conmigo a falta de escrivano de ello doy fee. Don Manuel de Zevallos Neto y Estrada. Juan Lopez de Fuente Seca. Pedro Diez Gomez. Antonio Piñero. Fernando Guttierrez. Diego Zenteno.

[Al margen: Asignasion de tierras a los indios del sargento mayor Sevastian de Arguello]

En la estansia y paraxe de las Lagunas del sargento mayor Sevastian de Arguello fiel executor y vezino feudetario de la ciudad, de Cordova juridision de ella en siete diaz del mez de diziembre de mill y seisientos y nobenta y tres años. Yo el capitan don Manuel de Zevallos Neto y Estrada alguazil mayor propietario y juez nombrado por el señor doctor don Antonio Martinez Luxan de Vargas del conzejo de su magestad, y su oydor mas antiguo de la real audiensia de La Plata y vezitador [44v] general de esta provinsia del Tucuman por expesial comision del Rey nuestro señor para la execusion y cumplimiento de las sentensias dadas contra los encomenderos de esta juridision. Y por lo que toca a la pronunsiada contra el dicho sargento mayor Sevastian de Arguello en dicha ciudad de Cordova en veinte diaz del mes de abril de este presente año de seisientos y nobenta y tres vine a esta dicha estanzia con asistensia del capitan Juan Lopez de Fuente Seca rexidor y protetor general de los naturales y haviendo hallado [entrelíneas: en ella] a dicho encomendero le ley e hize notoria la comision a mi dada por dicho señor oydor y vizitador general y en su obedesimiento hizo señalamiento de tierras a los indios de su encomienda que tiene desnaturalisados del Valle de Calchaqui, en un arroyo [entrelíneas: que naze de dicho 
parage de las lagunas y corre] en un arroyo abaxo por las casas y poblasion del dicho encomendero las quales reconosidas por mi y dicho protetor general, las hallamos ser comodas y sufisientes para los aprovechamientos de dichos indios por tenerlas con el agua sufisiente y aseguradas estando poblados en ellas dichos indios con sus ranchos y chacras que tienen sembradas de trigo maiz y otras legumbrez que vimos y en su conformidad, mando que se les midan [45r] y amoxonen un quarto de legua en quadro en atension de ser dos indios rezervados y un muchacho ausente llamado Pasqual y otros dos muchachos que se hallan al presente en esta redusion y para su cumplimiento mande medir un cordel de cañamo de sinquenta varas presentes las parttes y coxiendo por el lindero el pie de una loma vaxa que esta como tres quadras poco mas o menos de la junta de dos manantiales que nazen aroyo arriba de dicha loma y cojiendo frente de ella, y orilla del dicho arroyo por el rumbo del sueste, hize medir quinze querdas de dichas çinquenta baras que terminaron sobre una loma alta adonde hize poner un monton de piedras para que sirva de lindero. Y desde el, coxiendo, el rumbo del sueste, al nordeste se midieron treinta cuerdas de dichas çinquenta varas que asen mill y quinientas que son las que tocan a dicho quarto de legua que llegaron sobre una loma enfrentte de un tala y pencal silvestre adonde hize poner otro moxon de piedras para que sirva de lindero. Y cojiendo desde el rumbo del sueste, al nurueste, hize medir otras treinta querdas de dichas cinquenta baras [45v] que llegaron sobre una loma adonde mande hazer otro monton de piedras para que sirva de lindero. $Y$ bolviendo al dicho arroyo y primer lindero de esta medision cojiendo el rumbo del sueste al nordeste hize medir quinze querdas de dichas çinquenta varas que con las otras quinse enteradas a la parte del sueste hazen el dicho quarto de legua adonde mande poner otro monton de piedras quedando conprehendido el dicho arroyo por una y otra parte por las tierras de esta medision. Con lo qual quedaron medidas y amoxonadas el dicho quarto de legua en quadro y en conformidad, de su asignasion las declaro por tierras y redusion de estos dichos indios devaxo de los linderos de suso referidos para que las ayan y tengan por suyas propias y usen de ellas en todo aquello que fuere de su utilidad, y conbeniensia en cumplimiento de leyes y hordenansas reales. Y en su virtud le di posesion de las dichas tierras a un indio llamado Andrez de esta encomienda por si, y en nonbre de los demas indios que al presente son y en adelante fueren de esta dicha encomienda la qu[46r]al se la di, en nombre de su magestad, real actual corporal [subrayado: iure domini velquasi], en forma y segun derecho coxiendole de la mano y paseandole por ellas. Y el dicho indio en señal de posesion aranco iervas y mando a los que presentes estavan se saliesen de dichas tierras y se las dexasen librez y desenbarasadas y de como asi, tomo la dicha posesion como a las onze del dia sin contradision de persona alguna me pidio el dicho protetor general se lo diese por testimonio en nombre de sus partes. Y yo el dicho juez se lo doy en quanto puedo y a lugar de derecho de haver sido y pasado como dicho es, en presensia de dicho encomendero y de los testigos de iuso escriptos y en su conformidad, mando, a todas y qualesquier personas de qualquier estado calidad y condision que sean no sean osados a quitar ni mober los dichos moxonez ni inquieten ni perturben a los indios de esta encomienda que al presente son y en adelante fueren de la dicha posesion so las penas dispuestas por derecho y de dos sientos pesos aplicados camara [46v] de su magestad, en que desde luego les doi por incursos y condenados lo contrario haciendo. $Y$ en su conformidad, mando al dicho sargento mayor Sevastian de Arguello otorgue instrumento publico y autentico ante el escrivano de cavildo, de la asignasion de estas dichas tierras devajo de los linderos de suso referidos para que en todos tiempos conste expresando en dicho instrumento que caen estas dichas tierras veinte y quatro leguaz poco mas o menos de dicha ciudad, de Cordova. $Y$ en quanto a la capilla mandada hazer en dicha sentensia, en atension de no haver tenido pueblo asignado mando al dicho sargento mayor Sevastian de Arguello que dentro de seis meses primeros siguientes, cumpla con la hordenanza veinte, haziendo la dicha capilla para que oygan missas devajo de las penas contenidas en dicha hordenanza. Declarando como declaro haver cumplido el dicho encomendero con la paga de los tres pesos en que fue condenado a cada uno de dichos indios y dos [47r] pesos a las dos indiaz que 
le an servido por haver confesado el dicho protetor general y los dichos indios e indiaz que estavan presentes haverlos rezevido en la dicha ciudad, de Cordova al tiempo de la vezita de mano de dicho su encomendero. Y para que todo tenga cumplido efecto mando a todos los indios e indias muchachos y muchachas de esta encomienda se mantengan y asistan en estas dichas tierras gosando de su livertad sin salir de ellas mas que en los tiempos y cosas prevenidas por leies y hordenanzas reales. Y mando asi mismo al dicho encomendero les fomente a ello sin ponerles ningun estorbo ni impedimento cunpliendo en todo con lo que es, obligado. Todo lo qual les lei y notifique, al dicho encomendero e indios que lo fueron el dicho Andrez y Luis y dichos muchachos llamados Lorenzo y Miguel en sus personas que dixeron lo oyan y que estan prontos a cumplir con lo que se les manda cada uno por lo que les toca y remitase testimonio a dicho señor oydor y vezitador general a costa de dicho encomendero. [47v] Para que le coste, asi lo provey y firme con el dicho protetor y encomendero y testigos que lo fueron presentes el sargento Pedro Fredez de Acosta y don Jorxe Sapata a falta de escrivano de ello doy fee. Don Manuel de Zevallos Neto y Estrada. Juan Lopez de Fuente Seca. Sebastian de Arguello. Testigo Pedro Fredez de Acosta. Don Jorge Zapata.

[Al margen: Asignasion de tierras a los indios calchaquiez de la encomienda del capitan don Sevastian de Carranza y Luna]

En el valle de Calamuchita y estansia que fue del sargento mayor Sebastian de Arguello jurisdision de la ciudad de Cordova veinte leguaz de ella poco mas o menos, en diez diaz de el mes de diziembre de mill y seisientos y noventa y tres años yo el capitan don Manuel de Zevallos Neto y Estrada alguazil mayor propietario y juez nombrado por el señor doctor don Antonio Martinez Luxan de Vargas del consexo de su magestad y su oydor mas antiguo de la real audiensia de La Plata visitador general de esta provincia de Tucuman por expesial comision de su magestad, para la execusion de las sentensias dadas contra los encomenderos de esta juridision y por lo que toca a la proveyda contra el [48r] capitan don Sebastian de Carran [sic] y Luna, en la dicha ciudad de Cordova en quatro dias del mes de abril de este presente año de nobenta y tres que le fue notificada abiendole leido y hecho notoria la comision a mi dada por dicho señor oydor y vizitador general y en su obedesimiento hizo señalamiento de tierras a los indios de su encomienda que tiene, de los desnaturalisados del Valle de Calchaqui, en esta dicha estansia a la qual vine con asistencia del capitan Juan Lopez de Fuente Seca, rexidor y protetor general de los naturales y de los testigos de iusso, escriptos y con los indios de esta encomienda y aviendolas reconosido, las hallamos ser comodas y sufisientes para sus aprovechamientos y con el agua nesesaria por caer sobre el rio Terzero y en conformidad de su asignasion en atension de ser los indios tributarios sinco con mas dos rezervados mando que se les midan y amoxonen media legua en quadro para cuyo cumplimiento hize medir un cordel de cañamo de çinquenta baras [48v] presentes las partes y coxiendo desde la orilla del dicho rio Terzero que cae a la parte del sur, enfrente de una barranca colorada que esta de la otra vanda del dicho rio en deresera de la punta de un serro alto que en lengua de los naturales se llama Rumi Paya y coxiendo por el rumbo del nordeste al sueste, hize medir sesenta querdas de dichas sinquentta varas que hazen tres mill que son las que pertenesen a la dicha media legua de tierras, que terminaron en una cañada angosta adonde hize poner un moxon de piedras para que sirva de lindero. $Y$ desde el coxiendo el rumbo del sudueste al nordeste se midieron otras sesenta cuerdas de dichas sincuenta varas que terminaron sobre una cañada que esta en un paraxe que llaman la Boca de Cantamea, adonde hize poner otro moxon de piedras para que sirva de lindero. $Y$ desde el corriendo el rumbo del sueste al norueste, hasta la orilla del dicho rio Terzero que le haze frente y queda por lindero a la parte del dicho rio abajo, del primero de esta medision quedando conprehendidos [49r] en ella, las casas de tapia y corrales de piedra con toda la cañada en que solia sembrar el dicho sargento mayor Sebastian de Arguello. con lo qual quedaron medidas y amoxonadas estas dichas tierras de la dicha media legua en quadro y en conformidad de su asignasion las declaro por tierras y 
redusion de estos dichos indios devaxo de los linderos de suso referidos para que las ayan y tengan por suyas propias y usen de ellas en todo aquello que fuere de su utilidad, y conbeniensia en cumplimiento de leies y hordenanzas reales. $Y$ en [entrelíneas: su] virtud le di posesion de las dichas tierras a un indio de esta encomienda llamado Francisco Liquimay por si y en nombre de los demas indios que al presente son y adelante fueren de esta dicha encomienda la qual se la di en nombre de su magestad, real actual corporal [subrayado: iuri domini velquasi], en forma y segun derecho coxiendole de la mano y paseandole por ellas y el dicho indio en señal de posesion arranco iervas y mando a los que presentes estavan se saliesen de dichas tierras y se las dexasen librez y desenbara[49v]zadas y de como asi tomo la dicha posesion como a las doze del dia sin contradision de persona alguna me pidio el dicho protetor general se lo diese por testimonio en nombre de sus partes. $Y$ yo el dicho juez se lo doy en quanto puedo y a lugar de derecho de haver sido y pasado como dicho es, en presensia de las dichas partes y del reverendo padre fray Diego Zeliz, del Horden de Predicadores y Lorenzo Alfolso Mexia vezino feudetario quienes se hallaron presentes, como sircunbezinos a estas dichas tierras y en su conformidad, mando a todas y qualesquier personas de qualquier estado calidad y condision que sean no sean osados a quitar ni mober los dichos moxonez ni inquieten ni pertuben a los indios de esta encomienda que al presente son y adelante fueren de la dicha posesion so las penas dispuestas por derecho de dos sientos pesos aplicados camara de su magestad, en que desde luego les doy por incursos y condenados lo contrario haciendo. $Y$ en su virtud, mando al dicho capitan don Se[50r]bastian de Carranza y Luna que deento [sic] de veinte diaz otorgue instrumento publico y autentico ante el escrivano de cavildo de la asignasion de estas dichas tierras para que en todos tienpos conste. $Y$ en quanto a la capilla mandada hazer en dicha sentensia en atension de no haver tenido pueblo asignado mando a dicho encomendero que dentro de seis meses primeros siguientes, haga la dicha capilla dentro de las tierras de esta asignasion para que los indios oygan misa y sean dotrinados a los tiempos y horas prevenidos por reales hordenansas devaxo de las penas y apersevimientos contenidos en la hordenanza veinte en casso de su omision. Y para que [entrelíneas: en] todo tenga cunplido efecto mando a todos los indios e indiaz muchachos y muchachas de esta encomienda luego se pueblen y asistan en estas dichas tierras teniendolas por su redusion sin salir de ellas mas que en los tiempos y cosas prevenidas por leies y hordenanzas reales y mando al dicho encomendero los fomente a ello sin ponerles algun estorbo ni sacarlos de dicha su redusion [50v] cumpliendo en todo con lo que es obligado. Para cuyo cumplimiento les lei y notifique todo lo de suso referido al dicho encomendero e indios de esta encomienda en sus personas que dixeron lo oyan y que estan prontos a cumplir con lo que se les manda cada uno por lo que les toca. Declarando como declaro haver cunplido el dicho encomendero con la paga de los sinco pesos en que fue condenado diese a cada uno de los indios e indias que an estado en su servisio en atension de aver [entrelíneas: confesado] los dichos indios e indias delante de mi dicho juez y protetor averlos rezevido de mano de su encomendero al tiempo de la vizita y despachese testimonio a costa del dicho encomendero para que conste a dicho señor oydor y vizitador general assi lo provey y firme yo dicho juez con el dicho protetor general y encomendero por ante mi y testigos a falta de escrivano siendolo presentes a todo lo referido el sargento mayor Sebastian de Arguello fiel executor y don Jorxe de Zapata de ello doi fee. Don Manuel de Zeballos Neto y Estrada. Juan Lopez de Fuente Seca. Don Sevastian de Carranza y Luna. Sevastian de Arguello. Don Jorxe Zapatta.

[Al margen: Autto]

En el Valle de Calamuchita y estansia del capitan Juan Clemente de Vaygorre jurisdision de la çiudad, de Cordova quinze leguaz de ella poco mas o menos en doze diaz del mez de diziembre de mill y seisientos y nobenta y tres años. Yo el capitan don Manuel de Zevallos Neto y Estrada alguazil mayor y juez nombrado por el señor doctor don Antonio Luxan de Vargas del consexo de su magestad, y su oydor mas antiguo de la real audiensia de la çiudad de La Plata vizitador 
general de esta provinsia de Tucuman por expesial comision del Rey nuestro señor para la execusion de las sentensias dadas por dicho señor vizitador general a los vezinos de esta juridision y por lo que toca a la pronunziada contra el dicho capitan Juan Clemente de Vaigorre en dicha çiudad de Cordova en dos diaz del mez de abril de este presente año de nobenta [51v] y tres, mando se le notifique al susodicho que dentro de seis diaz primeros siguientes redusga al pueblo de Nongolma todos los indios e indias muchachos y muchachas de su encomienda segun se manda en dicha sentensia lo qual cumpla pena de çinquenta pesos aplicados camara de su magestad, y por lo que toca a la capilla y pagas mandadas hazer a los indios e indias que an estado en su servisio reserbo a vista de ojos y presentes las partes proveer lo demas que conbenga con apersevimiento que dicho termino pasado se dara el remedio conbiniente en horden a su execusion asi, lo provey mande y firme por ante mi y testigos a falta de escribano. Don Manuel de Zevallos Neto y Estrada. Testigo Juan Lopez de Fuente Seca. Testigo Pedro Fredez de Acosta.

[Al margen: Notificacion]

En el Valle de Calamuchita y estansia de el capitan Juan Clemente en catorze dias del mez de diziembre de mil y seisientos y nobenta y tres años yo el dicho juez lei y notifique el auto de suso por mi proveydo al [52r] capitan Juan Clemente de Vaigorri en su persona que lo oyo y aviendolo entendido dijo que en su poder y hazienda de Calamuchita no tiene ningun indio de sus encomendados por haverse desparramado, desde el tiempo de la vizitta y que solo save, estan en la toma de la çiudad de Cordova Domingo con su muger llamada Micaila sin hijos. Cristobal con su muger Izabel, sin hijos. Andrez casado con Maria con tres hijos Juan, Bernabela y Maria. Diego casado con Barbola con dos hijos llamada la una Maria y otro de pechos que no save su nombre. Antonio con su muger e hijos que estan en Panaolma estansia de el capitan don Bartolome de Olmedo. Bernabe casado con Theresa y tiene dos hijas llamadas Luiza y Dominga que estan en la estansia de San Agustin de los padres de Santo Domingo. Antonio Paraguai y agregado a dicha encomienda casado con Phelipa y tienen por hijos a Lucas, Pasqual, Antonio y Cristobal. Miguel casado con Juana tiene por hijos a Matheo y a Francisco y Maria. Juan guerfano hijo de Alonso difunto. Geronimo guerfano. Pasqual guerfano hijo de Lorenzo. Izabel viuda de Gregorio con una [entrelíneas: hija] llamada Maria soltera. Bernabela [52v] hija de Maria soltera. Juana soltera. Josefa soltera. $Y$ ausentes se hallan otras familias en las ciudades de esta provincia todos los quales esta pronto a redusirlos a su pueblo de Nongolma dandosele horden judisial para ello con el tienpo conpetente sobre que protesta pedirlo en forma. $Y$ en quanto a las pagas de los diez pesos mandadas pagar a los indios e indias que le an servido dijo las tiene fechas ante su protetor al tiempo de la vizita como lo declararan en estando en su redusion presentes. Lo qual visto por mi dicho juez reservo con vista de la petision de dicho encomendero el dar la comision que fuere nesesaria para que sean redusidos los dichos indios al dicho pueblo de Nongolma y para que conste lo pongo por diligensia y lo firme con dicho encomendero y testigos a falta de escribano. Don Manuel de Zevallos Neto y Estrada. Juan Clemente de Vaigorri. Testigo Juan Lopez de Fuente Seca. Testigo Miguel de Brizuela.

[Al margen: Exsortatorio]

El capitan don Manuel de Zevallos Neto y Estrada alguazil mayor propietario de la ciudad de Cordova y juez nombrado por el señor doctor don Antonio Martinez Luxan de Vargas del consexo de su magestad, su oydor mas antiguo de la real audiensia de La Plata [53r] y vezitador general de esta provinsia de el Tucuman, por expesial comision del Rey nuestro señor para la execusion de las sentensias dadas contra los vezinos feudetarios de esta juridision. Hago saver a vuestra merced señor sargento mayor don Antonio Zuares de Cabrera alcalde hordinario de sigundo voto de dicha ciudad de Cordova y por su ausensia a vuestra merced señor maese de campo don Enrrique de Sevallos Neto y Estrada cavallero del Horden de Santiago alferez real de la dicha ciudad, de Cordova o a quien usare el dicho cargo de alcalde hordinario de sigundo voto que en 
cumplimiento de la comision a mi dada por dicho señor oydor y vizitador general que tengo hecha notoria ante el cavildo justisia y reximiento de esa dicha ciudad me hallo con asistensia del capitan Juan Lopez de Fuente Seca rexidor y protetor general de los naturales en esta estansia llamada el Sauze hazienda que es de don Francisco de Texeda menor e hijo lixitimo de el maese de campo don Francisco de Texeda vezino feudetario que fue en primera vida en cuyo feudo a susedido por fin y muerte del dicho su [53v] padre para la asignasion de tierras sufizisientes con el agua nesesaria que se a de hazer a los indios de su encomienda en conformidad de la obligasion que contraxo dicho encomendero en que fue gravado por el dicho señor oydor y vizitador general por la sentensia que en esta razon se sirvio de probeer que sacada a la letra es del tenor siguiente.

[Al margen: Sentencia]

En la causa de visita de la encomienda de don Francisco de Texeda vistos los autos cargos hechos con lo que serca dellos a pedido el protetor de los naturales y alegasion del dicho encomendero y lo demas dedusido, fallo atento a los autos y meritos de esta causa probanza fecha de que rezultan los cargos y declarasion del administrador de la encomienda en su conprobasion que le devo de condenar y condeno en sien pesos de a ocho reales aplicados a la camara de su magestad, y en las costas de esta causa y que satisfaga a la india Maria por razon de los asotes diez pesos de a ocho [54r] reales y por lo que toca a los asotes del indio Andres en el rollo absuelvo de dicho cargo a dicho administrador y reservo el derecho al protetor para que pida contra el juez, o alcalde que los mando dar, si no ubiere avido justificasion de causa lo que conbenga al de el indio en el juisio de la rezidensia. Y por lo que toca al interez de los indios mando que respeto de la claridad, de la quenta de cargo y data de la paga, de los jornales de los indios se ajuste y liquide en mi presensia con asistensias de las partes y del protetor general para que de su ajuste rezulte el alcanse liquido. Y por no haverse asignado el estipendio fixo que conforme a la lei, se devio poner se le [sic] y pague por el tiempo atrasado a los indios que an servido a diez pesos de a ocho reales a cada uno y seis a las indias ezepto al idio [sic] Joseph a quien reservo el derecho para que breve y sumariamente se aberigue la falta de servisio y paga de tributo que alega el administrador. $\mathrm{Y}$ asimismo mando en conformidad de lo pedido por el dicho protetor general [54v] en su escripto de cargos que dentro de ocho dias haga asignasion de tierras sufisientes con el agua nesesaria con asistensia del protetor y justisia hordinaria o persona que yo nombrare en conformidad, de la obligasion que contraxo quando entro en la posesion de dicha encomienda por haverse dado esta, con este grabamen al padre de dicho encomendero como se expresa en su titulo que devio executarse luego que se tomo la posesion asi por el uno como por el otro en sus tiempos y se executara lo referido a costa de dicho encomendero y en instrumento publico y autentico para que en todo tiempo conste. Y asi mismo hara capilla para que los indios oygan missa los dias de fiesta cuydando como es de su obligasion de la doctrina cristiana porque el motivo y origen de las encomiendas fue el bien espiritual y temporal de los indios y su doctrina y enseñanza en los articulos y preseptos de nuestra santa fee catholica cumpliendo con la hordenanza veinte con los apersevimientos y penas contte[55r]nidas en ella. Y en lo de adelante no se servira de las indias de dicha encomienda sola pena de la ley que lo proibe guardando en todo lo demas las leies y hordenanzas hechas por el señor don Francisco de Alfaro oydor de la real audiensia de La Plata vizitador que fue de esta provinsia por haverse desnaturalizado estos indios y los demas calchaquies devajo del siguro de dichas hordenanzas que igualmente prohiben el servisio personal para que los indios gosen de su livertad como la gosara en la dicha redusion el indio nombrado Salvador cuya pretension declaro no haver lugar atendiendo a la antiguedad de ella, y posesion que a tenido el encomendero y su antesesor desde el año de sesenta y sesenta y ocho y solo podra ocurrir el protetor general por lo que toca a este derecho a la real audiensia de La Plata si le conviniere. Y se advierte y apersive a dicho administrador el buen tratamiento que debe ha[55v]zer a sus encomendados sin tener facultad para castigarlos por su persona pena de 
mil pesos y que si se exsediere en el castigo se exsedera tambien en la pena cuydando de que ni la muger del dicho administrador ni el mayordomo ni otras personas los castiguen ni maltraten porque quedara obligado en estos casos el encomendero como si el lo executara y asi lo provey mande y firme con costas. Don Antonio Martinez Luxan. Pronunsio esta sentensia el señor doctor don Antonio Martinez Luxan de Vargas del consexo de su magestad, su oydor mas antiguo de la real audiensia de la ciudad de La Plata y vizitador general de esta provinçia del Tucuman por expesial comision del Rey nuestro señor en los estrados de su audiensia siendo testigos el capitan don Fernando de Ulloa y Tavera y Cristobal de Heredia en esta ciudad de Cordova en diez de abril de mill y seisientos y nobenta y tres años. Ante mi. Lorenso Pinto escrivano reseptor.

[Al margen: Notificacion]

En el dicho dia lei y notifiqique la sentensia de la foxa antesedente al sargento mayor don Fadrique Alvarez [56r] de Toledo administrador de dicha encomienda quien dijo lo oya de que doy fee Lorenzo Pinto escrivano reseptor.

[Al margen: Notificacion]

En el dicho dia lei y notifique la sentensia de suso al capitan Juan Lopez de Fuente Seca protetor general de esta dicha çiudad quien dijo lo oya, de que doy fee. Lorenzo Pinto escrivano reseptor. [Al margen: Prosigue] Para cuya execusion y cunplimiento en atension de que es llegado a mi notisia es, muerto el general don Antonio de Godoy aguelo lexitimo y tutor y curador de la persona y vienes del dicho don Francisco de Texeda menor y no haver hallado persona que por su parte se pueda hazer este juisio asi, para la asignasion de tierras que se a de hazer segun el numero de los indios de esta encomienda y se haga la capilla que es obligado dentro de los seis meses asignados por dicho señor vizitador general y para que se otorgue el instrumento publico y autentico de dicha asignasion de tierras y lo demas contenido en dicha sentensia. De parte de su magestad, Dios le guarde, y de la dicha comision que exerso exsorto y requiero a vuestra merced, señor alcalde de segundo voto y de la mia pido y suplico se sirba, luego que le conste de este mi [56v] auto, exsortatorio, mandar notificar al tutor administrador, que fuere de la persona y vienes del dicho don Franssisco de Texeda menor paresca antte mi en esta dicha estansia del Sauze para hazer la dicha asignasion de tierras, y cumplir de parte de dicho menor con todo lo demas contenido [tachado: contenido] en dicha sentensia de suso inserta. $Y$ en caso de no haverlo nombrado se sirva vuestra merced, de dar la providensia que convenga, nombrando [entrelíneas: persona] con quien se pueda hazer este juicio en nombre de dicho menor con apersevimiento que de no hazerse; pasare, a hazer la dicha asignasion de tierras a los dichos indios de esta encomienda en las de esta, estansia del Sause, por el derecho que en ellas tienen adquirido en la cantidad, que les pertenesiere segun el numero de ellos y devajo de gravamen de dicha su obligasion y que correran por quenta de dicho menor los diaz y salarios que se recresieren a mi dicho juez y protetor general en la demora que ubiere, que al tanto hare, cada que las de vuestra merced vea, justisia mediante y mando al sargento mayor Thomas de Salas escrivano de su magestad asi, lo haga saver a dicho señor alcalde de segun[57r]do voto poniendolo por diligensia $\mathrm{y}$ fecho se me remita orijinal con lo en su virtud obrado para que conste, que es fecho en esta dicha estansia del Sauze juridision de la ciudad, de Cordova doze leguas de ella poco mas o menos en doze diaz del mes de diziembre de mil y seisientos nobenta y tres años por ante mi y testigos a falta de escribano. Don Manuel de Zevallos Neto y Estrada. Testigo. Juan Lopez de Fuente Seca. Testigo. Clemente de Otañez.

[Al margen: Diligencia]

En la ciudad de Cordova en catorze diaz del mes de diziembre de mil y seisientos y nobenta y tres años yo el presente escrivano de su magestad, hize saver el exsortatorio remitido por el capitan don Manuel de Zevallos alguazil mayor y juez de comision nombrado por el señor oydor y 
vizitador general al maese de campo don Enrique de Zevallos del Horden de Santiago alferez real que exerse la vara de alcalde hordinario por ausensia del sargento mayor don Antonio Suarez de Cabrera que lo es propiettario y aviendo visto su merced dicho exsortatorio dijo su merced [57v] que atento a que la dicha sentensia habla con el administrador de los vienes de don Francisco de Texeda menor sargento mayor don Fadrique Alvarez de Toledo se le notifique al suso dicho lo contenido en dicho exsortatorio para que como tal administrador cumpla con su tenor devajo de los apersevimientos en el contenidos y lo firmo don Enrrique de Zevallos Neto Estrada. Ante mi. Thomas de Salas escrivano de su magestad.

[Al margen: Auto]

En la dicha ciudad, en el dicho dia catorze de diziembre, de dicho año notifique el auto de suso al sargento mayor don Fadrique Alvarez de Toledo administrador de don Francisco de Texeda menor en su persona que lo oyo el qual dijo que al presente se halla en negosios del servisio de su magestad, que presisamente piden su asistensia por las quales dichas razones se halla escusado para poder asistir en persona al señalamiento de las tierras que se le an de señalar a los indios de la encomienda de dicho menor y que su merced de dicho señor alcalde [58r] nombre la persona que fuere servido para que asista en nombre de dicho menor a dicho señalamiento [entrelíneas: por dicho administrador y estando presente dicho señor alcalde dijo que en birtud de lo respondido haze nombramiento] de tal defensor de dicho menor en la persona del capitan don Luis Granados deudo de dicho menor, para que en su nombre, asista a dicho señalamiento de tierras mirando por parte de dicho menor no sea dagnificado en dicho señalamiento y caso que ayga algun inconbiniente de ausensia o, otro justo impedimento el capitan don Manuel de Zevallos juez de dicha comision nombre la persona que le paresiere para que asista a dicha diligensia y [entrelíneas: se] cumpla con lo que dicho señor vizitador general manda y lo firmaron. Don Enrrique de Zevallos Neto Estrada. Don Fadrique Alvarez de Toledo. Ante mi. Thomas de Salas escrivano de su magestad.

[Al margen: Nombramiento de persona]

En el Valle de Calamuchita juridision de la ciudad de Cordova en quinze diaz del mes de diziembre de mill y seisientos y nobenta y tres años yo el dicho alguazil mayor y juez de comision aviendo vis[58v]to lo proveydo por el maese de canpo don Enrrique de Zevallos Neto y Estrada cavallero del Horden de Santiago alferez real que exerse la vara de alcalde hordinario de segundo voto de la dicha ciudad de Cordova al exsortatorio por mi fecho sobre que se nombrase persona que asistiese a la asignasion de tierras que se an de dar a los indios de la encomienda de don Francisco de Texeda menor en que pareze se nombra en la persona del capitan don Luis Fernandez Granado quien parese se halla ausente y se a ido a la dicha çiudad de Cordova y atendiendo a que se me da facultad, por dicho alcalde hordinario con asistensia del sargento mayor don Fadrique Alvarez de Toledo administrador de dicho menor para nombrar persona que asista a dicha diligensia atendiendo a la integridad y zelo de la persona del capitan Juan Clemente de Vaigorri, hago el dicho nombramiento en su persona para que asista de parte de dicho menor a la dicha asignasion de tierras que se [59r] an de dar a los dichos indios en la estansia del Sauze, que fue del maese de campo don Francisco de Texeda primer encomendero de estos indios por el derecho que en ellas tienen adquirido y haverlas estado poseyendo. A quien estando presente le hize saver el dicho nombramiento y aviendolo asetado juro por Dios nuestro señor y una señal de cruz que selebro segun forma de derecho de usar vien y fielmente el dicho nonbramiento y en su conformidad mando se haga vista de oxos de dichas tierras y fecho con asistensia del suso dicho y el protetor general se haga la dicha asignasion de tierras en la parte que fuere conbiniente para la utilidad de dichos indios y para que conste lo firme con la parte y testigos a falta de escribano. Don Manuel de Zevallos Neto y Estrada. Juan Clemente de Vaygorri. Testigo. Juan Lopez de Fuente Seca. Testigo Clemente de Otañez. 
[Al margen: Asignacion de tierras a los indios de don Francisco de Texeda menor]

En la estansia del Sauze de don Francisco de Texeda menor juridision de la ciu[59v]dad, de Cordova treze leguas de ella poco mas o menos en diez y seis diaz del mes de diziembre de mil y seisientos y nobenta y tres años yo el capitan don Manuel de Zevallos Neto y Estrada alguazil mayor propietario y juez nombrado por el señor doctor don Antonio Martinez Luxan de Vargaz del consejo de su magestad su oydor mas antiguo de la real audiensia de la ciudad de La Plata y vizitador general de esta provinsia del Tucuman por expezial comision del Rey nuestro señor para la execusion de las sentensias dadas a los vezinos encomenderos de esta juridision y por lo que toca a la proveyda contra don Francisco de Texeda menor su fecha en dicha ciudad de Cordova en diez de abril de este presente año de nobenta y tres y en cunplimiento de el auto por mi proveydo ayer quinze del corriente hize reconosimiento y vista de ojos de un paraxe de dicha estansia del Sauze que esta arroyo avajo de las [tachado: Sauze] casas y guerta del dicho encomendero que en atension de hallarze poblados y en ellas los indios de esta enco[60r]mienda hizo asignasion de ellas el capitan Juan Clemente de Ivaigorri en nombre de dicho menor como persona nombrada para este efecto y aviendolas reconosido con asistensia del capitan Juan Lopez de Fuente Seca rexidor y protetor general de los naturales y hallando dichas tierras ser frutiferaz y con el agua sufisiente para sus granxerias teniendolas sembradas dichos indios y en su conformidad, mando que se les midan y amoxonen tres cuartos de legua y sinco querdas mas de sinquenta baras cada una desde la sierra vaja que corre de asia la parte de Cordova asia la sierra grande que llaman de Yacanto por el rumbo del sudueste y media partida a lo este [al oeste?] para que queden conprehendidas el otro arroyo que vaxa de la cañada que llaman de la Calle, y de norte a sur, de ancho veinte sinco querdas de dichas sinquenta varas en atension de ser seis los indios de esta encomienda y serles en su mayor utilidad y por quedar mas distantes de las casas de su encomendero [60v] en cuya atension hize medir un cordel de cañamo de sinquenta baras y coxiendo por lindero el pie de la dicha sierra vaxa y por el dicho runbo de la media partida del sudueste, a lo este [al oeste?], y por sobre los moxones que dividen las tierras del capitan don Sevastian de Carranza y las de el dicho menor hize medir nobenta y sinco querdas de dichas sinquenta varas que hazen quatro mil setesientas y sinquenta baras que son las que pertenesen a los dichos tres quarto, de legua y sinco querdas de suso referidas que terminaron junto a unos peñascos grandes pasado el dicho arroyo que llaman de la cañada de la Calle adonde hize poner un monton de piedras para que sirviese de lindero. Y coxiendo desde el runbo de sur a norte hize medir las dichas veinti y sinco querdas que hazen un mill dusientas y sinquentta baras por cuyo rumbo se encontro con otro aroyo que vaja de asia la parte del poniente y entra en el dicho que llaman de la [61r] cañada de la Calle, las quales terminaron sobre este, de la otra parte y de la vanda del norte adonde hize poner otro monton de piedras para que sirva de lindero. Y aviendo buelto al pie de la dicha sierra vaja, y primer lindero de esta midision coxiendo el rumbo de sur a norte hize medir otras veinte y sinco querdas de dichas sinquenta varas que terminaron al pie de la dicha sierra vaja junto a un arbol de espinillo adonde hize poner otro monton de piedras para que sirva de lindero. Con lo qual quedaron medidas y amoxonadas las dichas tierras de dos leguas en sircumferensia que son las que les corresponden a media legua en quadro y en conformidad de su asignasion las declaro por tierras y redusion de estos indios devajo de los linderos [entrelíneas: de suso] referidos para que las ayan y tengan por suyas propias y usen de ellas en todo aquello que fuere de su utilidad, y conbenienzia en cumplimiento de leyes y hodenanzas reales. $Y$ en su virtud le di posesion de las dichas tierras a un indio llamado Salvador [61v] de esta encomienda por si, y en nonbre de los demas indios de ella que al presente son y adelante fueren la qual se la di en nombre de su magestad actual corporal iure domini vel quasi en forma y segun derecho, coxiendole de la mano y paseandole por ellas, y el dicho indio en señal de posesion arranco iervas y mando a los sircustantes se saliesen de ellas y se las dexasen libres y desenbarasadas y de como asi tomo, la dicha posesion entre las tres y quatro oras de la tarde sin contradision de persona 
alguna me pidio el dicho protetor general se lo diese por testimonio en nombre de sus partes e yo el dicho juez se lo doy en quanto puedo y a lugar de derecho de haver sido y pasado como dicho es, y en su conformidad, mando a todas y qualesquier personas de qualquier estado calidad y condision que sean no sean osados a quitar ni mober los dichos moxonez ni inquieten ni [62r] perturben a los indios de esta encomienda de la dicha posesion so las penas dispuestas por derecho y de dusientos pesos aplicados camara de su magestad en que desde luego les doy por incursos y condenados lo contrario haciendo. $Y$ en su conformidad, mando se le notifique al sargento mayor don Fadrique Alvarez de Toledo o a la persona que fuere su tutor otorgue instrumento publico y autentico en nombre de dicho encomendero ante el escrivano de cavildo dentro de diez diaz de la asignasion de estas dichas tierras devajo de los linderos de suso referidos para que en todos tiempos conste. Y quanto a la capilla mandada hazer en atension de no haver tenido tierras asignadas estos indios mando assi mismo se le notifique al dicho administrador que dentro de seis meses primeros siguientes haga la dicha capilla dentro de las tierras de esta asignasion para que los dichos indios oygan misa y sean doctrinados a los tiempos $\mathrm{y}$ horas prevenidos por reales hordenanzas devajo de las [62v] penas y apersevimientos contenidos en la hordenanza veinte, de esta provinsia declarando como declaro haver cumplido el dicho administrador con la paga de los diez pesos y seis a las indias que an servido por aber confesado en mi presensia haverseles pagado al tiempo de la vizita y ajustadose de quentas con asistensia del dicho protetor general quien dijo haver sido asi. Y para que todo tenga cumplido efecto mando a todos los indios e indiaz muchachos y muchachas de esta encomienda las mantengan y asistan en ellas gosando de su livertad sin salir de dichas tierras mas que en los tiempos y cosas prevenidos por leyes y hordenanzas reales. Y mando asi mismo se le notifique al dicho administrador les fomente a ello sin ponerles ningun estorbo ni inpedimento cumpliendo en todo con lo que es, obligado en nombre de dicho encomendero menor todo lo qual les ley y notifique a los dichos indios e indias en sus personas que dijeron lo oyan y que estan prestos a cumplir con lo que se les [63r] manda y remitase testimonio a dicho señor oydor y vizitador general a costa del dicho encomendero para que le coste asi lo provey y firme con las dichas partes y testigos que se hallaron presentes a todo lo referido el maestro don Francisco Alvarez de Toledo presvitero los capitanes don Sevastian de Carranza y Luna alcalde de la santa hermandad y Clemente de Otañez a falta de escrivano de ello doy fee. Don Manuel de Zevallos Neto y Estrada. Juan Lopez de Fuente Seca. Juan Clemente de Vaigorri. Maestro Don Francisco de Benegas Toledo. Don Sevastian de Carranza y Luna. Testigo Clemente de Otañez.

[Al margen: Diligencias echas en el pueblo de Guayascate]

En este pueblo de Guaiascatte, juridizion de la ciudad de Cordova, veintte y quatro leguas della poco mas o menos en tres dias del mes de octubre de mill y seissienttos y nobentta y tres años yo, el capitan don Manuel de Zevallos alguasil maior de la dicha ciudad y jues nombrado por el señor doctor don Antonio Martines Luxan de Bargas del consejo de su magestad y su oidor mas anttiguo de la real audiencia de La Platta bissitador general desta probincia [63v] del Tucuman por expesial comission del Rey nuestro señor para la execusion de las sentencias dadas a los besinos feudatarios de esta juridizion y ser comprehendido en la dada por dicho señor vissitador general, el capitan don Leandro Ponze de Leon bezino feudatario de los indios de este dicho pueblo de Guaiascatte en que se sirbio de mandar a dicho encomendero que dentro de seis meses hiziese capilla, y la acavase, poniendola en estado de que se diga missa con desençia, remitiendo a su señoria testimonio de averlo cumplido dentro del dicho termino su fecha la dicha centensia, en la dicha ciudad de Cordova, en ocho del mes de abril de mill y seissientos y nobenta y tres años como mas largamentte consta de dicha centensia a que me remitto haviendo llegado a este dicho pueblo con asisttencia del capitan Juan Lopes de Fuentte Seca, rexidor y protetor general de los naturales haviendo reconossido el estado de dicha capilla hallandose presentte, don Joseph Samaniego curaca, de dicho pueblo y Joseph Labasta con otros dos indios de dicho pueblo 
certifico en quantto puedo y a lugar de derecho que abiendo reconozido el estado de dicha capilla [64r] la alle enpessada, los simienttos de piedra y barro y su altto del suelo de poco mas de una bara y juntto a ella, dos montones de adobes echos y por no estar acavada dicha capilla preguntte, a dicho curaca, e indios la causa, de no aberse acavado y dijeron que despues de la bissita que hiso el señor oidor no se avia puesto mano en ella, porque sus simienttos como parezian los abia hallado dicho señor oydor quando passo por este pueblo en cuia atenzion mando [agregado: con]paresca antte mi el dicho encomendero con los indios deste pueblo para que den razon si estan pagados de los dies pesos que por dicha centtensia manda se les pague a cada uno de dichos indios que le an servido con los beintte pessos mas en que fue condenado por el interes de aver sembradoles sus tierras quienes dijeron estan pagados de todas las dichas condenassiones aviendoseles satisfecho en dicha ciudad de Cordova con assistenzia de dicho protetor quien confesso aver sido asi. Y por lo que toca a no estar acavada la dicha capilla el dicho encomendero de razon por que no a dado su cumplimientto y con lo que dijere se de quentta $[64 \mathrm{v}]$ a dicho señor oydor y bissitador general y por quantto los dichos indios se me an quejado que el dicho encomendero les obliga con rigor a que les sirvan dos muchachos de esta encomienda llamados Pablo hijo de Joseph Labasta y el otro Geronimo mandado assimismo de razon porque lo hase reserbando con lo que dijere probeer lo que contenga assi lo provei mande y firme por ante mi y testigos a falta de escribano. Don Manuel de Zevallos Netto y Estrada. Juan Lopes de Fuentte Seca Migel de Tores.

[Al margen: Declarazion]

Luego incontinenti en dicho dia mes y año ariba dichos y en cumplimientto de lo por mi proveido parezio antte mi dicho jues el capitan don Leandro Ponze de Leon besino feudatario de quien resevi juramentto, por Dios nuestro señor y una señal de cruz que hisso segun forma de derecho $\mathrm{y}$ aviendo jurado prometio de dezir berdad de lo que supiere y fuere preguntado haviendosele leido la fee por mi dada del estado de la capilla que no a dado cumplimientto en el termino de seis meses que le fue asignado por la centençia que el señor oydor y vissitador general, pronunzio, y le esta notificada en ocho del mes de abril passado de este pressentte año cuyo [65r] termino para ser cumplido le faltan solos sinco dias con lo demas que contiene. Dijo que luego que se fue dicho señor oydor caio enfermo y lo estubo beintte dias y que consicutibamentte se hallo su esposa en meses maiores que le pressisaron a su assistençia el qual tiempo dio una lijera a este pueblo y dejo a los indios dies vueyes y una carretta, para que fuesen acarreando la madera, que tiene cortada, poco mas de una legua lo qual no lo an echo y se an perdido los bueyes y se bolbio a la ciudad a dicha asistençia en donde se le estava muriendo una esclava, y se murio al segundo dia de llegado sin tener otra y consecutibo fue Dios servido pariese su mujer y al pressentte se halla aunque enfermo de un brazo por averse quebrado una islilla, dispuesto a acavar dicha capilla. $Y$ en quantto a los dos muchachos que tiene en su servicio dijo que en quantto a Geronimo guerfano de padre y madre lo tiene en su serviçio desde que entro en esta encomienda para que le ensille un cavallo y le de un jarro de agua y lo demas que como criatura puede aser a quien le paga dandole de bestir y de comer y por enseñarle la dotrina cristiana y por lo que toca a Pablo hijo [65v] de Joseph Labasta lo tiene en su servicio desde ayer que llego a este pueblo de su estanzia de los Altos y lo despacho a la ciudad de Cordova a traer unas bacas con otro moso todo lo qual dijo ser la berdad de lo que passa y que esta prontto a pagarle, su travaxo so cargo del juramento que lleva fecho en que se afirmo y ratifico y aviendosele leido su declaraçion dijo estava vien escripta y ser de edad de treinta y dos años poco mas o menos y lo firmo conmigo y testigos a falta de escribano. Don Manuel de Zevallos Netto y Estrada. Don Leandro Ponze de Leon. Testigo Juan Lopes de Fuentte Seca. Testigo Migel de Torres.

[Al margen: Decretto] 
Luego incontinenti aviendo visto la declarazion de susso por lo que toca a los dos muchachos de esta encomienda mando se de traslado al protetor general de los naturales con bista de que reserbo proveer lo que conbenga y lo firme por ante mi y testigos a falta de escribano. Don Manuel de Zevallos Netto y Estrada. Testigo don Pedro de los Rios. Testigo Migel de Torres.

[Al margen: Petticion]

El protetor general de los naturales por la defensa de Geronimo muchacho guerfano hijo de Pedro Labasta y de Isabel india naturales de este pueblo [66r] de Guaiascatte y de Pablo muchacho hijo de Joseph Labasta encomienda del capitan don Leandro Ponze de Leon digo que por vuestra merced se me a dado traslado de la declarazion hecha, por el dicho encomendero y sin embargo de la escusa que da de tener dichos muchachos en su servicio se a de servir vuestra merced de mandar al dicho encomendero que buelva los dichos muchachos a este su pueblo para que assistan en el el uno con dicho su padre y el otro con Ines india desta encomienda por ser tia carnal del dicho muchacho Geronimo quien me a ymformado le a criado y tenido en su poder despues que murio la madre, del susodicho por estar proibido por leies y ordenansas reales que los encomenderos puedan sacar los indios y muchachos de sus encomiendas para servirse de ellos con pretesto ninguno mandando al susodicho luego los buelva a este su pueblo y que cumpla con la centenzia dada en esta razon por el señor oydor vissitador y con la reedificasion de la capilla que se le mando aser por lo qual a vuestra merced pido y suplico provea de justissia en todo segun que pido en que mis partes reziviran merced con justissia la qual pido y lo nesesario etcetera. Juan Lopez de Fuente Seca.

[Al margen: Auto]

En este pueblo de Guaiascate juridicion de la ciudad de Cordova en tres [66v] dias del mes de octubre de mill y seissientos y nobenta y tres años se presentto esta petission por el protetor general de los naturales ante mi el capitan don Manuel de Zevallos aguazil maior y juez nombrado por el señor doctor don Anttonio Martines Luxan de Bargas del consejo de su magestad y su oydor mas antiguo de la real audiencia [entrelíneas: de La Plata visitador general de esta provincia] de Tucuman por espessial comission del Rey nuestro señor por mi bista mando al capitan don Leandro Ponze que dentro de un dia de y entriegue el muchacho Geronimo que tiene en su servicio y estançia reduziendolo a su pueblo y a poder de Ignes india de esta encomienda por ser su tia y por lo que toca a Pablo muchacho hijo de Joseph Labastta en atencion a que por su declarassion que tiene fecha dicho encomendero consta lo despacho a la ciudad de Cordova que dista de este paraje beinte y quatro leguas mando al dicho encomendero que dentro de ocho dias primeros siguientes traiga al dicho muchacho Pablo a su reduzion y pueblo entregandole a Joseph Labasta su padre lo qual cumpla pena de sinquenta pesos aplicados camara de su magestad sin enbargo de qualquiera suplica o respuesta que pretenda dar porque [67r] declaro no aber lugar en cumplimientto de leyes y hordenanssas reales con aperzevimientto que el termino passado no abiendolo cumplido les are parezer y restituir a costa del dicho encomendero y para que en todo tenga cumplido efecto mando se le notifique este decreto assi a dicho encomendero como al protetor general de los naturales para que les conste y por lo que toca a la reedificassion de la capilla a que es obligado dicho encomendero en atension a que no a dado su cumplimientto y faltarle dias para los seis meses de plasso mando se de quentta a dicho señor oydor bissitador general para que con bista de lo obrado probea y mande lo que fuere servido assi lo probei mande y firme por antte mi y testigos a falta de escrivano siendolo presenttes Migel de Torres y el capitan don Pedro de los Rios don Manuel de Zevallos Netto y Estrada. Testigo Don Pedro de los Rios. Testigo Migel de Torres.

[Al margen: Notificacion] 
En el pueblo de Guaiascatte en tres dias del mes de octubre de mill y seissienttos y nobentta y tres años oy el dicho jues lei y notifique el autto de suso por mi probeido a los capitanes don Leandro Ponze de Leon y Juan Lopes de Fuentte Seca protetor general de los naturales en sus personas que lo oye[67v]ron y dijeron que estan prontos a cumplir con lo que cada uno es obligado y para que conste lo firmaron conmigo a falta de escrivano de ello doy fee. Don Manuel de Zevallos Neto y Estrada. Don Leandro Ponse de Leon. Juan Lopes de Fuentte Seca.

[Al margen: Diligenzia]

Certifico en quantto puedo y a lugar de derecho yo el capitan don Manuel de Zevallos Netto y Estrada alguasil maior de la ciudad de Cordova y jues nombrado por el dicho señor oydor y vissitador general de esta probincia que en cumplimiento de lo por mi probeido ayer tres del corriente en el pueblo de Guaiascatte saque testimonio de las sinco foxas anttezedentes escritas en todo y en parte de las dilixencias fechas en razon de la capilla petission del protetor en razon de la restituizion de los dos muchachos que tenia el encomendero con lo por mi probeido para efecto de remitirlo a dicho señor oydor y vissitador general lo qual hise oy quatro del mes de octubre de mill y seissienttos y nobenta y tres años desde este paraje de Baca Coral pueblo de los indios de don Juan Xuares de Cabrera juridicion de la dicha ciudad de Cordova veintte y dos leguas de ella poco mas o menos y para que de ello conste lo firme. Don Manuel de Zevallos Netto y Estrada.

[Al margen: Auto]

En la ciudad de San Phelipe de Lerma Valle de Saltta en veinte y dos [68r] dias del mes de nobiembre de mill y seissientos y nobentta y tres años el señor doctor don Anttonio Martines Luxan de Bargas del consejo de su magestad su oydor mas antiguo de la real audienzia de la ciudad de La Platta y vissitador general de esta provinçia del Tucuman por expesial comission del Rey nuestro señor etcetera. Dijo que en la vissita que hisso en los pueblos de la juridission de la ciudad de Cordova pronuncio sentensia en la causa de los indios del pueblo de Guaiascatte en ocho del mes passado de abril de este presente año que mando a don Leandro Ponze de Leon encomendero de dicho pueblo que dentro de seis meses acavase la capilla y pussiese en estado de que se dijese missa con desensia de que le remitiesse testimonio pena de que prosedera por todo rigor de derecho cuya sentenssia se le notifico en dicho dia ocho de abril y que consintio sin reclamar ni pedir mas termino para el efecto referido y respecto de que abiendo dado comission al capitan don Manuel de Zevallos Netto y Estrada para la ejecussion desta y las demas sentenssias parese por el testimonio que le remiti no aver cumplido el dicho encomendero con lo mandado sin embargo de estar passado [68v] el termino asignado y para que la dicha sentencia no sea ylusoria y tenga cumplido efecto manda su merced dicho señor oydor vissitador general que a costa de los vienes del dicho don Leandro se lebante la dicha capilla y que los indios no le acudan con los tributos hasta tanto que [entrelíneas: se] haia acavado y este en perfession y que los cobre y retenga en si el capitan Juan Lopes de Fuente Seca rexidor perpetuo de la ciudad de Cordova y protetor general de los naturales lo qual executara en conformidad de la comission que le tiene dada el dicho capitan don Manuel de Zevallos a quien en caso nesesario la da de nuebo para el efecto referido y aprobo lo demas obrado por el dicho jues comissario en quantto a que el dicho encomendero no se sirva de los muchachos y los ponga en su pueblo y redusion y assi lo proveyo y mando. Don Anttonio Martines Luxan de Bargas. Antte mi Lorenso Pintto escrivano rezeptor.

[Al margen: Autto]

En la ciudad de Cordova provincia de el Tucuman en sinco dias del mes de febrero de mill y seissienttos y nobenta y quatro años el capitan don Manuel de Zevallos Neto y Estrada alguasil maior de esta ciudad y jues de comission para la execussion de las sentensias dadas por el señor 
doctor don Antonio Martines Luxan de Bargas del consejo de su magestad [69r] y su oydor mas antiguo en la real audiencia de la Platta y vissitador general en esta provincia del Tucuman por espessial comission de su magestad abiendo resevido el auto de susso proveido por dicho señor vissitador general tocante a la que pronuncio contra el maestre de campo don Leandro Ponse de Leon encomendero del pueblo de Guaiascate y visto lo que en cumplimiento de dicha sentencia su señoria ordena y manda que para su execussion se allava de proximo a ponerse en viaje a dicho pueblo de Guaiascate por quanto oy a sido notissiado se halla en esta dicha ciudad el dicho encomendero para su mas breve execussion y juntamentte ahorrarle de costas mando su merced a mi el presentte escrivano le notifique al dicho don Leandro Ponze de Leon el dicho autto nuebamentte proveido por dicho señor oydor y vissitador general para que le conste lo que en el se le ordena y manda junto con este en su virtud probeido por su merced de dicho jues comissionario en el cual le ordena y manda de rason si tiene dado se [sic] debido cumplimiento en la fabrica de dicha capilla dentro de segundo dia para con su respuesta probeher en justissia y en el ynterin no salga de esta dicha ciudad en sus pies ni en axenos pena de sinquenta pesos aplicados camara de su magestad y que despachara a su costa con las demas diligencias que en el caso com[69v]bengan asi lo probeyo mando y firmo. Don Manuel de Zevallos Netto y Estrada. Antte mi Luis Izquierdo de Guadalupe escrivano publico y de cabildo.

[Al margen: Notificacion]

En la dicha ciudad de Cordova en dicho dia mes y año arriba dichos yo el presente escrivano ley y notifique los autos de retro segun y como se contienen al maestre de campo don Leandro Ponze de Leon vezino, de esta ciudad en su persona que dixo los oya y entendia su thenor y que de ellos suplicava para antte su señoria, de dicho señor oydor y bissitador general por causas que tenia para ello y dicha suplica y esta respuesta lo aria por escrito en forma de ello doy fee. Luis Izquierdo de Guadalupe escrivano publico y de cavildo.

[Al margen: Peticion]

El maestre de campo don Leandro Ponze de Leon vezino feudetario desta ciudad y encomendero del pueblo de Guaiascate paresco ante vuestra merced y digo que el presente escrivano de cavildo me notifico un autto por vuestra merced probeido en comformidad de otro proveido en la ciudad de Saltta por el señor don Antonio Martines Luxan de Bargas del consejo de su magestad su oydor mas antiguo de la real audiençia de La Platta y vissitador general de las encomiendas de esta provinçia sobre de ser no es cumplido con lo que se me mando en la vissita hisiesse la iglesia en el pueblo de dichos mis encomendados dentro seis meses y lo demas dedu[70r]sido en dichos autos y presupuesta su narracion ablando con el respeto devido suplico y apelo de dichos autos para antte su señoria dicho señor vissitador por lo gravoso que me son y por lo general y siguientte lo primero porque le es notorio a dicho señor vissitador que tengo la iglesia en estado de aserla pues estan los simientos hechos y lebantados mas de una bara en altto desde antes que su señoria viniese a la vissita y el no proseguir a acabarla assido por no aver querido los indios mis encomendados asistirme ni aserla aunque les hecho ynstanssias de palabra por estar yo privado de entrar en el pueblo y ser materia ympossible aserla sin asistencia lo otro porque por vuestra merced se me quitaron dos muchachos que me assistian para condusir las maderas para la dicha iglesia mandandoles no me asistiesen y es verdad publica y notoria que tengo en dicho pueblo las maderas y adoves echos prevenidos para dicha fabrica pero sin permiso para la asistencia y que a dichos indios se les apremie que me aiuden a aserla no sera possible y fasilitado lo dicho con prolongassion de otros seis meses se podra acavar dicha iglesia donde no protesto no me pare por juissio lo mandado por vuestra merced por lo qual a vuestra merced [70v] pido y suplico se sirva admitirme la suplica que ago y otorgar la apelassion que interpongo admitiendome las rasones que espresso para no aver acudido o proseguido en dicha yglesia y acavadola por declaradome, por justamente satisfeecho al cargo por ser de justissia la qual pido y de no se me de testimonio 
de este escrito por todo a el probeido para ocurir antte dicho señor vissitador que protesto costas y lo a que protestar devo puedo y necensardo [sic] en este papel blanco a faltta de no aver sellado para el casso etcetera. Don Leandro Ponze de Leon.

[Al margen: Auto]

En la ciudad de Cordova provincia del Tucuman en ocho dias del mes de febrero de mill y seissienttos y nobentta y quatro años antte el capitan don Manuel de Zevallos Netto y Estrada alguasil maior de esta ciudad y jues de comission en tocantte, al señalamientto de tierras y sittuasiones de capillas y execuzion de las sentensias en esto y demas expresado en ellas que imcumbe a los [testado: encomenderos] de esta ciudad en la vissita que hiso el señor doctor don Antonio Martines Luxan de Bargas del consejo de su magestad y su oydor mas antiguo en la real audiencia de La Platta vissitador general en esta provincia por expecial comission de su magestad se presento esta petizion [71r] por el maestre de campo don Leandro Ponze de Leon y haviendola visto dijo que atentto a que esta parte no a cumplido con el thenor de la sentencia pronunciada por dicho señor vissitador general en razon de no haver hecho la igleçia del pueblo de Guaiascatte dentro del termino asignado y el autto ultimo proveido por su señoria en la ciudad de Salta su fecha en veinte y dos de noviembre del año passado de seissientos y nobenta y tres en que mando que el dicho maestre de campro don Leandro Ponze de Leon haga la dicha igleçia a su costa con las calidades prevenidas en el dicho autto que se le notifico en cuia consecuençia mando que el curaca de dicho pueblo no acuda con los tributos al dicho encomendero y entren las tassas en poder del protetor general con quentta y razon y para ello se les notificara y que dicho encomendero cumpla por su partte lo que se alla mandado sin embargo de la apelazion que interpone que a maior abundamientto declaro no haver lugar por no ser mas que mero executor de lo probeido y determinado en definitiba de dicha vissita y lo firmo. Don Manuel de Zevallos Netto y Estrada. Ante mi Luis Izquierdo de Guadalupe escrivano publico y de cabildo.

Y luego incontinenti en el dicho dia mes y año a [71v]rriba dichos yo el presentte, escrivano ley y notifique el autto de suso como en el se contiene al maestre de campo don Leandro Ponse de Leon en su persona que lo oyo y entendio dello doy fee. Don Luis Izquierdo de Guadalupe escrivano publico y de cavildo.

[Al margen: Notificacion]

En la ciudad de Cordova en diez dias del mes de marzo de mill y seissientos y nobenta y quatro años yo el pressente escrivano hise notorio el autto de suso al capitan Juan Lopez de Fuentte Seca rexidor y protetor general de los naturales en su persona dello doy fee, Luis Izquierdo de Guadalupe escrivano publico y de cavildo.

[Al margen: Escriptura de asignasion de tierras a los mocobies del maestre de campo don Henrrique de Sevallos]

Sea notorio a los que la presente cartta y publica escriptura de donazion y señalamientto de tierras vieren como yo el capitan don Henrique de Sevallos Estrada vezino feudetario desta ciudad de Cordova provincia de Tucuman otorgo y conosco por la presentte, y digo que por quantto al tiempo y quando se me dio titulo y encomienda de los indios y familias de nazion toba desnaturalissados con las armas de su magestad de la probincia del Chaco assi en remunerazion de mis servisios personales como por conposision de algunas de dichas familias con entero en las reales cajas fue una de las condiziones de dicho titulo el [72r] haver de señalar tierras para pueblo y reducion de dichos indios mediante lo qual y respecto de aver al presentte hasta quatro familias por la fuga que hicieron los demas a sus tierras y haverse muertto y para que las tengan con sitio señalado donde hazer reduzion y sementeras cumpliendo con la dicha clausula y gravamen poniendolo en efecto haviendo presentado petission antte el maestre de campo Juan de Perochena thenientte general justissia mayor y capitan aguerra desta provinçia para que 
mandase, al protector de naturales asistiese a azetar esta donaçion y por su merced visto mando que el capitan don Juan de Tejeda como tal protetor acudiesse a lo referido y abiendose hecho las diligencias por el presentte escrivano para el dicho efecto pareze ser havia hecho auziencia a sus haziendas por cuya caussa y lejitimo impedimentto por auto de cattorse deste mes proveido por dicho thenientte general nombro por tal protetor para lo referido y demas diligencias de azetacion y posesion al capitan Bernardo de Zevallos quien lo azecto y juro en forma como todo mas largamentte consta de dicha petission y obrado que sacado a la letra es del [72v] thenor siguientte.

[Al margen: Peticion]

El capitan don Henrique de Zevallos Estrada vezino feudetario desta ciudad de Cordova paresco ante vuestra merced y digo que al tiempo y quando se me hizo la encomienda y merced real de composision y remunerazion de servicios de los indios y familias de nasion toba desnaturalissadas con las armas de su magestad de la provincia del chaco, fue con gravamen y calidad de averles de señalar sitio para su reduzion y sementeras y respecto de que con la ocassion de haver comprado a gran costa de mi caudal una estancia, [testado: como] tres leguas poco mas desta ciudad que en ella quiero donar y señalar ojos de tierras para sus sementeras medio quartto de legua de norte a sur y para sus ganados las que se contendran en dicha donazion atendiendo a haver quedado hasta quatro familias por la fuga que hizieron a sus mesmas tierras y muerto en esta ciudad y para que haya persona que representando la de dichos yndios azette estta donazion y se le mande dar la possesion judisial. Pido y suplico a vuestra merced se sirva de mandarles al protector de naturales azette y se alle presentte al otorgamientto de la dicha donazion y en todo justissia y en lo nessesario etcetera. Don Henrique de Zevallos Estrada.

[73r] [Al margen: Decreto]

El protector de naturales desta ciudad que lo es el capitan don Juan de Tejeda Guzman rexidor propietario desta ciudad asista al otorgamiento de la escriptura que don Henrique de Zevallos ha de haser a favor de sus indios y en todo acuda a la obligaçion de su ofiçio mirando el maior aumentto de los naturales en comformidad de reales çedulas y ordenanças y fecha la donaçion se traiga para proseguir a las demas diligencias que combengan. Juan de Perochena proveyo y firmo el decretto de susso el señor maestre de campo Juan de Perochena theniente general justissia mayor y capitan haguerra de esta provincia del Tucuman por su magestad en Cordova a catorze dias del mes de agosto de mill y seissientos y ochenta y quatro años. Antte mi Anttonio de Quixano Velasco escrivano de su magestad.

[Al margen: Dilixencia]

En la ciudad de Cordova a catorze dias del mes de agosto de mill y seissientos y ochenta y quatro años yo el presente escrivano haviendo venido a las cassas de morada del capitan don Juan de Tejeda Guzman rejidor propietario desta ciudad y protector general de los naturales para efecto de notificarle el decreto de esta foxa proveydo por el señor theniente [73v] general y preguntando por el a la jentte de su servissio me respondieron no estar en la ciudad y haverse hido a sus haziendas donde no les pareçia bolber breve y para que conste lo pongo por diligencia testigos los capitanes Bernardo de Zevallos, Juan Lopes de Fuentteseca y Francisco Lopes del Barco que se allaron presentes a esta diligencia Anttonio de Quixano Velasco escrivano de su magestad.

[Al margen: Autto]

En la ciudad de Cordova en catorze dias del mes de agosto de mill y seissientos y ochenta y quatro años el señor maestre de campo Juan de Perochena thenientte general justissia maior y capitan aguerra de esta provincia del Tucuman por su magestad que Dios guarde haviendo visto la 
diligencia hecha por el presentte escrivano y fee dada de no estar en la ciudad el capitan don Juan de Tejeda protector de naturales en ella por cuya caussa y para que se aga la escriptura de donacion y señalamientto de tierras a los indios encomendados del capitan don Henrique de Zevallos es pressiso nombrar persona que por dicha auziencia e impedimentto la azette y aprehenda la [testado: posesion] y con quien se hagan las demas diligencias nesesarias por el presentte dijo su merced que nombrava y nombro por protector para esta caussa y diligencia al capitan Bernardo de Zevallos morador desta ciudad persona que [74r] assido protector general de los indios della y de los demas de esta governacion y se le notifique lo azette y jure pena de sinquenta pesos aplicados a la real camara de su magestad y fecho asistira al otorgamientto y azetazion de escriptura que se ha de hazer en comformidad del pedimentto de la foxa de atras y assi lo proveyo mando y firmo Juan de Perochena. Antte mi Antonio de Quixano Velasco escrivano de su magestad.

[Al margen: Notificacion azeptacion y juramento]

En Cordova en catorse de agosto de seissientos y ochenta y quatro años yo el presente escrivano estandolo el capitan Bernardo de Zevallos le ley e hize saver el nombramiento de protetor en su persona hecho en el autto de susso y habiendolo oydo y entendido dijo que le azetava y azecto y juro por Dios nuestro señor y una señal de cruz segun de derecho de que usara dicho ofisio a todo su leal saver y entender y a su conclussion dijo si juro y amen y lo firmo dello doy fee. Bernardo de Zevallos. Anttonio de Quixano Velasco escrivano de su magestad.

[Al margen: Prosigue la escriptura]

En cuia comformidad otorgo que señalo hago grasia y donaçion a favor de dichos indios de nazion toba mis encomendados a ellos y a los que adelante les subcedieren en qualquiera manera que sea para que hagan dicha redusion y sementeras para mera perfecta ynrrebocable de las que el derecho llama ynter vibos y parttes presenttes conviene a saver de medio quarto de legua [74v] en las tierras y estancia que poseyo llamada de Saldan tres leguas desta ciudad poco mas o menos yendo de aqui para la dicha estançia en el arroyo prinsipal que corre por ella de esta partte, el qual dicho medio quarto de legua corre de nortte a sur sin que en manera alguna ayan de pasar a la otra banda de dicho aroyo que excetuo para mis ganados y poblazion con las demas contenidas en los instrumentos de compra, y ha de ser dicho arroyo lindero fixo y permanentte entre dicho pueblo que asi se a de fundar y mi estançia el qual medio quarto de legua ha de comenzar desde la punta y ançon que hase una cañada a la falda de unas lomas corriendo al sur que son comodas para dicho pueblo y sementeras con ojos de tierras aguadas y montte y asimesmo para sus ganados les doy un quarto de legua mas hazia la pampa que sale como venimos de dicha estançia a esta dicha ciudad hazia el camino real que va a la de Santiago del Estero todo lo qual se les ha de enterar medido a cuerda, para que sepan lo que assi han de gozar y tener por reduzion y tierras propias con lo qual y declarazion referida desde que esta carta de donazion es fecha para siempre jamas me desisto, quito, y apartto desapodero y abro mano de dicho quartto [testado: y medio] de tierras en la forma que arriba ba referido sin que en ningun tiempo dichos indios ni subcesores pretendan ni puedan pretender derecho alguno por [75r] ninguna caussa ni otro pretesto a las demas tierras y estancia que asi tengo poblado ni en passar a la otra banda del dicho arroyo y por el mismo casso si lo tal yntentaren desde luego declaro por ninguna esta donazion y mediante ella abro mano de la tenencia propiedad posesion dominio señorio y otras acciones que a dicho quarto y medio de tierras he tenido y tengo [repetido: y tengo] y todo ello lo zedo renunçio y traspaso en dichas familias de nazion toba mis encomendados y subcesores para que de como cossa suya havida y adquirida con justo y derecho titulo como lo es el de esta donazion las pueda desde luego entrar a poseer y cultibar con tal condizion que en manera alguna las puedan vender ni enajenar con ningun pretesto respecto de aver de quedar despues de la ultima vida de mi subçesor permanenttes en dichas tierras con la servidumbre a quien las poseyere si es que se 
puedan agregar conforme a los auttos generales proviciones por bia de buen gobierno a que en lo nessesario me remitto y les doy poder y facultad qual se requiere para que el casique de dichas familias y su protector en su nombre tomen y aprehendan la poçeçion de dicho quartto y medio de tierras y en el interin me constituyo por su inquilino y me obligo a todo lo de eviçion y saneamientto en forma y de que les seran ciertas y seguras y de no [75v] rebocar esta donazion por testamentto ni en otra manera, y de sacarles a paz y salvo de qualquier embaraso y contradission que se les yntentare poner y si les saliere ynsiertas les dare y señalare otras tantas tierras en paraje tal y tan bueno y en la cantidad que ba espresada, a cuyo cumplimientto obligo mi persona y vienes muebles y raizes havidos y por haver doy poder cumplido a las justissias y juezes de su magestad de todas y qualesquier parttes y lugares que sean a cuyo fuero y juridicion me sometto renuncio el mio propio domisilio y vesindad y la ley que dize que el actor deve seguir el fuero del reo las demas de mi favor con la general y derechos della para que asi me lo hagan guardar cumplir y ejecutar como si fuesse por senttencia difinitiva de juez conpettente dada y passada en authoridad de cosa juzgada consentida y no apelada. Y en esta forma y presentte el capitan Bernardo de Zevallos protetor nombrado y como tal en nombre de dichos indios de nazion toba azecto esta donazion de tierras declarando como declara ser las suficienttes para dichas familias por ser cortas y en la forma que se an señalado a otros indios en cuyo testimonio ambos a dos lo otorgamos cada uno por lo que nos toca que es fecho en esta ciudad de Cordova, en quinze dias del mes de agosto de mill y seissientos y ochenta y quatro años por los [76r] otorgantes a quienes yo el escrivano de su magestad doy fee conosco lo firmaron siendo testigos los capitanes Francisco Lopes del Barco Juan Lopez de Fuenteseca y Francisco de Salaverria, pressenttes. Don Henrique de Zevallos Estrada. Bernardo de Zevallos. Antte mi Anttonio de Quixano Velasco escrivano de su magestad.

Paso antte mi y en fee dello lo signo e firmo. En testimonio de verdad. Anttonio de Quixano Velasco escrivano de su magestad.

[Al margen: Peticion]

El capitan Bernardo de Zevallos protetor por vuestra merced nombrado por auciencia del capitan don Juan de Tejeda Guzman que lo es de los naturales de esta ciudad para que en nombre de los encomendados al capitan don Henrrique de Zevallos Estrada de nasion toba desnaturalizados con las armas de su magestad Dios le guarde, de la provincia del Chaco azettase la donaçion de tierras que les hiso en conformidad de su titulo y encomienda real para pueblo y reducion de dichos indios la qual se les hiso que es de la que hago demostrazion, en devida forma para que vista por vuestra merced se sirva de mandar despachar su comision a la persona que fuere servido para que de la posesion de dichas tierras contenidas en dicha donaçion a dichos indios y a mi en su nombre para que en ellas puedan librementte haser su pueblo y reduzion por ser como son sufisientes para ellos y comodas para sementteras con leña y lo demas nesesario a su natural por lo qual a vuestra merced pido y suplico provea y [76v] mande segun que pido en que mis parttes y yo en su nombre reseviremos merced con justicia. Bernardo de Zevallos.

[Al margen: Decreto y comision]

Abiendo visto este pedimento presentado por el capitan Bernardo de Zevallos protector nombrado juntto con la donazion echa por el capitan don Henrrique de Zevallos Estrada a favor de los indios de donazion tobas que gosa por encomienda real que tiene pressentada y de constar en ella el señalamientto de tierras y aguadas que les haze para su pueblo y sementeras en conformidad de dicho tittulo y reales hordenansas y de ser temperamentto a propossitto para lo qual y que dichos indios y su casique aprehendan la posesion real judizial de dichas tierras y su protector por ellos doy comision cumplida vastantte de derecho nezesario al alferez Pedro de Lossa para que alzando bara real justissia baya a la estancia de Saldan y en las tierras que en la donacion se allan señaladas se la de en la forma hordinaria dandoles a entender a dichos indios 
por su protetor quedar para dicho su pueblo sementeras y aguadas perpetuamentte, sin haver de haser mudanza por si y constando de haverla aprehendido se les ampara de la qual no sean desposseidos sin primero ser oydos y por fuero y derecho venzidos pena de quinientos pesos aplicados a la real camara de su magestad en que desde luego se dan por incurrsos lo contrario haziendo y dese a dicho [77r] curaca y su protector los testimonios que pidieren con ynsercion de todo. Juan de Perochena. Proveyo y firmo la comision destas dos foxas el señor maestre de campo Juan de Perochena theniente gueneral justissia mayor y capitan aguerra desta provincia del Tucuman por su magestad.

[Al margen: Posesion]

En Cordova a quinze de agosto de mill y seissienttos y ochenta y quatro años antte mi Anttonio de Quixano Velasco escrivano de su magestad estando en la estancia llamada de Saldan haziendas del capitan don Henrrique de Zevallos tres leguas poco mas de la ciudad de Cordova en veinte y sinco dias del mes de septiembre de mill y seissientos y ochentta y quatro años por antte mi el escrivano de su magestad y testigos de yusso el capitan Bernardo de Zevallos protector nombrado requirio con la comission y mandamiento de estas dos foxas despachado por el theniente general desta provinçia al alferez Pedro de Lossa contenido en ella para que le aga dar y de la poseçion real y judicial de las tierras contenidas en la escriptura de donacion hecha por el dicho capitan don Henrrique de Zevallos a favor de sus indios encomendados de nazion toba desnaturalissados de la provincia del chaco para que hagan reducion y sementeras en el sitio paraje y linderos de dicha donacion y vistos por [77v] dicho alferez Pedro de Lossa azetando como azetto la dicha comission haviendo hido al paraje y arroyo que passa por esta [tachado: partte] estancia de la otra vanda del, yendo para la ciudad de Cordova saliendo de dicha estancia y donde al presentte tiene hecho un rancho don Juan casique de dichos indios en un ancon que hase la cañada viniendo de la dicha ciudad cercano a unos corrales grandes de piedra que estan anttes de llegar a dicho aroio, que es el lindero fixo y permanentte medio quartto de legua para la dicha reducion y sementeras corriendo de nortte a sur y otro quartto mas para sus ganados coriendo a las pampas que ba a salir al camino real que ba para la ciudad de Santiago del Estero y en esta forma por ser la que contiene la donazion cojio dicho juez de comission por la mano a dicho protetor nombrado en presencia de dicho curaca y les dio la posesion real actual y judicial de dicho quartto y medio de tierras de dia claro y como a las tres de la tarde poco mas o menos sin contradicion del dicho capitan don Henrrique de Zevallos que esta presentte por referir ser las mesmas de que ha hecho donazion a sus encomendados y dicho protector en nombre de sus partes arranco yervas e hizo otros actos acostumbrados en semejanttes posesiones y de como lo tomava y aprehendia lo pidio por tes[78r]timonio yo el escrivano se lo doy por aver passado en mi presencia y dicho comisonario mando no sean dichos indios desposeydos dellas sin primero ser oydos y por fuero y derecho venzidos so las penas contenidas en dicha comision y lo firmo de su nombre juntto con dicho protetor nombrado siendo testigos el capitan don Henrrique de Zavallos, Nicolas Juarez y Migel Suares Pedro de Lossa Bravo. Bernardo de Zevallos. Ante mi Anttonio de Quixano Velasco escrivano de su magestad.

Concuerda con los originales que para efecto de sacar este exivio antte mi el maestre de campo general don Enrrique de Zevallos Neto y Estrada del orden de Santiago alferes real de esta ciudad con los quales de su pedimento los fize corregir y consertar y corregi y consertte y a ellos en lo nesesario me remito y di el presentte en Cordova a dies y [testado: siette] de febrero de mill y seissientos y nobentta y cuatro años en este papel comun a falta de sellado y a ello fueron testigos don Pedro de Olmos, Migel Maldonado y Fransisco de Salaverria. Y en fee de ello lo signo y firmo en testimonio de verdad don Luiz Izquierdo de Guadalupe escrivano publico y de cavildo.

[Al margen: Reconosimiento de las tierras y pueblo de los indios tobas del maestre de campo Henrique de Zevallos] 
En las tierras de Saldan pueblo y reduzion de los indios tobas desnaturalisados de la provincia del Chaco encomienda del maestre de campo general don [78v] Henrique de Zevallos Netto y Estrada cavallero del orden de Santiago y alferez real propietario de la ciudad de Cordova tres leguas poco mas o menos de la dicha ciudad de Cordova en trese dias del mes de febrero de mill y seissientos y nobentta y quatro años yo el capitan don Manuel de Zevallos Netto y Estrada alguazil mayor propietario de la dicha ciudad y juez de comision nombrado por el señor doctor don Antonio Martines Luxan de Bargas del consejo de su magestad su oydor mas antiguo de la real audiencia de la ciudad de la Platta y vissitador general de esta provincia del Tucuman por expesial comiçion del Rey nuestro señor para la execuçion de las sentencias dadas a los besinos feudetarios de esta dicha juridizion y por lo que toca a la pronunciada contra el [entrelíneas: dicho] maestre de campo general don Henrrique de Zevallos su fecha en la dicha ciudad de Cordova en quinze dias del mes de abril proximo pasado de nobentta y tres años vine a este dicho pueblo con asistençia del capitan Juan Lopes de Fuentte Seca rexidor y protector general de los naturales para el reconosimientto y vista de ojos mandada hazer por dicha centençia de las tierras donadas por el dicho encomendero a los dichos indios de esta encomienda en dicha ciudad de Cordova en quinze dias del mes de agosto de mill y seissienttos y ochentta y quatro años por antte Anttonio Quixano Belasco escrivano de su magestad como consta de dicha escritura pose [79r] sion y demas dilixencias en su birtud hechas que exivio antte mi el dicho encomendero cuyas tierras reconosimos y hallamos tenerlas pobladas los dichos yndios con ranchos corrales y sementeras de mays que al presentte hallamos tener sembrada con otras legumbres para sus aprovechamienttos y sin enbargo de ser frutiferas y comodas con agua sufisiente para su utilidad y grangerias en atension de que los indios que ai en esta reduzion al presentte son ocho con dos resserbados y consta y por dicha donazion tener este dicho pueblo quartto y medio de legua debajo de los linderos conttenidos en dicha dotacion y tener nesesidad de mas tierras por aver cresido el numero de dichos indios despues que se hizo la dicha donazion mando al dicho encomendero les de a los dichos sus indios otro medio quarto de legua que (tiene asignado) corra, sobre el quarto de legua que tiene asignado hasia la campaña que corre açia el camino real que ba de la dicha ciudad de Cordova a la de Santiago de Estero de manera que ayan de tener desde el arroyo conthenido en dicha donazion hazia la panpa y dicho camino real que ba a Santiago del Estero quartto y medio de legua por tener buenas cañadas y monttes para sus aprovechamientos. Lo qual oydo y enttendido por dicho encomendero atendiendo a la [79v] mayor utilidad de dichos yndios sus encomendados dijo que azeptava y azepto el dar y señalar a los dichos sus encomendados el medio quartto de legua en la forma y manera que ba expresado y a mayor abundamientto siendo nesesario desde luego les hazia e hizo gracia y donazion pura mera perfecta e inrrebocable debajo de las claussulas y condissiones contenidos en la donazion que les tiene fecha y ba expresada y devajo de ellas les hase esta em publica forma. Y en [entrelíneas: su] conformidad el dicho protetor general dijo que lo azeptava en nombre de sus parttes y por ser de su satisfacion y combenienzia de sus parttes debajo de la posesion judizial que de ellas tienen tomada y para que todo conste a dicho señor oydor y visitador general mando que de dicha donazion posesion y demas dilixencias se pongan un tantto con esta autorisado en publica forma y por lo que toca a las pagas mandadas hazer a los indios que an servido a dicho encomendero de quatro pesos a cada uno y tres a las indias que an estado en su cassa, y un pesso a cada una de las de esta reduzion en atencion de averlos echo parezer antte mi y a don Juan su curaca, quienes confesaron con su protector averlos resevido en presençia del escrivano rezeptor de vissita y en su birtud declaro al dicho encomendero haver cumplido con este cargo. Y en quantto a la [80r] capilla mandada hazer en dicha sentencia por quanto e reconossido a vista de ojos no aver dado su cumplimientto el dicho encomendero y preguntandole la caussa o motivo porque no avia cumplido con su obligazion en conformidad de la ordenanza beintte dijo que no la a savido por no averla visto pero que agora que se le a echo notoria cumplira con ella y sin enbargo de su respuesta mando cumpla con esta obligasion dicho encomendero y en el entre tanto que no 
hiziere dicha capilla le declaro por incursso en la pena de la dicha ordenanza beintte y remitase testimonio a dicho señor oydor y vissitador general a costa del dicho encomendero y para que conste lo firme por ante mi y testigos a falta de escrivano siendolo pressentes a todo lo referido el sargento mayor Sevastian de Arguello fiel executor y los capitanes Cristobal de Funes y Ludueña vessinos feudetarios y Bernardo de Zevallos que con las partes lo firmaron conmigo y en este papel comun a falta del sellado doy fee don Manuel de Zevallos Netto y Estrada. Juan Lopes de Fuente Seca. Don Henrrique de Zevallos Netto y Estrada. Sevastian de Arguello. Cristobal de Funes. Bernardo de Zevallos.

[Al margen: Autto sobre la asignazion de tierras de los indios de Alonso Luxan]

El capitan don Manuel de Zevallos Netto y Estrada alguasil maior y jues de comission nombrado por el señor dotor don Anttonio Martines Luxan de Bargas del [80v] consejo de su magestad su oydor mas antiguo de la real audiencia de la ciudad de La Platta y vissitador general de esta provincia del Tucuman por expecial comision del Rey nuestro señor para la execussion de las sentencias dadas a los vezinos encomenderos de esta dicha juridicion y por lo que toca a la proveyda contra el capitan Alonso Luxan de Medina que con asistencia del capitan Juan Lopes de Fuentte Seca, rejidor y protector general de los natulas [sic] vine a executar y aviendo llegado a su estancia de San Marcos en donde a de azer la asignacion de las que pertenesen a sus encomendados y no aviendo allado en ella al susodicho y averme imformado se alla en la estancia de Maza distantte de esta sinco leguas poco mas o menos mando al dicho capitan Alonso Luxan de Medina que luego y sin dilazion venga a dicha su estancia a haser la dicha asignacion de tierras junto con su mujer cumpliendo en todo segun que es obligado por dicha sentencia que le esta notificada con apersevimientto que de no proveer lo que combenga a favor de dichos indios y se le apersive costas y salarios en las que por su omission se recrecieren y para que les conste y tenga cumplido efecto se le notifique por mi dicho alguazil maior i juez; yendo para el efecto en presensia assi lo proveyo y mando y firme por antte mi y testigos a falta de escrivano y en este papel comun a falta del sellado que es fecho en [81r] esta dicha de San Marcos en dies y seis dias del mes de febrerro de mill y seissienttos y nobentta y quatro años don Manuel de Zevallos Netto y Estrada Franssisco Anttonio de Camino.

[Al margen: Notificacion]

En la estancia de Maza sinco leguas de la de San Marcos poco mas o menos juridision de la ciudad de Cordova en dies y seis dias del mes de febrero de mill y seissienttos y nobentta y quatro años yo el capitan don Manuel de Zevallos alguazil mayor y juez en comformidad del autto de susso por mi proveydo vine a esta dicha estançia en donde halle al capitan Alonsso Luxan de Medina enfermo al pareçer y le ley y notifique dicho autto y requeri segun su tenor cumpla con el segun es obligado y el susodicho aviendolo oydo y entendido dijo que al pressentte y de muchos dias a esta partte se alla muy malo e impossibilitado por la gravedad de su achaque a podersse poner en camino ni aun en carretta que es el mas comodo y solo el deseo de mejorar fue causa de venirse de su estancia a esta dicha en busca del medico por tener aqui su asisttencia y no ha podido mejorar anttes si con mucha peoria por cuya causa y cargo achaque tiene juntto con doña Maria de Olmos y Aguilera su muger otorgado poder bastantte para la asignaçion de tierras que deve a sus encomendados al maestre de campo don Bartolome de Olmos y Aguilera su suegro que tiene azeptado por cuya causa y rasones referidas pide y su[81v]plica, asista en su nombre y la dicha su muger a la dicha signasion que deve haçer porque la que el susodicho hiziere, da por buena, y juro a Dios y a esta cruz ser sierta y no de malisia y lo firmo conmigo y testigos pressentes el dicho maestre de campo don Bartholome de Holmos y Aguilera el capitan don Joseph de Olmos y Aguilera y Francisco Anttonio de Camino. Don Manuel de Zevallos Netto y Estrada. Alonsso Luxan de Medina. Don Bartholome de Olmos y Aguilera. Don Joseph de Olmos y Aguilera. Francisco Anttonio de Camino. 
[Al margen: Poder]

Sea notorio a los señores que la presente carta y escriptura de poder vieren como nos el capitan Alonso Luxan de Medina vesino feudetario de esta ciudad y doña Maria de Olmos y Aguilera su legitima mujer con lisencia que yo la dicha doña Maria pido al dicho mi marido para hazer y otorgar lo que de suso se contendra y yo el dicho capitan Alonsso Luxan de Medina saviendo para el efecto que me es pedida se la doy y consedo libre llenera y bastantte la que de derecho se requiere y es nesesaria y della usando yo la dicha doña Maria y ambos a dos marido y mujer junttos y de mancomun y cada uno de nos de por si y por el todo in solidum renunciando como expresamentte renunsiamos las leyes de duobus rex debendi y la autentica presentte hoc hita fide y usoribus y el beneficio de la divicion y escursion y todas las demas leyes fueros y derechos de la mancomu[82r]nidad otorgamos y conosemos que damos todo nuestro poder cumplido libre llenero y bastantte el que de derecho se requiere y es nesesario al maestre de campo don Bartholome de Olmos y Aguilera nuestro padre y suegro ausentte como si estubiera presentte para que, a caussa de estar enfermos en esta ciudad y como tal ympossibilitados de poder asistir personalmentte, al señalamientto y adjudicasion de las tierras que a los indios de nuestra encomienda se manda demos como consta en la sentencia del señor oydor doctor don Anttonio Martines Luxan de Valgas del consejo de su magestad y su oydor mas antiguo en la real audiencia de La Platta y vissitador general en esta provincia en la que hizo de los dichos indios por nos y en nuestro nombre y representando nuestra propia persona pueda señalar y con efecto señale y adjudique las dichas tierras señaladas en dicha senttençia y asista a que se midan y amojonen dichas tierras como si por nuestra persona señaladamentte y con nuestra presençia personal lo hisiesemos en la execusion que por comision particular para la datta y adjudicasion de dichas tierras esta actualmentte haziendo el capitan don Manuel de Zevallos Netto y Estrada alguasil mayor de esta ciudad y el capitan Juan Lopes de Fuentteseca rexidor y [82v] protector general de los naturales por su parte que la tal mensura amojonamiento deslinde adjudicasion y señalamientto de dichas tierras que por dicho jues de comission se hisiere en presensia y con asistençia de dicho poderitario nuestro y con su sitasion y actual presençia cada que conste la damos por bien hecha firme y baledora y en las clausulas y casos sircunstançias y acçiones juridicas que constare, afirmado y otorgado consentido y passado estamos y binimos en ellos porque en su persona y cabesa como tal nuestro podatario como si por nos y a nos se nos llamase a asistir para darla por firme balida y aprovada como si estubieramos presenttes a dicha mensura y adjudicaçion asi la damos por firme y queremos consentir y consentimos en ella en todo y por todo porque para todo lo anejo y conzernientte expeçial y particular que sea nesesario a la accion referida para faserla con toda firmesa juridicamentte, le damos poder cumplido sin limitasion alguna en todos los casos y cosas necesarias de sitasiones contradiziones aseptaziones asistencias deslindes de terminos señalamiento de sentro jurado o por jurar de la manera que combiniere y en fin sin reservar cosa dello que podamos alegar contra dezir o inrpugnar que para dicha men [83r]sura deslinde adjudicasion y datta real de las tierras dichas a los indios de nuestra encomienda aya sido nesesaria nuestra asistençia personal desa manera y con esa claridad y expresion damos este dicho poder al dicho maestre de campo don Bartholome de Olmos y a lo que por virtud del se ficiere por dicho jues comisionario con asistencia de dicho poderitario lo damos por balido y firme desde agora para siempre jamas en lo que toca a dicha mensura adjudicasiones deslinde de tierras y ella fecha por dicho poderitario consentida y siendo con su asistencia como ba referido nos obligamos en caso nesesario rebalidarla con escriptura y aun desde agora la rebalidamos pues a de ser con insersion de la dicha sentencia y este poder y a todo ello obligamos yo la dicha doña Maria todos mis bienes dotales arras y propter nuncias y los havidos y por haver asi muebles como raises y confieso que dicho poder para el dicho efecto lo doy de mi libre y espontanea boluntad y que ha ello no he sido biolentada ni induzida atrayda ni forzada con ruegos e insttancias sino que lo hago y otorgo librementte y yo el dicho Alonsso 
Luxan de Medina obligo mi persona y bienes havidos y por haver hasi los muebles como los raises y ambos damos poder a todas las justissias y jueces de su magestad de qualesquier parttes e juris [83v]dision que sean para que nos lo hagan guardar cumplir y executar como por sentencia definitiva de juez competentte consentida y no hapelada dada y passada en autoridad de cossa jusgada sobre que renunciamos yo la dicha doña Maria todas las leyes fueros y derechos de mi favor las del propio fuero domisilio y besindad y en expecial las leyes del emperador Justiniano y el veneficio del beleyano senattus consulttus nueba y viexa constitucion leyes de Toro y Partida que hablan en favor de las mujeres sus terminos y remedios para poder exclamar o pedir en contra de lo que aqui otorgo. Y yo el dicho Alonso Luxan de Medina renuncio todas las leyes fueros y derechos de mi favor y ambos la ley que dize que general renunçiaçion nonbala y yo la dicha doña Maria juro a Dios nuestro señor y esta señal de cruz que para otorgar lo aqui contenido no e sido indusida como ba expresado y dello no e echo esclamaçion ni la are en el todo ni en partte ni pedire relaxaçion de este juramentto a prelado que me la pueda y deva conseder y aunque [repetido: y aunque] de propio motu se me conseda no usar della pena de ser havida por perjura y tanttas quanttas beses se me consediere juro no la asetare y una mas en testimonio de lo qual lo otorgamos antte el presente escrivano [84r] publico y de cavildo de esta ciudad de Cordova en dies y ocho dias del mes de octubre de mill y seisientos y nobentta y tres años. E yo el escrivano que presentte fuy con los otorganttes doy fee los conosco y que asi lo otorgaron y firmo el que supo y por la otorgantte unos de los testigos que se hallaron presenttes que lo fueron el capitan don Pedro de Mendoza y el capitan don Luis Pacheco y Juan de Medina Aroyo y de pedimentto de los otorganttes no quedo en registro. Alonsso Luxan de Medina. A ruego de la otorgantte don Pedro de Cavrera y Mendoza. Passo antte mi presentte fui con los otorganttes y en fee dello lo signo y firmo en testimonio de berdad Luis Izquierdo de Guadalupe escrivano publico y de cavildo.

[Al margen: Peticion]

El maestre de campo don Bartholome de Olmos y Aguilera bezino encomendero de la ciudad de Cordova paresco ante vuestra merced en nombre del capitan Alonsso Luxan de Medina mi yerno y de doña Maria de Olmos y Aguilera mi hija lexitima y en virtud del poder que con esta presentto con la solemnidad y juramentto en derecho nesesario y digo que en cumplimientto de la senttencia que dio el señor doctor don Antonio Martines Luxan de Bargas del consejo de su magestad y su oydor mas antiguo de la real adiencia de La Platta y vissitador general de esta provin[84v]cia del Tucuman en la vissita que hiso de los indios calchaquies que posee mi partte en que se sirvio mandar asignaze tierras en la estancia de San Marcos con el agua sufisientte a satisfasion de vuestra merced y del protector general de los naturales en cuyo cumplimientto desde luego hago en nombre de mis partes en las dichas tierras de San Marcos de la parte de rio avajo desde el lindero que le toca segun el titulo de merced que de las dichas tierras tienen y poseen enterandoseles la media legua de tierras que manda el dicho señor visitador general por no aver en esta dicha reduzion mas que sinco yndios con dos que estan ausenttes por lo qual a vuestra merced pido y suplico me aia por presentado con dicho poder y en atencion de estar mi parte enfermo como a vuestra merced consta por la diligensia que tiene echa y en su conformidad se haga la dicha asignasion de tierras segun que pido que yo por lo que a mi toca la hago en nombre de mis parttes segun estan obligados y se manda por dicha sentensia pido justisia y para ello etcetera don Bartolome de Olmos y Aguilera.

[Al margen: Decretto]

Por presentada juntto con el poder que esta partte refiere y en comformidad se aga vista de ojos de las tierras que menziona por mi y con asistencia del protector general y siendo comodas y sufisienttes se midan y amojonen enterandose a los indios [85r] de esta reduzion media legua y medio quartto de legua sin enbargo de la media que señala para el numero de sinco yndios que 
dize ay con dos ausenttes en cumplimientto de lo mandado por el señor oydor y vissitador general asi lo provey y firme por antte mi y testigos a falta de escrivano y en este papel comun a falta del sellado que es fecho en esta estanzia de San Marcos en dies y siette dias del mes de febrero de mill y seissienttos y nobenta y quatro años. Don Manuel de Zeballos Netto y Estrada. Testigo Juan Lopes de Fuente Seca. Testigo Jasintto Luxan de Medina.

[Al margen: Asignacion de tierras a los indios de la encomienda del capitan Alonso Luxan de Medina]

En la estanzia y tierras de San Marcos del capitan Alonsso Luxan de Medina vessino feudatario de la ciudad de Cordova en su jurisdicion beyntte leguas poco mas o menos de la dicha ciudad en dies y siette dias del mes de febrero de mill y seissientos y nobentta y quatro años yo el capitan don Manuel de Zevallos Netto y Estrada alguazil mayor y jues de comission nombrado por el señor doctor don Anttonio Martines Luxan de Bargas del consejo de su magestad y su oydor mas antiguo de la real audiencia de La Platta vissitador general de esta provincia del Tucuman por expesial comission del Rey nuestro señor para la execusion de las [85v] senttensias dadas a los besinos encomenderos de esta juridicion y por lo que toca a la proveyda contra el dicho capitan Alonso Luxan de Medina en el paraje de Nonesacatte su fecha en catorze dias del mes de mayo el año passado de mill y seissienttos y nobenta y tres (años) y en comformidad de lo por mi probeydo oy dia de la fecha bine al paraje asignado por el maestre de campo don Bartholome de Olmos y Aguilera y en virtud del poder que antte mi tiene pressentado del dicho capitan Alonso Luxan de Medina y de doña Maria de Olmos y Aguilera su lexitima mujer con asistencia del capitan Juan Lopes de Fuente Seca rexidor y protector general de los naturales y de los (tres yndios) testigos de iusso y tres indios de esta encomienda y hisimos reconosimientto y vista de ojos de las tierras de San Marcos y reconosidas las que se señalan hallando que son frutisferas y comodas para sus sementeras y aprovechamienttos con el agua y monttes nesesarias y que las tienen al presentte pobladas Sebastian Domingo y Bernardo indios de esta encomienda mando se entere y amojone en ellas media legua y medio quarto de legua en quadro y en su execuzion se midio un cordel de cañamo de sinquentta baras y desde un algarobo que esta a la orilla del ryo frentte [86r] de las chacaras que fueron de Lorenzo de Ubeda y coxiendo desde dicho algarovo adonde hize labrar una cruz para que sirva de lindero, cojiendo el rumbo de la media partida del nordeste al este passando el rio hize medir treinta y siette cuerdas y media de dichas sinquenta baras que hazen un mill ochosientas y setenta y sinco baras que terminaron en unas lomas altas que corren de sur a nortte, a la parte del balle de Escoba y bolbiendo al dicho algarrobo hize medir azia la parte de Quilpo cojiendo el rumbo de la media partida del sudueste al ueste otras treinta y siette cuerdas y media de dichas sinquenta baras que con las otras del suso referidas hasen la dicha media legua y medio quartto de legua quedado por tieras desta reduzion el manantial y poblasion y parte de chacara que tubo el dicho Lorenzo de Ubeda. Y bolbiendo a la dicha loma alta cojiendo el rumbo de la media partida del nordeste al nortte hize medir setenta y sinco cuerdas de dichas sinquenta baras que hasen tres mill setesientas y sinquenta baras que son las que corresponden a la dicha media legua y medio quartto que terminaron sobre una loma alta al pie de un arbol de quiebra hacho adonde mande labrar otra cruz para que sirva de lindero y desde el cojiendo el rumbo de la media partida del sudueste al ueste se midieron otras setenta y sinco [86v] cuerdas de dichas sinquenta baras que son las que corresponden a la dicha media legua y medio quartto que terminaron en una sienega que esta juntto al camino real que ba a la ciudad de La Rioxa y en un sause que esta sobre dicha sienega hize labrar una cruz para que sirva de lindero. Con lo qual quedaron medidas y amojonadas dichas tierras y en conformidad de su asignazion las declaro por tierras y pueblo destos dichos indios debajo de los linderos referidos para que ussen dellas en todo aquello que fuere de su utilidad y conbenienzia en cumplimientto de leyes y hordenansas reales y en su birtud le di posesion de dichas tierras a un indio de esta [tachado: reduzion] encomienda llamado Sebastian por si y en nombre de los demas indios de ella 
que al presente son y adelantte fueren cojiendole de la mano y passeandole por ellas le di la dicha posesion en nombre de su magestad real actual corporal iure, domini, bel quassi en forma y segun derecho y el dicho indio Sebastian en señal que la tomava, aranco yerbas e hizo otros actos de posesion y mando a los que presenttes estavan se saliesen de ellas y se las dejassen libres y desembarazadas y de como tomo la dicha posesion de dia claro como a las quatro de la tarde, y sin contradision de persona alguna me pidio el dicho protector general [87r] en nombre de sus parttes se lo dieze por testimonio. E yo el dicho jues se le doy en quantto puedo y a lugar de derecho de aver sido y passado como dicho es y en su conformidad mando a todas y qualesquier personas de qualesquier estado calidad y condizion que sean no sean osadas a quitar ni mober los dichos mojones ni inquieten ni pertuben a los dichos indios de esta encomienda que al presentte son y adelante fueren de la dicha posesion sin que primero sean oydos y por fuero y derecho benzidos so las penas dispuestas por derecho y de duzientos pesos mas aplicados camara de su magestad en que desde luego les doy por incursos y condenados lo contrario haciendo. Y mando a los dichos indios e indias muchachos y muchachas esten en la dicha reduzion como de presentte los dejo a todos en ella, para que puedan con libertad travajar para sus utilidades cumpliendo en todo con lo mandado por dicho señor oydor y vissitador general en dicha sentencia teniendo cuydo [sic] el dicho encomendero en que oygan missa los dias de fiesta en la capilla que tiene echa en su estançia de San Marcos como se alla prevenido y mandado por dicho señor visitador general y el dicho maestre de campo don Bartholome de Olmos y Aguilera en nombre del dicho encomendero y en mi presensia y del dicho protector general hiso las pagas que devia haser de dies pesos a cada uno de los tres [87v] indios Sebastian, Domingo, y Bernave, que se les hiso en sesentta obejas a quatro reales en que pidieron se les hiziese por serles de su combeniençia. $Y$ asimesmo se les pago a siette indias que paresieron presenttes a quatro pesos a cada una que son las que ay en esta dicha encomienda y en su virtud se declaro por libre de esta obligasion al dicho encomendero. Y se obligo asimesmo en nombre de sus parttes y en virtud de dicho poder que tiene pressentado a que otorgaran instrumentto publico antte el escrivano de cavildo el dicho encomendero mancomunado con la dicha su mujer y a mayor abundamientto desde luego en nombre de sus partes les hasia e hiso a los dichos indios de esta reduzion grazia y donaçion de la dicha media legua y medio quartto de tierras en quadro de suso mensionadas y amojonadas pura mera perfecta e inrebocable de las que el derecho llama inter vistos y partes presenttes con las claussulas fuerzas y firmesas y condiziones dispuestas por derecho en cumplimientto de la obligacion que tiene el dicho encomendero de darles tierras con cuyo gravamen se le hiso la dicha merced y debajo de ella en nombre de sus partes hase esta dicha obligasion en publica forma con la de ebision y saneamientto y sumission a las justissias de su magestad para que a ello les compelan y apremien por todo rigor de derecho zerca de lo qual renunçia en nombre de sus [88r] partes qualesquier leyes fueros y derechos de su fabor en cuyo testimonio lo otorgo assi y [tachado: lo] firmo de su nombre conmigo dicho jues y protector siendo testigos presentes a todo lo referido Jazinto Luxan de Medina y don Franssisco Simon de Zevallos quienes lo firmaron conmigo a faltta de escrivano publico y en este papel comun a faltta del sellado doy fee. Don Manuel de Zevallos Netto y Estrada. Juan Lopes de Fuente Seca. Don Bartholome de Olmos y Aguilera. Testigo Jasinto Luxan de Medina. Testigo Don Francisco Simon de Zevallos Netto y Estrada.

[Al margen: Asignacion de tierras a los yndios del capitan Don Xriptobal Pisarro Albornos]

En la estansia de Cosquin del capitan don Cristobal Pisarro de Albornos juridizion de la ciudad de Cordova siette leguas de ella poco mas o menos en veinte dias del mes de febrero de mill y seissientos y nobenta y quatro años yo el capitan don Manuel de Zevallos Netto y Estrada alguazil mayor y jues nombrado por el señor doctor don Anttonio Martines Luxan de Bargas del consejo de su magestad su oydor mas antiguo de la real audiencia de La Platta y vissitador general de esta provincia de Tucuman por expesial comission del Rey nuestro señor para la execusion de las 
sentenzias dadas a los vessinos encomenderos de esta dicha juridision y por lo que toca a la proveyda contra el dicho capitan don Cristo[88v]bal Pissarro en dicha ciudad de Cordova en onse de abril del año passado de mill y seissientos y nobenta y tres años bine a esta dicha estanzia con asistencia del capitan Juan Lopes de Fuente Seca rexidor y protector general de los naturales y hizimos reconosimientto y vista de ojos de las tierras que asigna el dicho encomendero a los indios de su encomienda las quales en atension de que son frutiferas y con el agua sufisientte por caer sobre el rio y de la otra vanda de la estansia y cassas del dicho encomendero las ube por asignadas y en su comformidad mando se mida y amojone un quartto de legua en quadro en atension de ser tres indios los de esta encomienda y para su cumplimientto hize medir un cordel de cañamo de sinquenta baras y desde una esquina que aze el dicho rio desde unos peñones grandes adonde hize poner un mojon de piedras para que con dichos peñones sirba de lindero y cojiendo desde el, el rumbo del ueste quarta al sudueste se midieron dies y seis cuerdas de dichas sinquenta baras que terminaron en un sause que esta en un arroyo que baxa a dicho rio y queriendo proseguir al entero de dicho quarto de legua dijo el dicho encomendero se enterase hasia la parte del nortte frentte [89r] del dicho rio por no tener mas tierras suyas por dicho rumbo a la parte del poniente por tocarle a don Juan de Albornos su primo quien se allo pressente a esta medizion y en consideraçion de que les es de mas combeniençia a los dichos indios de que se les enttere sobre dicho rio por las buenas tierras que compreenden para sus sementeras mande aser una cruz en dicho sauze que cae juntto al dicho arroyo para que sirba de lindero y desde el mande se midiese dicho quarto de legua y las catorze cuerdas mas que faltaron en el primero y cojiendo el rumbo del nortte quarta al nordeste se midieron quarentta y quatro querdas de dichas sinquenta baras que asen el dicho quarto de legua y las dichas catorse cuerdas mas que terminaron en una loma baja adonde hise poner un palo de algarrobo cortado para que sirva de lindero. $Y$ cojiendo desde el rumbo del este quartta al nordeste se midieron otras dies y seis cuerdas de dichas sinquenta baras que terminaron sobre dicho rio y en un sause adonde mande poner una cruz para que sirva de lindero el qual cae juntto al passo de las carretas quedando dicho lindero a la partte del rio arriba quedando la poblasion antigua que fue del capitan Luis de [tachado: Albornos] Abreu su primer encomendero dentro de esta medizion y serca de dicho paso de carretas [89v] con lo qual quedaron enterados dichos indios de una legua de tierras en zircumferienzia que es lo que le corresponde al dicho cuarto de legua en quadro con lo qual quedaron medidas y amojonadas dichas tieras y en conformidad de su asignazion las declaro por tierras y pueblo de estos dichos yndios debaxo de los linderos referidos para que ussen de ellas en todo aquello que fuere de su utilidad y combeniencia en cumplimientto de leyes $\mathrm{y}$ hordenanças reales y en su virtud le di posesion a un yndio llamado don Bartholome como marido de doña Savina india curaca de este pueblo por si y en nombre de don Juan indio curaca su hijo menor y de los demas indios de esta encomienda que al presentte son y en adelante fueren la qual se la di en nombre de su magestad real actual corporal iure domini ber quasi cojiendole de la mano y paseandole por ellas y el dicho indio en señal de possesion arranco iervas e hizo otros actos de posesion y mando a los que presente estavan se saliesen de ellas y se las dejasen libres y dezembarasadas y de como tomo la dicha dicha possesion en dia claro y como a las nuebe del dia sin contradizion de persona alguna me pidio el dicho protector general en nombre de sus parttes se lo diese por testimonio. E yo el dicho capitan [90r] jues se lo doy en quantto puedo y a lugar de derecho de aver sido y passado como dicho es y en su comformidad mando a todas y qualesquier personas de quarquier estado calidad y condizion que sean no sean osados a quitar ni mober los dichos mojones ni inquietten ni perturben, a los dichos yndios de esta encomienda que al presentte son y adelantte fueren de la dicha posesion sin que primero sean oydos y por fuero y derecho bensidos so las penas dispuestas por derecho y de duzientos pesos mas aplicados camara de su magestad en que desde luego les doy por yncurssos y condenados lo contrario hasiendo. $Y$ el dicho encomendero dentro de ocho dias otorge instrumenttos publico y autentico antte el escrivano de cavildo para que en todos tiempos conste. Y por lo que toca a la capilla cumpla con 
la que tiene echa para que sirba a dichos yndios en la enseñansa y dotrina de nuestra santta fee catholica y que se puedan enterrar en ella los que murieren procurando la frecuenzia de missa los dias de fiesta como lo manda dicho señor vissitador general por su sentenzia y mando a los dichos indios e indias muchachos y muchachas de esta encomienda que luego se pueblen redusgan y mantengan en las dichas tierras sin salir de ellas mas que a las cosas y tiempos prevenidos por leyes y hordenansas reales. Y por lo que toca [90v] a los dies pesos que se mandan dar a los indios que an servido al dicho encomendero y seis a la india Bernita y dos a Bernarda Barthola y Anttonia aviendo comparezido antte mi y dicho protector dijeron averlos rezevidos de mano de su encomendero y que estavan contentos y pagados de ellos y en su comformidad le doy por libre de este cargo y remitase testimonio a costa del dicho encomendero a dicho señor oydor $\mathrm{y}$ vissitador general y para que conste lo firme con dicho protetor general y encomendero por antte mi y testigos a falta de escrivano siendolo presentes don Juan de Albornos y don Rodrigo de Albornos y Juan de Herrera Ayanume, que lo firmo el que supo en este papel comun a falta del sellado doy fee. Don Manuel de Zevallos Netto y Estrada. Juan Lopes de Fuentte Seca. Doctor Cristobal Pisarro de Albornos. Don Juan de Albornos. Don Rodrigo de Albornos.

[Al margen: Asignazion de tierras a los indios de la encomienda del capitan Francisco de Molina Navarrete]

En la estancia del capitan Francisco de Molina Navarrette llamada la cañada del cavilldo juridicion de la ciudad de Cordova tres leguas poco mas o menos de ella en veintte y tres dias del mes de febrero de mill y seissienttos y nobentta y quatro años yo el capitan don Manuel de Zevallos Netto y Estrada alguasil mayor y jues de comission nombrado por el señor doctor don Anttonio Martines Luxan de Bargas del consejo de su magestad su [91r] oydor mas antiguo de la real audienzia de la ciudad de La Platta y vissitador general de esta provincia del Tucuman por expesial comission del Rey nuestro señor para la execusion de las sentensias dadas a los bezinos encomenderos de esta juridizion y por lo que toca a la proveida contra el dicho capitan Francisco de Molina Navarrette en dicha ciudad de Cordova en dies y seis dias del mes de abril prossimo passado de mill y seiscienttos y nobentta y tres vine a esta dicha estançia con asistencia del capitan Juan Lopes de Fuentte Seca rexidor y protector general de los naturales y hizimos reconosimientto y vista de ojos de las tierras en que se combinieron le diesen a dichos indios los herederos del capitan don Juan de Avila y Zaratte difuntto y el dicho encomendero por si y en nombre de el capitan Fransisco de Molina su padre difuntto su primer encomendero por autto que en dicha razon proveyo dicho señor oydor y vissitador general las quales caen en la dicha cañada que llaman del cavilldo entre la estansia que al presentte tiene poblada el dicho encomendero quedando esta por la partte de avajo y por la partte de cañada arriba esta poblada doña Maria de Avila y Zaratte mujer de Diego Gutieres de las Nieves y en atension de que son frutiferas y con el agua sufisientte mande se midiesse y [91v] amojonasse el cuartto de legua en quadro que se les manda dar en atension de ser quatro los indios de esta encomienda y en su comformidad hize medir un cordel de cañamo de sinquentta baras y desde el pie de una loma baja que es la que baxa de las cassas que al presente tienen pobladas don Juan de Zaratte y la dicha doña Maria de Zaratte su hermana y mujer del dicho Diego Gutierres de las Niebes que la dicha loma corre cañada avajo azia las cassas y tierras del dicho encomendero y esta la dicha loma entre la dicha cañada y otra que cae para la parte del orientte y puesto al pie de dicha loma y entre las dos cañadas mande poner un monton de piedras para que sirva de lindero y zentro de esta medizion y cojiendo desde el [repetido: el] rumbo del sur quartta al sudueste se midieron quinze querdas de dichas sinquenta baras que asen medio quartto de legua que son las tierras que dan los herederos del capitan don Juan de Avila y Zaratte difuntto en conformidad de lo proveydo por dicho señor oydor y visitador general al escripto de combenio que por los intteresados se le presentto (que mando se acumule a esta asignacion) el qual dicho medio quartto de legua termino por juntto al rancho de Pasqual indio quedando el dicho rancho y 
poblasion que tiene el dicho indio en las tierras que quedan [92r] a la dicha doña Maria de Avila y Zaratte y sobre el dicho lindero de esta medizion por la partte de arriba y cojiendo el rumbo del oeste cuartta al nordeste se subio sobre una loma que esta al pie de dicha cañada a la parte del ponientte y sobre dicha loma hise poner un montte de piedras para que sirva de lindero y cojiendo el rumbo del nortte quarta al nordeste hize medir treinta cuerdas de dichas sinquenta baras que son las que pertenesen al dicho quartto de legua en que queda incluydo el medio quartto de legua que por dicho conbenio da el dicho encomendero que termino en dicha cañada adonde mande poner otro monton de piedras para que sirva de lindero entre las tierras del dicho encomendero y estos dichos indios. Y cojiendo el rumbo del este quarta al sueste hize medir otras treinta querdas de dichas sinquenta baras con que quedo enterado el dicho quartto de legua y termino al pie de una loma que esta anttes de llegar a una cañada grande que llaman las chacaras viejas que caen a la partte del orientte adonde mande poner otro montton de piedras para, que sirva de lindero. $Y$ cojiendo desde el [repetido: el] rumbo del sur quartta al sudueste se midieron otras treinta querdas de dichas sinquenta baras que terminaron a la bajada de una loma que cae [92v] en frentte de las cassas que tiene pobladas dicho yndio y primer lindero de esta medizion en donde mande poner otro monton de piedras para que sirva de lindero. Con lo qual quedaron medidas y amojonadas [entrelíneas: las] dichas tierras de un quartto de legua en quadro en que queda incluido el arroyo que baja por dicha cañada con mas un ojo de agua que esta en dicha cañada al pie de un sause y serca del lindero de la partte de avajo y respecto de que de este dicho ojo de agua pende el sustento y riego de la estancia y chacaras del dicho encomendero y no hazerles falta, a los dichos yndios assi por tener la sufisientte en el arroyo de arriba sitado como por no poder con este regar para arriba declaro el dicho ojo de agua por comun para dicha estancia y tierras del dicho encomendero y de dichos indios en las tierras que assi les dejo señaladas sin que por ninguna de las parttes se pueda poner ni ponga impedimentto al usso de dicha agua y en comformidad de su asignacion las declaro por tierras y pueblo de estos dichos indios debajo de los linderos de suso referidos para que se pueblen en ellas y las usen en todo aquello que fuere de su utilidad y conbeniensia en cumplimientto de las leyes y hordenansas reales y en su comformidad le di posesion [93r] de dichas tierras a un indio llamado Pasqual de esta encomienda por si y en nombre de los demas indios de ella que al presentte son y adelantte fueren y se la di en nombre de su magestad actual corporal iure domini berquassi cojiendole de la mano y paseandole por ellas y el dicho yndio en señal de posesion arranco iervas tiro piedras e hizo otros actos de posesion y mando a los que presentte estavan se saliesen dellas y se las dejasen libres y desembarasadas y de como tomo la dicha posesion en dia claro y como a las sinco de la tarde me pidio el dicho yndio y el protector general en su nombre se lo diese por testimonio. E yo el dicho jues se lo doy en quanto puedo y a lugar de derecho de aver sido y passado como dicho es y en su comformidad mando a todas y qualesquier personas de qualquier estado calidad y condizion que sean no sean osados a quitar ni mover los dichos mojones ni inquietten ni perturben a los dichos yndios de esta encomienda que al presente son y adelantte fueren de la dicha posesion sin que primero sean oydos y por fuero y derecho bensidos so las penas dispuestas por derecho y de duzienttos pesos mas aplicados camara de su magestad en que desde luego les doy por yncurssos y con[93r]denados lo contrario haziendo y en quantto a la capilla cumpla el dicho encomendero con azerla dentro de las dichas tierras asignadas y en el termino de seis meses que corren desde oy dia de esta asignazion debajo de las penas contenidas en la hordenanza veinte. $Y$ assimismo mando a todos los indios e yndias muchachos y muchachas de esta encomienda que luego se pueblen y reduzgan en dichas tierras sin salir de ellas mas que a las cosas y tiempos prevenidos por leyes y hordenanzas reales fomentandoles a ellos el dicho encomendero sin ponerles ningun estorbo a ello anttes si formentandoles a ello como es de su obligazion. Lo qual aviendoseles echo notorio assi a dicho encomendero como a dichos indios dijeron que estan pronttos a cumplir con lo que se les manda. $Y$ en quantto a la paga de los ocho pesos que se les mandan dar a cada uno de los indios que le an servido y tres pesos a los dos 
reservados en atension de aver confesado en mi presensia el dicho protector y dichos yndios estar pagados cada uno de dicha cantidad por averlos resevido de mano de su encomendero en la dicha ciudad de Cordova al tiempo de la visita le declaro por libre de esta obligasion y remitasse testimonio [94r] a dicho señor oydor y vissitador general a costa del dicho encomendero otorgando instrumentto publico con las partes interesadas de dichas tierras antte el escrivano de cavildo dentro de ocho dias para que en todos tiempos conste assi lo provey y firme con las partes y testigos que se hallaron presenttes el capitan Bernardo de Zevallos. Tomas de las Casas y el alferez Ygnazio de Molina Navarrette a faltta de escrivano y en este papel comun a falta del sellado doy fee. Don Manuel de Zevallos Netto y Estrada. Juan Lopes de Fuentte Seca. Fransisco de Molina Navarrette. Testigo Bernardo de Zevallos. Testigo Ignaçio de Molina Navarrette testigo Pedro Thomas de las Cassas.

[Al margen: Auto hecho contra Geronimo Luxan]

En el balle de Calamuchita y estancia del capitan Juan Clementte de Ibaigorri juridision de la ciudad de Cordova quinze leguas de ella poco mas o menos en trese dias del mes de diziembre de mill y seissienttos y nobentta y tres años yo el capitan don Manuel de Zevallos Netto y Estrada alguasil mayor propietario y jues nombrado por el señor doctor don Anttonio Martines Luxan de Bargas del consejo de su magestad su oydor mas antiguo de la real audiencia de La Platta y vissitador general de esta provincia del Tucuman por expesi[94v]al comision del Rey nuestro señor, para la execucion de las sentensias dadas a los vesinos encomenderos de esta dicha juridision y por lo que toca a la proveida contra el alferes Geronimo Luxan en dicha ciudad de Cordova en quinse dias del mes de abril de este presentte año de nobentta y tres en atension de hallarme zerca de sus estancias mandando se le notifique al susodicho que dentro de un mes se aga vissita de ojos con assistencia del protector general de las tierras que se asignaren a los indios mocovies de su encomienda juntto a la estancia de Siton que estan distantes de este paraje allandose presentte el dicho encomendero a dicha dilixencia para reconoser si son bastantes y sufisientes y en parte comoda para que puedan sembrar y tener sus grangerias y en casso que las dichas tierras no sean correspondienttes y de utilidad les asignara otras el dicho encomendero por ser de su obligaçion para lo qual reduzira a las dichas tierras a los indios e indias muchachos y muchachas de esta encomienda y para la aberiguazion de si estan pagados de los ocho pesos a los barones y quatro a las mujeres en que fue condenado por dicha sentenzia por el tiempo que le an servido todo lo qual cumpla dentro del dicho termino pena de sinquentta pesos aplicados camara de su magestad y con apersevimientto que el dicho termino passado reservo proveer lo demas que combenga lo qual [95r] se le notifique por mi dicho jues assi lo provey y firme por antte mi y testigos a falta de escribano. Don Manuel de Zevallos Netto y Estrada. Testigo Juan Lopez de Fuentte Seca Testigo Clemente de Otañes.

[Al margen: Notificacion]

Luego incontinenti en el dicho [entrelíneas: dia] mes y año arriba dichos yo el dicho jues notifique el autto de susso al alferes Geronimo Luxan de Medina quien dijo lo oya y que cumpliria con lo que se le manda y lo firmo conmigo. Don Manuel de Zevallos Netto y Estrada. Geronimo Luxan de Medina.

[Al margen: Reconozimiento de las tierras de los indios mocobies del alferes Geronimo Lujan]

En la estançia de doña Theresa Jaime de Zevallos llamada San Juan de Buena Benttura juridizion de la ciudad de Cordova [entrelíneas: cinco leguas poco mas de la dicha ciudad] en veintte y dos dias del mes de febrero de mill y seissienttos y nobentta y quatro años yo el capitan don Manuel de Zevallos alguazil mayor y jues nombrado por el dicho señor oydor y vissitador general en cumplimientto del autto por mi proveido en trese dias del mes de diziembre prosimo passado de nobenta y tres vine a esta dicha estanzia con asistencia del capitan don Juan Lopes de Fuentte 
Seca rejidor y protector general de los naturales para el reconosimientto de las dichas tierras que se asignaron a los indios mocobies de la encomienda del alferes Geronimo Lujan por el alferes Migel de Heredia su primer encomendero y aviendose echo vissita de ojos de ellas con asistensias de el dicho encomendero y de los testigos de iusso [95v] escriptos en atension de que las hallamos sin agua y que no son bastanttes por no tener señalado mas que dos quadras de ancho y quatro quadras de largo poco mas o menos segun reconosimos y nos ymformaron y tenerlas despobladas los dichos indios las declaro que no son bastantes ni sufisienttes y en su conformidad y en cumplimiento de lo mandado por dicho señor vissitador general por la zentensia de la vissita de estos yndios mando se le notifique al dicho encomendero les asigne otras tierras de un quartto de legua en quadro en consideracion de ser tres los indios de esta encomienda llamados Diego Geronimo y Fransisco que se hallaron presenttes y que sean frutiferas y en partte comoda con el agua sufisientte para que puedan sembrar y tener sus grangerias y aprovechamienttos para la paga de tributos a que estan obligados lo qual cumpla el dicho encomendero dentro de quinze dias primeros siguienttes dando razon donde las señala con apersevimientto que el dicho termino passado reservo probeer lo mas conbenientte en utilidad de dichos yndios y en quantto a los ocho pesos mandados pagar al indio Fransisco por el agravio de los azottes y los ocho pesos a [96r] cada uno de los indios que le an servido y quatro a cada una de las indias en atension de que aviendolos llamado a mi presensia y de dicho protector general y aver confesado los tienen resevidos de mano del dicho su encomendero se declaro por libre de este cargo y assi lo probey y firme por antte mi y testigos a faltta de escrivano siendolos presenttes a todo lo referido el sargentto mayor Fransisco de Ledesma y el capitan Thomas de Ledesma doy fee. Don Manuel de Zevallos Netto y Estrada. Juan Lopes de Fuentte Seca. Testigo Fransisco de Ledesma. Testigo Thomas de Ledesma.

[Al margen: Notificacion]

Luego incontinenti en el dicho paraje dicho dia mes y año arriba dichos yo el dicho jues de comision ley y notifique el autto de suso por mi proveydo al alferes Geronimo de Luxan bezino encomendero en su persona que dijo lo oya y firmo conmigo y testigos que presentes doy fee don Manuel de Zevallos Netto y Estrada. Geronimo de Luxan. Testigo Thomas de Ledesma testigo [entrelíneas: Francisco de Ledesma]

[Al margen: Asignacion de tierras a los indios de Geronimo Luxan]

En la estancia del alferes Geronimo Luxan de Medina llamada San Anttonio juridizion de la ciudad de Cordova dies y seis leguas de ella poco mas o menos en primero dia del mes de abril de mill y seissienttos y nobentta y quatro yo el capitan don Manuel de Zevallos Netto y Estrada alguazil mayor de su magestad y jues de comission nombrado [96v] por el señor doctor don Anttonio Martines Luxan de Balgas del consexo de su magestad su oydor mas antiguo de la real audiencia de la ciudad de La Plata y vissitador general de esta provincia del Tucuman por expesial comission del Rey nuestro señor para la execusion de las sentensias dadas a los bezinos encomenderos de esta juridizion y por lo que toca a la pronunciada contra el dicho alferes Geronimo Luxan en cumplimientto del autto por mi proveydo en esta rason en veintte y dos dias del mes de febrero de este presente año en que declare no ser bastantes ni sufisienttes las tierras que a los indios de esta encomienda se les avia señalado por el alferes Migel de Heredia difuntto su primer encomendero como consta de la dilixencia vine a esta dicha su estançia con asistenzia del capitan Juan Lopes de Fuentte Seca rexidor y protector general de los naturales y hizimos reconozimientto y vista de ojos de las tierras que [testado: asigna] el dicho encomendero las quales en atenzion de que son frutiferas y con el agua sufizientte y distanttes de las cassas del dicho encomendero las ube por asinadas y en su comformidad mando se mida y amojone un quar [97r]tto de legua en quadro para [entrelíneas: cuio] cumplimientto hize medir un cordel de cañamo de sinquenttas baras y puestos en un arroyo que vaja de la sierra de ponientte a orientte 
a la estançia del ayudantte general Manuel de Rivera y se incorpora con el arroyo [entrelíneas: que baja de Soconcho puesto sobre dicho aroyo] juntto a un arbol de molle hize poner un monton de piedras por ser el lindero que divide las tierras del dicho encomendero y las del dicho Manuel de Rivera y Nicolas de Baysa su suegro. Y desde el dicho montton de piedras cojiendo el rumbo del nortte cuartta al noroeste se midieron quinze cuerdas de dichas sinquentta baras que terminaron sobre una loma altta adonde hize poner un montton de piedras, para que sirva de lindero y bolbiendo a dicho arroyo y primer lindero de esta medizion cojiendo el rumbo del sur quartta al sueste hize medir otras quinze cuerdas de dichas sinquentta baras que terminaron sobre una loma altta que esta juntto a un arroyo y quebrada honda y sobre ella mande poner otro montton de piedras para que sirva de lindero. Y cojiendo desde el rumbo del oeste quartta al suduestte hize medir treinta querdas de dichas sinquentta baras que azen el dicho quartto de legua que terminaron por dicho rumbo a la cayda de una loma altta adonde hize poner otro monton de piedras [97v] para que sirva de lindero. Y cojiendo desde el rumbo del nortte quartta al nordeste hize medir otras treinta cuerdas de dichas sinquentta baras las quales terminaron sobre una loma altta quedando por este rumbo dentro de esta medizion dos arroyos y sobre dicha loma altta hize poner otro monton de piedras para que sirva de lindero. Con lo qual quedaron medidas y amojonadas las dichas tierras de un quartto de legua en quadro y en comformidad de su asignacion las declaro por tierras y pueblo de estos dichos indios debajo de los linderos referidos para que ussen de ellas en todo aquello que fuere de su utilidad y conbeniencia en cumplimientto de leyes y hordenansas reales y en su virtud le di possesion de dichas tierras a un indio, llamado Geronimo de esta encomienda por si y en nombre de los demas indios de ella que son y en adelantte fueren la qual se la di en nombre de su magestad real actual corporal iure domini bel quassi cojiendole de la mano y paseandole por ellas y el dicho indio en señal de posesion arranco iervas e hizo otros actos de posesion y dijo a los que presentte estavan se saliesen de ellas y se las dejasen libres y desembarasadas y de como tomo la dicha posesion en [98r] dia claro como a las onse de la mañana y sin contradision de persona alguna me pidio el dicho protector general en nombre de sus partes se lo diese por testimonio. E yo el dicho jues se lo doy en quantto puedo y a lugar de derecho de aver sido y passado como dicho es y en su [tachado: cumplimientto] comformidad mando a todas y qualesquier personas de qualquier estado calidad y condizion que sean no sean ossados a quitar ni mober los dichos mojones ni inquieten ni perturben a los dichos indios de esta encomienda que al presentte son y en adelante fueren de la dicha posesion sin que primero sean oydos y por fuero y derecho bensidos so las penas dispuestas por derecho y de duzienttos pesos mas aplicados camara de su magestad en que desde luego les doy por incurssos y condenados lo contrario hasiendo. $Y$ el dicho encomendero otorgue, instrumenttos publico dentro de ocho dias antte el escrivano de cavildo para que en todos tiempos conste. Y por lo que toca a la capilla cumpla el dicho encomendero con azerla dentro de seis meses que corran desde oy dia de la fecha de esta asignasion so las penas dispuestas por la hordenansa beintte de esta provincia. Y mando a los dichos [98v] indios e indias muchachos y muchachas de esta encomienda que luego se pueblen y redusgan y mantengan en las dichas tierras sin salir de ellas mas que a las cosas y tiempos prevenidos por leyes y hordenansas reales y remitasse testimonio al dicho señor oydor y vissitador general a costa de dicho encomendero y para que conste lo firme con el dicho protector general y encomendero por antte mi y testigos a faltta de escrivano siendolo presenttes don Fransisco Simon de Zevallos. Y Andres Benites en este papel comun a faltta del sellado doy fee. Don Manuel de Zevallos Netto y Estrada. Juan Lopes de Fuentte Seca. Geronimo Luxan. Don Fransisco Simon de Sevallos Netto y Estrada. testigo Andres Benites.

[Al margen: Auto]

En la ciudad de Cordova provincia del Tucuman en veinte dias del mes de abril de mill y seiscientos y nobentta y cuatro años el capital don Manuel de Zevallos Neto y Estrada alguazil 
maior de esta ciudad y juez de comision nombrado por el señor dotor don Antonio Martinez Luxan de Vargas del consexo de su magestad su oydor mas antiguo de la real audiencia de La Plata y visitador general en esta provincia por expecial comision de su magestad para la execuzion de las sentencias dadas por dicho señor oydor y visitador en la que hizo de las encomiendas para la adjudicazion y [99r] señalamiento de tierra que los vezinos encomenderos se les mando diesen a sus indios encomendados y capillas que se les mando edificar para la zelebrazion de los divinos oficios en el termino que en dichas sentencias se prebiene, dijo que por cuanto en cumplimiento de dicha comision a recorrido la jurisdizion y conforme el señalamiento que se previene a fecho hazer la adjudicazion de tierras a los indios y al tiempo della les mando y notifico a los vezinos encomenderos viniesen a otorgar escriptura cada uno de las tierras que havia adjudicado y dado a sus indios para que sea mas conforme a derecho y el de dichos indios constez[?] con lo cual no an cumplido y prezisa el dar cuentta de lo obrado en todo al dicho señor oydor y visitador general con testimonio de todos los auttos que tabien se an de sacar a costa de los dichos encomenderos por la presente ordena y manda que el presente escrivano aperziva y notifique a los dichos encomenderos comparezcan a otorgar las dichas escripturas a que son obligados y se les estta mandado lo cual cumplan pena de veinte pesos mitad camara de su magestad y gastos de justicia con aperzevimientto que de no hazerlo dentro de terzero dia se remitiran los autos que pide prezision y se les sacara dicha pena de mas a mas tendran la que dicho señor oydor y visitador general les pusiere por la inobedienzia y que por ella no vaya el testimonio como debe y para el paguen las costas y prorrateado asi lo probeyo mando y firmo en este papel comun a falta de sellado. Don Manuel de Zevallos Neto y Estrada. Ante mi don Luis Izquierdo de Guadalupe escrivano publico y de cavildo.

[Al margen; Notificaciones]

En la [99v] dicha ciudad en el dicho dia mes y año arriba dichos yo el presente escrivano notifique al capitan don Christoval Pizarro de Albornoz, Pedro Dias, Francisco de Molina que estaban en el pueblo y haviendolo oydo y entendido vinieron y otorgaron las escripturas de las tierras que dieron a sus indios y otorgaron antes de esto escriptura Miguel Moyano y don Sebastian de Carranza de ello doy fee y lo firme. Don Luis Izquierdo de Guadalupe escrivano publico y de cavildo. Enmendado $=$ veinte redu $=\mathrm{y}$ me $=$ que $=$ tter $=$ entrerrenglones $=$ mandado $=$ les $=$ amparo $=$ indios $=$ declaro su madre llamada Isabel $\mathrm{su}=$ dicha $=$ mill $=$ en ella $=$ que naze de dicho parage de las lagunas $\mathrm{y}$ corre $=\mathrm{n}=\mathrm{su}=\mathrm{en}=$ confesado $=$ hija $=$ persona $=\mathrm{y}$ estando presente dicho señor alcalde dijo = que en virtud de lo respondido por dicho administrador haze nombramiento $=$ de suso $=$ de la plata visitador general desta provincia $=\mathrm{se}=\mathrm{dicho}=\mathrm{su}=\mathrm{las}=\mathrm{dia}=$ zinco leguas poco mas o menos de la dicha ciudad $=$ que vaja de Soconcho puesto sobre dicho arroyo $=$ valen $=$ testigo $=\mathrm{de}=\mathrm{va}=\mathrm{de}=$ llamado Matheo $=\mathrm{a}=$ convenido $=$ sauze $=\mathrm{da}=$ parte $=$ reduzion $\mathrm{lo}=\mathrm{q}=$ Alvornoz $=$ cumplimiento $=$ no vale $=$

Concuerda con los autos originales que en virtud de su comision que esta por caveza obro el capitan don Manuel de Zevallos Neto y Estrada los cuales son ziento y cuarenta y zinco fojas estan en mi poder y oficio que se me entregaron y dellos y con ellos corregido y conzertados a que el presente siendo testigos el capitan Juan Lopez de Fuenteseca protector general de los naturales Francisco Lopez de Fuenteseca y Francisco de Salaberria fecho en Cordova a treinta de abril de mil y seiscientos y nobenta y cuatro años ban en este papel comun por falta del de oficio. En fee dello lo signo y firmo

En testimonio de verdad

Luis Izquierdo de Guadalupe escrivano publico y de cavildo [rubricado]

Derechos cuatro reales [rúbrica del escribano] 


\section{BIBLIOGRAPHY}

Fuentes

Archivo General de la Nación Argentina, Sala IX, Legajo 31-7-8.

Archivo General de la Nación Argentina, Sala IX, Legajo 23-4-5.

Archivo y Biblioteca Nacionales de Bolivia, Audiencia de Charcas, serie Expedientes Coloniales, EC-1694-15.

Albeck, M. E. y Palomeque, S. (2009). Ocupación española de las tierras indígenas de la Puna y 'raya del Tucumán' durante el temprano período colonial. Memoria Americana. Cuadernos de Etnohistoria, (17), 173-212. Disponible en:

http://www.scielo.org.ar/scielo.php?script=sci_arttext\&pid=S1851-7512009000200002

Bixio, B. (2007). La visita del oidor Luxan de Vargas a la jurisdicción de Córdoba del Tucumán (1692-1693): práctica de la justicia y disputa de valores. Revista Española de Antropología Americana, XXXVII (2), 61-79. Disponible en:

http://revistas.ucm.es/index.php/REAA/article/view/REAA0707220061A

Bixio, B. (2009). Introducción: Notas de lectura de la Visita de Luxan de Vargas al Tucumán colonial. En B. Bixio (Dir.), C. González Navarro, R. Grana y V. Iarza, Visita a las encomiendas de indios de Córdoba, 1692-1693, Tomo I (pp. 7-40). Córdoba: Centro de Estudios Históricos Prof. Carlos S. Segreti.

Bixio, B. (Dir.), González Navarro, C., Grana, R., Iarza, V. (2009). Visita a las encomiendas de indios de Córdoba, 1692-1693. Córdoba: Centro de Estudios Históricos Prof. Carlos S. Segreti. 2 tomos. Edición revisada y ampliada en 2013.

Boixadós, R. (2002). Los pueblos de indios de La Rioja colonial. Tierra, trabajo y tributo en el siglo XVII. En J. Farberman y R. Gil Montero (Comps.), Los pueblos de indios del Tucumán colonial: pervivencia y desestructuración (pp. 15-57). Bernal: EdiUnju / Universidad Nacional de Quilmes Ediciones.

Boixadós, R. (2003). La visita de Luján de Vargas a las encomiendas riojanas (1693): comentarios, notas y lecturas posibles. En R. Boixadós y C. Zanolli, La visita de Luján de Vargas a las encomiendas de La Rioja y Jujuy (1693-1694) (pp. 21-40). Bernal: Universidad Nacional de Quilmes Editorial.

Boixadós, R. y Zanolli, C. (2003). La visita de Luján de Vargas a las encomiendas de La Rioja y Jujuy (1693-1694). Estudios preliminares y fuentes. Bernal: Universidad Nacional de Quilmes Editorial.

Castro Olañeta, I. (2007). Indios encomendados, indios registrados, indios omitidos por el visitador Luján de Vargas. Salta, Gobernación de Tucumán, siglo XVII. XI Jornadas Interescuelas / Departamentos de Historia. Tucumán: Universidad Nacional de Tucumán. Edición en CD.

Castro Olañeta, I. (2015a). El Oidor de Charcas, Antonio Martínez Luján de Vargas, y la nueva coyuntura de fines de siglo XVII en Tucumán. A propósito de los derechos a la tierra de los pueblos de indios. Memoria Americana. Cuadernos de Etnohistoria, XXIII (1), 39-67. Disponible en: 
http://www.scielo.org.ar/scielo.php?script=sci_arttext\&pid=S1851-37512015000100003

Castro Olañeta, I. (2015b). Encomiendas, pueblos de indios y tierras. Una revisión de la visita del Oidor Luján de Vargas a Córdoba del Tucumán (fines siglo XVII). Estudios del ISHiR, (12), 82-104. Disponible en:

http://revista.ishir-conicet.gov.ar/ojs/index.php/revistaISHIR/article/view/542

Castro Olañeta, I. (2017). La visita del Oidor Antonio Martínez Luján de Vargas a las encomiendas de Catamarca, Santiago del Estero y Salta (Gobernación del Tucumán, 1693-1694). Córdoba: Programa de Historia Regional Andina / Ferreyra Editor.

Doucet, G. (1980a). Los autos del visitador don Antonio Martínez Luján de Vargas. Revista de Historia del Derecho, (8), 123-153.

Doucet, G. (1980b). Introducción al estudio de la visita del oidor don Antonio Martínez Luján de Vargas a las encomiendas de indios del Tucumán. Boletín del Instituto de Historia Argentina y Americana Dr. Emilio Ravignani, (26), 205-246.

Doucet, G. (1986). Los réditos de Quilpo. Funcionamiento de una encomienda cordobesa a fines del siglo XVI (1595-1598). Jahrbuch für Geschichte Lateinamerikas, (23), 63-119.

Doucet, G. (1990). La encomienda de servicio personal en el Tucumán, bajo régimen legal: comentarios a las Ordenanzas de Gonzalo de Abreu. En A. Levaggi (Coord.), El aborigen y el derecho en el pasado y el presente (pp. 141-244). Buenos Aires: Universidad del Museo Social Argentino.

Farberman, J. (1991). Indígenas, encomenderos y mercaderes: los pueblos de indios santiagueños durante la visita de Luján de Vargas (1693). Anuario del IEHS, (6), 43-57.

Farberman, J. (2002). Feudatarios y tributarios a fines del siglo XVII. Tierra, tributo y servicio personal en la visita de Luján de Vargas a Santiago del Estero (1693). En J. Farberman y R. Gil Montero (Comps.), Los pueblos de indios del Tucumán colonial: pervivencia y desestructuración (pp. 59-90). Bernal: EdiUnju / Universidad Nacional de Quilmes Ediciones.

Farberman, J. y Boixadós, R. (2006). Sociedades indígenas y encomienda en el Tucumán colonial. Un análisis comparado de la visita de Luján de Vargas. Revista de Indias, (238), 601-628. Disponible en:

http://revistadeindias.revistas.csic.es/index.php/revistadeindias/article/view/319

González Navarro, C. (2008). Los pueblos de indios de la jurisdicción cordobesa a la luz de la visita de Antonio Martines Luxan de Vargas (1692-1693). En S. Mallo y B. Moreyra (Comps.), Miradas sobre la historia social en la Argentina en los comienzos del siglo XXI (pp. 185-213). Córdoba: Centro de Estudios Históricos Prof. Carlos S. Segreti / CEHAC - Universidad Nacional de La Plata. González Navarro, C. (2009a). Córdoba desde su fundación hasta la visita de Antonio Martines Luxan de Vargas. En B. Bixio (Dir.), C. González Navarro, R. Grana y V. Iarza, Visita a las encomiendas de indios de Córdoba, 1692-1693, Tomo I (pp. 67-114). Córdoba: Centro de Estudios Históricos Prof. Carlos S. Segreti.

González Navarro, C. (2009b). La incorporación de los indios desnaturalizados del valle Calchaquí y de la región del Chaco a la jurisdicción de Córdoba del Tucumán. Una mirada desde la Visita del oidor Antonio Martines Luxan de Vargas (1692-93). Jahrbuch für Geschichte Lateinamerikas, (46), 231-259. 
González Navarro, C. (2010). La tenencia colectiva de la tierra entre las poblaciones indígenas de Córdoba. Siglos XVI y XVII. En A. I. Ferreyra (Dir.), Cuestiones Agrarias Argentinas (pp. 19-52). Córdoba: Editorial Brujas.

González Navarro, C. (2015). Los indios desnaturalizados del valle calchaquí en Córdoba: de rebeldes a fieles soldados del pueblo de San Joseph de los Ranchos, siglos XVII y XVIII. En J. Salazar (Comp.), Condiciones de posibilidad de reproducción social en sociedades prehispánicas y coloniales tempranas en las sierras pampeanas (Argentina) (pp. 151-176). Córdoba: Centro de Estudios Históricos Prof. Carlos S. Segreti. Disponible en:

http://www.cehsegreti.org.ar/descargas/FILE_00000000_1446488051.pdf

Lorandi, A. M. (1988). El servicio personal como agente de desestructuración en el Tucumán colonial. Revista Andina, (1), 135-173.

Lorandi, A. M. (Comp.). (1997). El Tucumán colonial y Charcas. Buenos Aires: Facultad de Filosofía y Letras, Universidad de Buenos Aires. 2 vols.

Noli, E. (2003). Pueblos de indios, indios sin pueblos: los calchaquíes en la visita de Luján de Vargas de 1693 a San Miguel de Tucumán. Anales Nueva Época, (6), 329-363. Disponible en:

https://gupea.ub.gu.se/bitstream/2077/3249/1/anales_6_noli.pdf

Noli, E. (2009). Indianidad y mestizaje en el mundo rural del Tucumán colonial: la jurisdicción de San Miguel en un período de transición (fines del siglo XVII y comienzos del XVIII) (Tesis de Doctorado). Quilmes: Universidad Nacional de Quilmes.

Palomeque, S. (2000). El mundo indígena (siglos XVI-XVIII). En E. Tandeter (Dir.), Nueva Historia Argentina, Tomo II (pp. 87-143). Buenos Aires: Sudamericana.

Schibli, M. y Tell, S. (2015). Apropiaciones del territorio indígena en el siglo XVIII. El pueblo de San Joseph en Los Ranchos del Río Segundo (Ponencia inédita). XV Jornadas Interescuelas/ Departamentos de Historia. Universidad Nacional de la Patagonia San Juan Bosco, Comodoro Rivadavia.

Sica, G. (2006). Del Pukara al Pueblo de Indios. El proceso de construcción de la sociedad colonial en Jujuy, Argentina. Siglo XVII (Tesis de Doctorado). Facultad de Geografía e Historia, Universidad de Sevilla, Sevilla.

Sica, G. (2016). Procesos comunes y trayectorias diferentes en torno a las tierras de los Pueblos de Indios de Jujuy. Siglo XVI al XIX. Revista del Museo de Antropología, IX (2), 171-186. Disponible:

https://revistas.unc.edu.ar/index.php/antropologia/article/view/15891/16044

Tanodi, B. (2000). Documentos históricos. Normas de Transcripción y Publicación. Cuadernos de Historia. Serie Economía y Sociedad, (3), 259-270.

Rappaport, J. (2005 [1994]). Cumbe renaciente. Una historia etnográfica andina. Bogotá: Instituto Colombiano de Antropología e Historia.

Tell, S. (2011). Tierras y agua en disputa. Diferenciación de derechos y mediación de conflictos en los pueblos de indios de Córdoba. Río de la Plata (primera mitad del siglo XIX). Fronteras de la Historia, XVI (2), 416-442. Disponible en:

http://www.icanh.gov.co/recursos_user/documentos/editores/202/Fronteras_16_2/ Fronteras_16_2_05_articulo.pdf

Tell, S. (2012). Conflictos por tierras en los 'pueblos de indios' de Córdoba. El pueblo de San Marcos entre fines del siglo XVII y principios del siglo XIX". Andes. Antropología e Historia, XXIII (1), 71-103. Disponible en: 
http://www.scielo.org.ar/scielo.php?script=sci_arttext\&pid=S1668-80902012000100003

Tell, S. y Castro Olañeta, I. (2011). El registro y la historia de los pueblos de indios de Córdoba entre los siglos XVI y XIX. Revista del Museo de Antropología, IV (4), 235-248. Disponible en:

https://revistas.unc.edu.ar/index.php/antropologia/article/view/5484

Tell, S. y Castro Olañeta, I. (2016). Los pueblos de indios de Córdoba del Tucumán y el pacto colonial (Siglos XVII a XIX). Revista del Museo de Antropología, IX (2), 209-220. Disponible en:

https://revistas.unc.edu.ar/index.php/antropologia/article/view/15894

Zanolli, C. (2003). Análisis de la visita de Luján de Vargas a la jurisdicción de San Salvador de Jujuy (1694). En R. Boixadós y C. Zanolli, La visita de Luján de Vargas a las encomiendas de La Rioja y Jujuy (1693-1694) (pp. 41-63). Bernal, Argentina: Universidad Nacional de Quilmes Editorial.

Zelada, V. (2015). Desnaturalizados Calchaquíes en Córdoba a fines del siglo XVII. Estudios del ISHiR, (12), 105-132. Disponible en:

http://revista.ishir-conicet.gov.ar/ojs/index.php/revistaISHIR/article/view/543

Zelada, V. (2017). El mundo desnaturalizado del Calchaquí en las encomiendas y pueblos de indios de Córdoba entre fines del siglo XVII y principios del siglo XVIII (Tesis de Licenciatura). Facultad de Filosofía y Humanidades, Universidad Nacional de Córdoba, Córdoba.

\section{NOTES}

1. Agradezco a Silvia Palomeque por facilitarme generosamente una copia de este documento, que localizó hace algunos años y de cuya importancia nos alertó; a María Elizabeth Rustán y María de la Paz Moyano por su cuidadosa colaboración en la revisión de esta transcripción y a Isabel Castro Olañeta por su calificado asesoramiento tanto para la escritura del estudio introductorio como para la interpretación de abreviaturas y palabras de dificultosa lectura.

2. Están transcriptos y publicados los segmentos de la visita correspondientes a las jurisdicciones de Córdoba (Bixio et al. 2009), La Rioja y Jujuy (Boixadós y Zanolli 2003); Catamarca, Santiago del Estero y Salta (Castro Olañeta 2017); la visita de Tucumán ha sido transcripta por Noli (2009) en el Anexo de su tesis de doctorado, aún inédita. Entre los estudios sobre la visita a distintas jurisdicciones, además de los ya mencionados de Doucet, se cuentan Bixio (2007, 2009); Boixadós (2002, 2003); Castro Olañeta (2007, 2015a, 2015b); Farberman (1991, 2002); Farberman y Boixados (2006); González Navarro (2008, 2009a, 2009b); Noli (2003, 2009); Sica (2006, 2016); Zanolli (2003).

3. Luján de Vargas había visitado un total de 36 encomiendas en la jurisdicción de Córdoba.

4. En ellas podían tener parcelas asignadas informalmente, pero en muchos casos ni siquiera las cultivaban, puesto que el encomendero los proveía de alimentos (Boixadós 2003).

5. Cuando se reconocieron tierras escrituradas previamente, se insertó traslado o copia de la escritura dentro de los autos.

6. Dentro de esta línea, consultan el manuscrito cuya transcripción incluimos aquí Castro Olañeta (2015a, 2015b) y Zelada $(2015,2017)$.

7. Archivo General de la Nación Argentina, Sala IX, 31-7-8, fs. 27v-28r.

8. Esa versión y la incluida en la copia de los autos de Manuel de Ceballos fueron transcriptas y publicadas como Anexo en Tell (2012), donde se estudia este conflicto.

9. Archivo General de la Nación Argentina, Sala IX, 23-4-5, f. 34v.

10. Este caso también ha sido tratado por González Navarro (2015).

11. Estas normas se incluyen como Anexo en Tanodi (2000). 


\section{ABSTRACTS}

This article presents the transcript of the file made between 1693 and 1694 by the commissioned judge Manuel de Ceballos Neto y Estrada, in charge of executing the judgments against encomenderos of the jurisdiction of Córdoba dictated by the oidor Antonio Martínez Luján de Vargas, once he finished his visit to the Government of Tucuman, is presented in this article. The manuscript recorded the application of the sentences, which included the demarcation and allocation of common lands to the encomiendas of Indians who were still settled on their encomenderos' private lands; the recognition and possible extension of lands previously assigned; the recognition of the chapels sent to build in the villages; the adjustment and payment of debts to the Indians for unpaid labor concerts or compensation for mistreatment. The transcription of the manuscript is preceded by an introductory study that describes the location and characteristics of the document, its internal organization, the information that it contains, possibilities of use, and previous research about it. It particularly emphasizes its importance for the study of the land rights of the Indian peoples.

Se presenta la transcripción de los autos obrados entre 1693 y 1694 por el juez comisionado Manuel de Ceballos Neto y Estrada, encargado de ejecutar las sentencias contra encomenderos de la jurisdicción de Córdoba dictadas por el oidor Antonio Martínez Luján de Vargas, una vez finalizada su visita a la Gobernación del Tucumán. En los autos se registró el proceso de ejecución de las sentencias, que incluyeron el deslinde, amojonamiento y asignación de tierras de reducción a encomiendas de indios que aún estaban asentadas en tierras privadas de sus encomenderos; el reconocimiento y eventual ampliación de tierras asignadas previamente; el reconocimiento de las capillas mandadas a edificar en los pueblos; el ajuste y liquidación de deudas a los indios por conciertos no remunerados o indemnización por malos tratos. La transcripción del manuscrito está precedida por un estudio introductorio que describe localización y características del documento, su organización interna, información que contiene, posibilidades de uso y relacionamiento del mismo, e investigaciones previas que lo abordaron. Destaca particularmente su importancia para el estudio de los derechos de tierras de los pueblos de reducción.

\section{INDEX}

Keywords: Lands, inspection, encomienda, conciertos, Indian peoples

Palabras claves: Tierras, visita, encomienda, conciertos, pueblos de indios

\section{AUTHOR}

\section{SONIA TELL}

Instituto de Humanidades, Universidad Nacional de Córdoba - Consejo Nacional de Investigaciones Científicas y Técnicas, Argentina

Correo electrónico: sotell@ffyh.unc.edu.ar 